Nevada

Environmental

Restoration

Project

\title{
Underground Test Area Quality Assurance Project Plan Nevada National Security Site, Nevada
}

Controlled Copy No.:

Revision No.: 0

May 2011

Approved for public release; further dissemination unlimited.

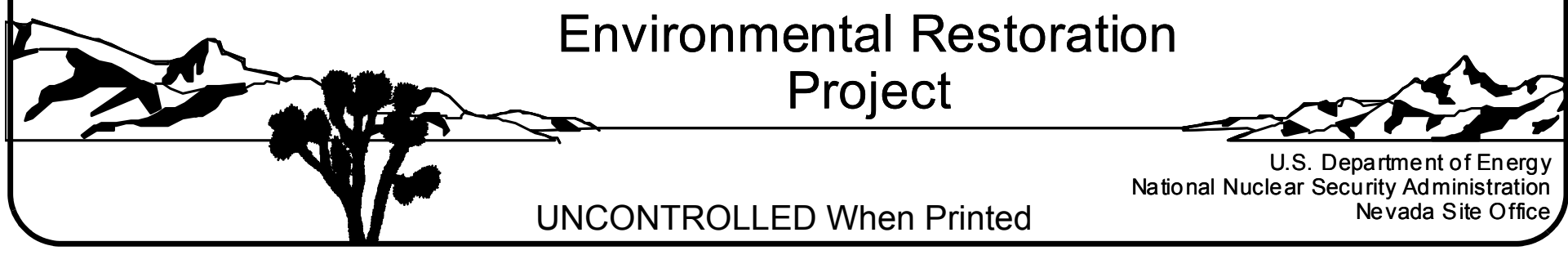


Available for sale to the public from:

U.S. Department of Commerce

National Technical Information Service

5301 Shawnee Road

Alexandria, VA 22312

Telephone: 800.553 .6847

Fax: 703.605.6900

E-mail: orders@ntis.gov

Online Ordering: http://www.ntis.gov/help/ordermethods.aspx

Available electronically at http://www.osti.gov/bridge

Available for a processing fee to U.S. Department of Energy and its contractors, in paper, from:

\section{U.S. Department of Energy}

Office of Scientific and Technical Information

P.O. Box 62

Oak Ridge, TN 37831-0062

Phone: 865.576 .8401

Fax: 865.576.5728

Email: reports@adonis.osti.gov

Reference herein to any specific commercial product, process, or service by trade name, trademark, manufacturer, or otherwise, does not necessarily constitute or imply its endorsement, recommendation, or favoring by the United States Government or any agency thereof or its contractors or subcontractors. 


\title{
UNDERGROUND TEST AREA QUALITY ASSURANCE PROJECT PLAN NEVADA NATIONAL SECURITY SITE, NEVADA
}

\author{
U.S. Department of Energy \\ National Nuclear Security Administration \\ Nevada Site Office \\ Las Vegas, Nevada
}

Controlled Copy No.:

Revision No.: 0

May 2011

Approved for public release; further dissemination unlimited.

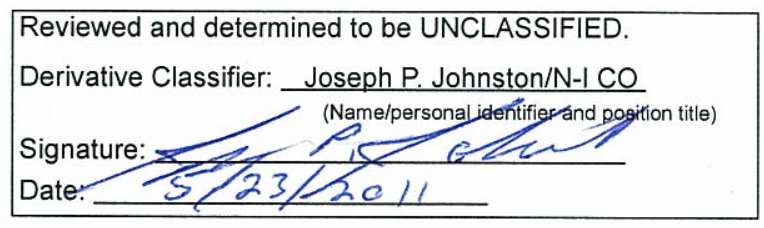

UNCONTROLLED When Printed 
UNDERGROUND TEST AREA

QUALITY ASSURANCE PROJECT PLAN

NEVADA NATIONAL SECURITY SITE, NEVADA

Approved by: Weebhen. With Date: $5 / 23 / 201$

Bill R. Wilborn

Federal Sub-Project Director

Underground Test Area Sub-Project

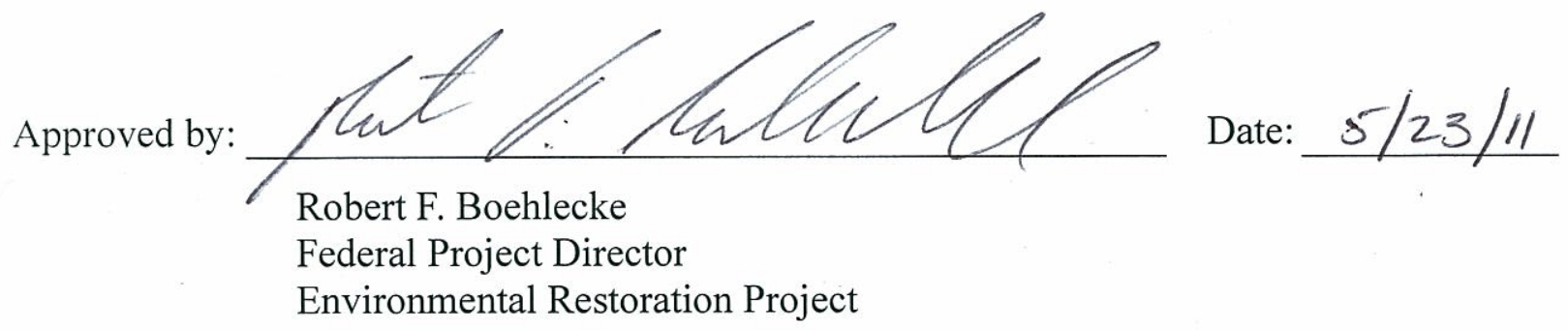

UNCONTROLLED When Printed 


\section{Table of Contents}

List of Figures $\mathrm{V}$

List of Tables vi

List of Acronyms and Abbreviations $\ldots \ldots \ldots \ldots \ldots \ldots \ldots \ldots \ldots \ldots \ldots \ldots \ldots \ldots \ldots \ldots \ldots$

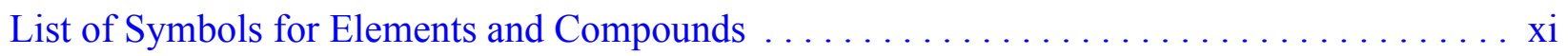

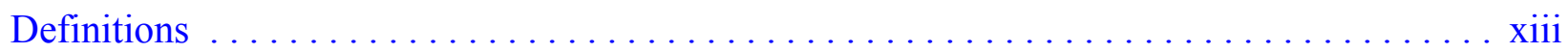

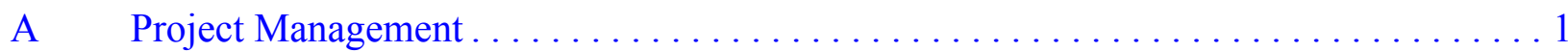

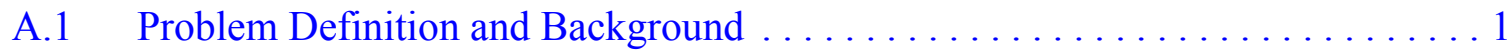

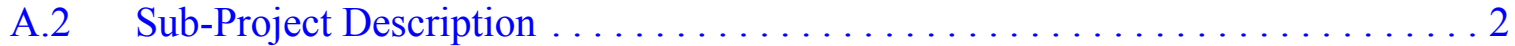

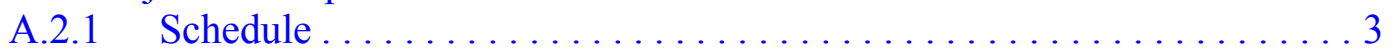

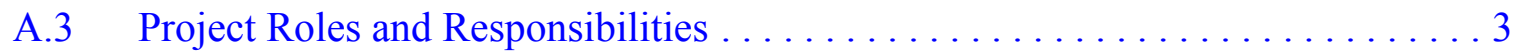

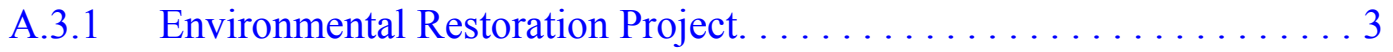

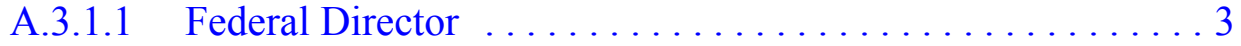

A.3.1.2 Federal Sub-Project Director $\ldots \ldots \ldots \ldots \ldots \ldots \ldots$

A.3.1.3 Federal Task Manager $\ldots \ldots \ldots \ldots \ldots \ldots \ldots \ldots \ldots$

A.3.2 Sub-Project Participants . . . . . . . . . . . . . . . . . 5

A.3.2.1 Desert Research Institute . . . . . . . . . . . . . . 5

A.3.2.2 Environmental Restoration Contractor ............6 6

A.3.2.3 Management and Operating Contractor ..........6 6

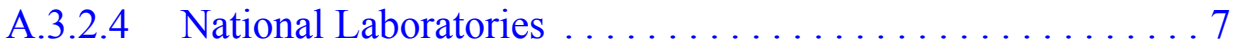

A.3.2.5 U.S. Geological Survey $\ldots \ldots \ldots \ldots \ldots \ldots \ldots \ldots \ldots$

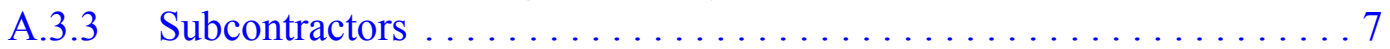

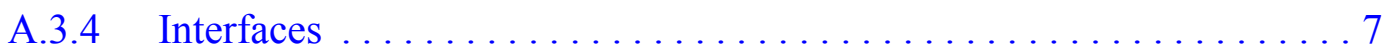

A.3.4.1 Contract Managers $\ldots \ldots \ldots \ldots \ldots \ldots \ldots \ldots \ldots \ldots$

A.3.4.2 CAU Leads .....................

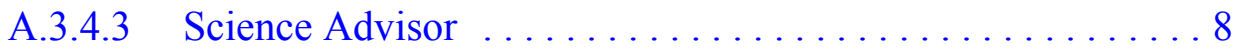

A.3.5 Committees.......................... 8

A.3.5.1 Technical Working Group $\ldots \ldots \ldots \ldots \ldots \ldots \ldots \ldots$

A.3.5.2 Pre-Emptive Review Committees . . . . . . . . . . . . 8

A.3.5.3 Topical Committees .................. 9

A.3.5.4 Drilling Advisory Teams $\ldots \ldots \ldots \ldots \ldots \ldots$

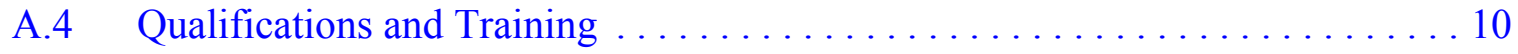

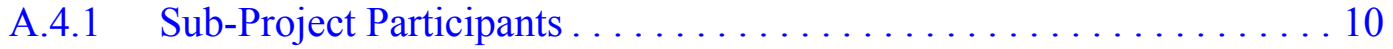

A.4.2 Subcontracts ........................... 10

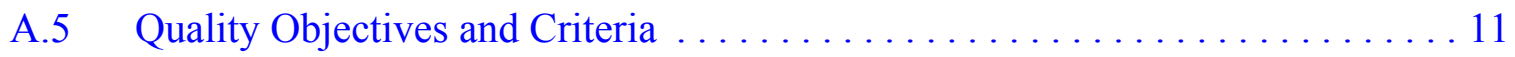

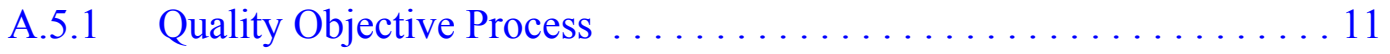

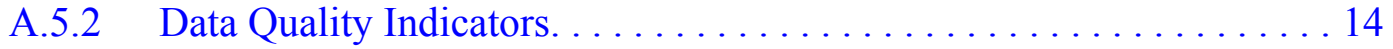

A.5.2.1 Precision ......................... 14

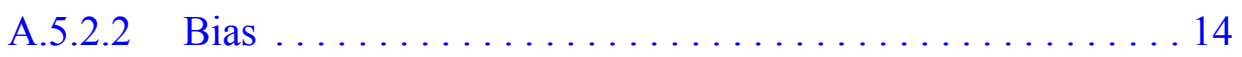

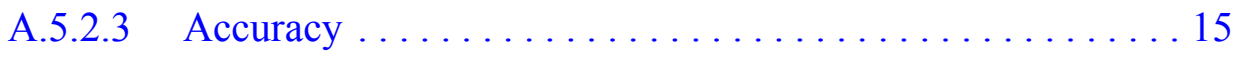




\section{Table of Contents (Continued)}

A.5.2.4 Representativeness .................. 15

A.5.2.5 Completeness ........................ 15

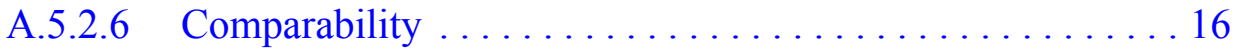

A.6 Document Control. ............................ 16

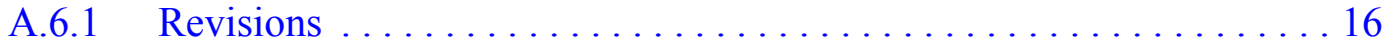

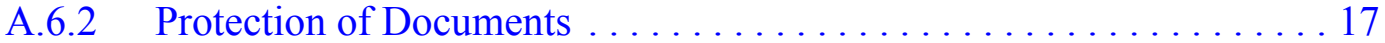

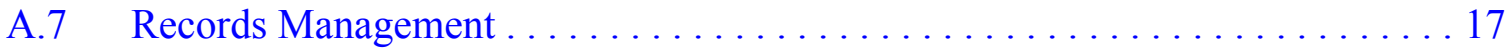

A.8 Data Management.............................. 19

A.8.1 Data Source Acceptance. . . . . . . . . . . . . . . . . . . . . . . 19

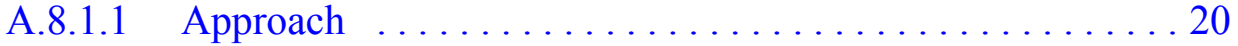

A.8.1.2 Documentation ....................... 20

A.8.1.3 Documentation Review ................. 21

A.8.2 Data Quality Evaluation ........................ 21

A.8.3 Data Transferability . . . . . . . . . . . . . . . . . . . . 21

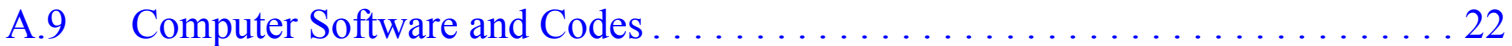

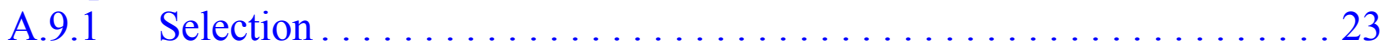

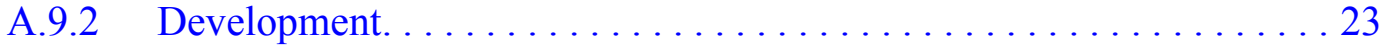

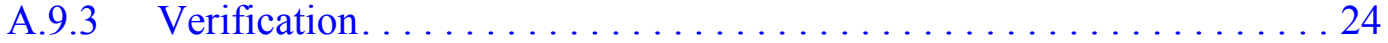

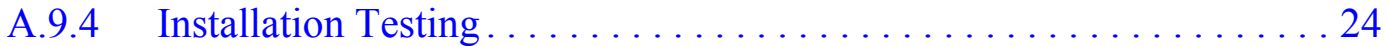

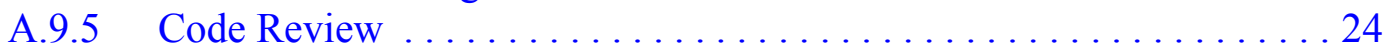

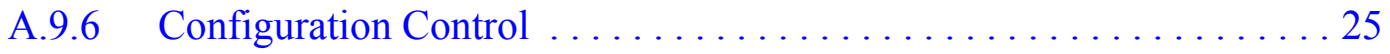

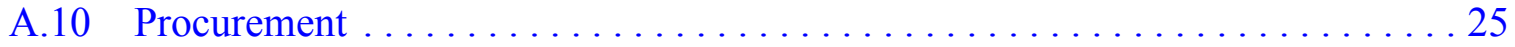

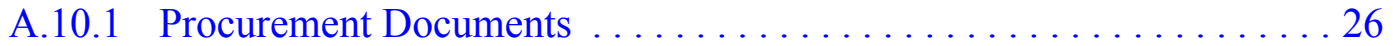

A.10.2 Instrument/Equipment Testing, and Inspection . . . . . . . . . 26

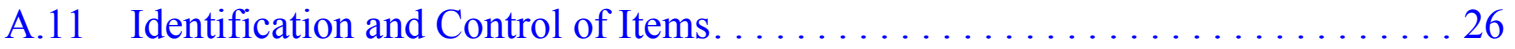

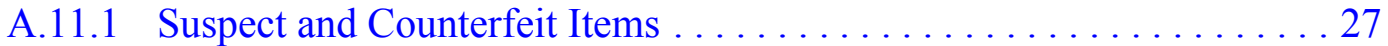

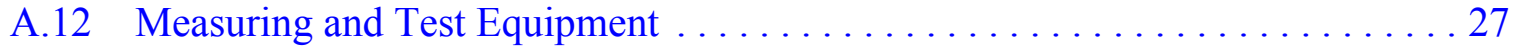

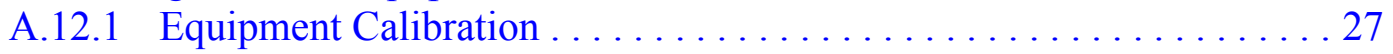

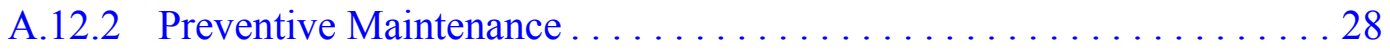

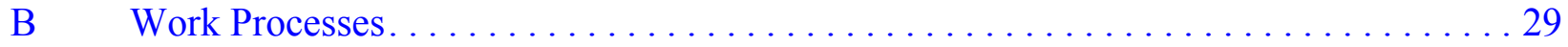

B.1 Field Activities . . . . . . . . . . . . . . . . . . . . . 29

B.1.1 Planning Documentation . . . . . . . . . . . . . . . . . 29

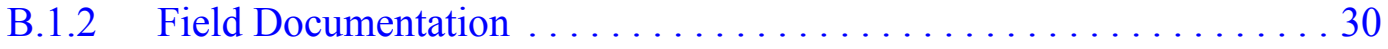

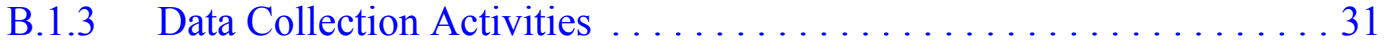

B.1.3.1 Well Drilling and Completion $\ldots \ldots \ldots \ldots \ldots \ldots \ldots \ldots$

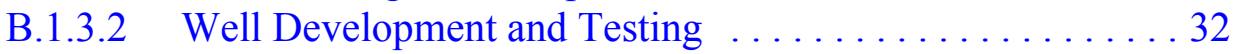

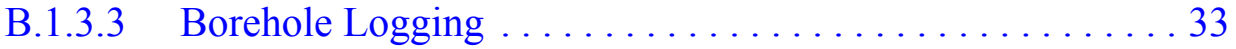

B.1.3.4 Water-Level Measurements . . . . . . . . . . . . 34

B.1.3.5 Water-Quality Measurements ................ 34 


\section{Table of Contents (Continued)}

B.1.3.6 Land Surveys, Surface Geophysics, and Geologic Mapping ......................... 34

B.1.3.7 Sample Collection ........................ 35

B.1.3.7.1 Sample Labels and Identification . . . . . . . . 35

B.1.3.7.2 Sample Handling . . . . . . . . . . . . . 36

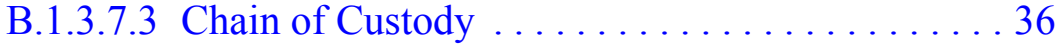

B.1.3.7.4 Field QC Samples $\ldots \ldots \ldots \ldots \ldots \ldots \ldots . \ldots 37$

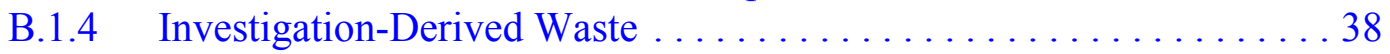

B.2 Laboratory Analyses.................................... 38

B.2.1 Sample Storage............................... 39

B.2.2 Laboratory Quality Control Samples .................... 39

B.2.2.1 Laboratory Control Samples .................... 39

B.2.2.2 Method Blanks ....................... 40

B.2.2.3 Laboratory Replicate Samples ................. 40

B.2.2.4 Matrix Spike Samples ..................... . 40

B.2.3 Performance Evaluation Programs ................. 40

B.2.3.1 Parameters with Established PEPs . . . . . . . . . . 40

B.2.3.2 Interlaboratory Comparisons $\ldots \ldots \ldots \ldots \ldots \ldots \ldots . . \ldots 1$

B.2.3.3 Data Evaluation ...................... 42

B.2.4 Analytical Data Documentation................... 42

B.2.5 Verification and Validation of Analytical Data .............. 42

B.2.5.1 Non-regulatory Data . . . . . . . . . . . . . . . . 43

B.2.5.2 Regulatory Data $\ldots \ldots \ldots \ldots \ldots \ldots \ldots \ldots \ldots \ldots \ldots$

B.3 Laboratory Studies . . . . . . . . . . . . . . . . . . . . . . . . 44

B.4 Non-direct Data. ................................. 44

B.5 Groundwater Flow and Transport Modeling $\ldots \ldots \ldots \ldots \ldots \ldots \ldots \ldots . \ldots 4$

B.5.1 Model Parameters........................... 46

B.5.1.1 Hydrostratigraphic Framework Model .............. 46

B.5.1.2 Hydrologic Data .......................... 46

B.5.1.3 Transport Parameters . . . . . . . . . . . . . . . . . 46

B.5.1.4 Source Term Data ......................... 48

B.5.2 Model Parameter Preparation..................... 48

B.5.3 Model Calibration. . . . . . . . . . . . . . . . . . . . . . . . 49

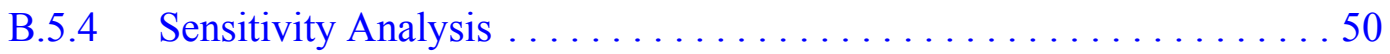

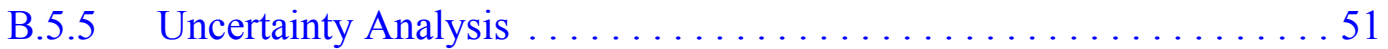

B.5.6 Contaminant Boundary Calculations .................. 52

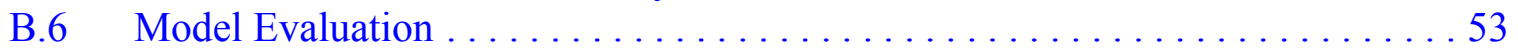

B.7 Configuration Control................................. 53

C Assessment and Oversight ............................... 54

C.1 Assessment ..................................... 54 


\section{Table of Contents (Continued)}

C.1.1 NDEP and NNSA/NSO Decision Points . . . . . . . . . . . . . . 54

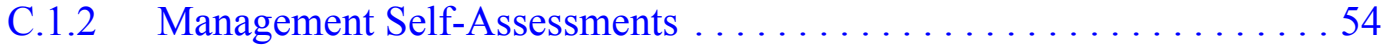

C.1.3 Oversight Assessments.......................... 55

C.2 Technical Reviews . . . . . . . . . . . . . . . . . . . . . 55

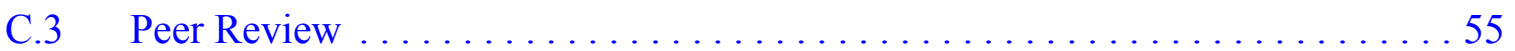

C.4 Document Review and Issuance. . . . . . . . . . . . . . . . . . . . 56

C.4.1 Input to Other Participant Documents $\ldots \ldots \ldots \ldots \ldots \ldots \ldots \ldots$

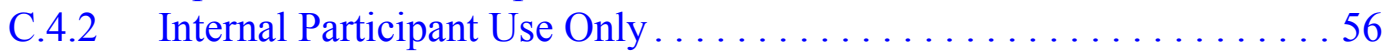

C.4.3 Internal Review . . . . . . . . . . . . . . . . . . . 57

C.4.4 External Review . . . . . . . . . . . . . . . . . . . . . . . 58

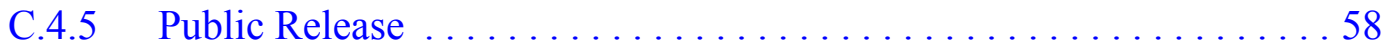

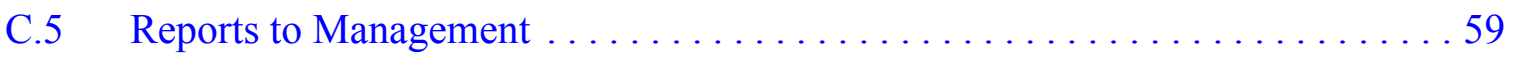

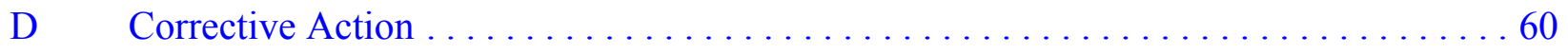

D.1 Stop Work Order. . . . . . . . . . . . . . . . . . . . . . . . 60

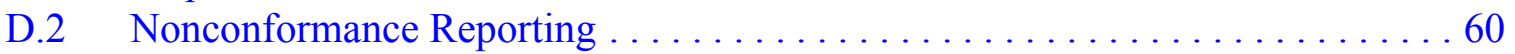

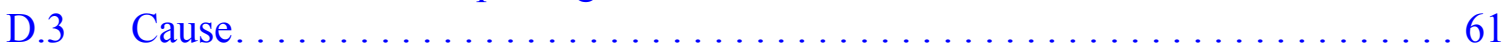

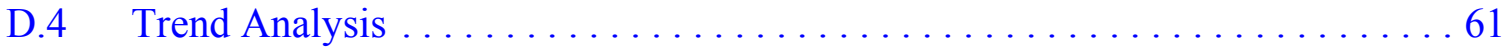

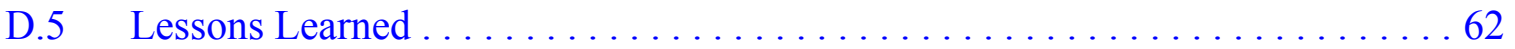

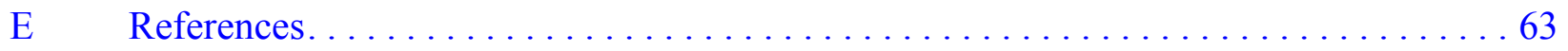

Attachment 1 - UGTA Field Measurements

Attachment 2 - Laboratory Analyses, Parameters, Methods, and Requirements 


\section{List of Figures}

Number

Title

Page

B-1 Groundwater Flow and Transport Modeling Parameters ............... 45

B-2 HFM Modeling Parameters and Process....................... 47 


\section{List of Tables}

Number

A-1

1-1
Title

Page

UGTA Field Measurements. . . . . . . . . . . . . . . . . . . 1-1

Groundwater Characterization Parameters . . . . . . . . . . . . . . 2-1

Radioisotopes Potentially Selected as Contaminants of Concern and Analyzed by a Certified Laboratory . . . . . . . . . . . . 2-4

Fluid Management Sample Analytes. . . . . . . . . . . . . . . . 2-5

Nonregulated Analytes Used for Estimating the Origin, Pathway, and Timescale of Groundwater Flow and Transport . . . . . . . . . . . . . 2-6 


\section{List of Acronyms and Abbreviations}

2-D Two dimensional

3-D Three dimensional

AMS Accelerator mass spectrometry

ASTM ASTM International

BHI Baker Hughes, Inc.

${ }^{\circ} \mathrm{C} \quad$ Degrees Celsius

CADD Corrective action decision document

CAI Corrective action investigation

CAIP Corrective action investigation plan

CAP Corrective action plan

CAU Corrective action unit

$\mathrm{cm} \quad$ Centimeter

COLOG Colog, Inc.

CR Closure report

DOE U.S. Department of Energy

DOECAP U.S. Department of Energy Consolidated Audit Program

DOT U.S. Department of Transportation

DQI Data quality indicator

DQO Data quality objective

DRI Desert Research Institute

DRS Document Review Sheet

EERF Eastern Environmental Radiation Facility

EPA U.S. Environmental Protection Agency

ER Environmental Restoration

ERA Environmental Resources Associates

ET Evapotranspiration 


\section{List of Acronyms and Abbreviations (Continued)}

FAWP Field activity work package

FFACO Federal Facility Agreement and Consent Order

$\mathrm{ft} \quad$ Foot

FY Fiscal year

gal Gallon

gpm Gallons per minute

GPO U.S. Government Printing Office

GS-MS Gas source-mass spectrometry

HASL Health and Safety Laboratory

HDPE High-density polyethylene

HFM Hydrostratigraphic framework model

HSU Hydrostratigraphic unit

IAEA International Atomic Energy Agency

IC Ion chromatography

ICP-AES Inductively coupled plasma-atomic emission spectrometry

ICP-MS Inductively coupled plasma-mass spectrometry

IRMS Isotope ratio mass spectrometry

$\mathrm{K}_{\mathrm{d}} \quad$ Distribution coefficient

L Liter

LANL Los Alamos National Laboratory

LCS Laboratory control sample

LiDAR Light Detection and Ranging

LLNL Lawrence Livermore National Laboratory

LQC Laboratory quality control

LSC Liquid scintillation counting

MAPEP Mixed Analyte Performance Evaluation Program 


\section{List of Acronyms and Abbreviations (Continued)}

\begin{tabular}{|c|c|}
\hline $\mathrm{M} \& \mathrm{O}$ & Management and operating \\
\hline M\&TE & Measuring and test equipment \\
\hline $\mathrm{mg} / \mathrm{L}$ & Milligrams per liter \\
\hline $\mathrm{mL}$ & Milliliter \\
\hline NA & Not available \\
\hline N/A & Not applicable \\
\hline NCR & Nonconformance report \\
\hline NDEP & Nevada Division of Environmental Protection \\
\hline NGMS & Noble gas mass spectrometry \\
\hline NIST & National Institute of Standards and Technology \\
\hline NNSA/NSO & $\begin{array}{l}\text { U.S. Department of Energy, National Nuclear Security Administration } \\
\text { Nevada Site Office }\end{array}$ \\
\hline NNSS & Nevada National Security Site \\
\hline NSF & National Science Foundation \\
\hline NSTec & National Security Technologies, LLC \\
\hline NTU & Nephelometric turbidity unit \\
\hline NWSC & Nevada Water Science Center \\
\hline $\mathrm{pCi} / \mathrm{L}$ & Picocuries per liter \\
\hline PEP & Performance evaluation program \\
\hline PEST & Parameter estimation software \\
\hline PIMMS & Plasma ionization multicollector mass spectrometer \\
\hline QA & Quality assurance \\
\hline QAPP & Quality Assurance Project Plan \\
\hline QC & Quality control \\
\hline QCCS & Quality control check standard \\
\hline RCRA & Resource Conservation and Recovery Act \\
\hline RE & Relative error \\
\hline
\end{tabular}




\section{List of Acronyms and Abbreviations (Continued)}

\begin{tabular}{|c|c|}
\hline REOP & Real Estate/Operations Permit \\
\hline RPD & Relative percent difference \\
\hline RST & Radiologic source term \\
\hline RTC & Resource Technology Corp. \\
\hline SBMS & Standards-Based Management System \\
\hline SDWA & Safe Drinking Water Act \\
\hline SI-MS & Stable isotope mass spectrometry \\
\hline SOP & Standard operating procedure \\
\hline SOW & Statement of work \\
\hline SWO & Stop work order \\
\hline TBD & To be determined \\
\hline TIMS & Thermal ionization mass spectrometry \\
\hline TIRP & Technical Information Review Panel \\
\hline TWG & Technical Working Group \\
\hline UNR & University of Nevada Reno \\
\hline UGTA & Underground Test Area \\
\hline USGS & U.S. Geological Survey \\
\hline XRD & X-ray diffraction \\
\hline $\mathrm{XRF}$ & X-ray fluorescence \\
\hline$\mu \mathrm{g} / \mathrm{L}$ & Micrograms per liter \\
\hline$\mu \mathrm{m}$ & Micrometer \\
\hline$\mu \mathrm{S}$ & Microsiemen \\
\hline$\mu \mathrm{S} / \mathrm{cm}$ & Microsiemens per centimeter \\
\hline
\end{tabular}




\section{List of Symbols for Elements and Compounds}

\begin{tabular}{|c|c|}
\hline $\mathrm{AgNO}_{3}$ & Silver nitrate \\
\hline $\mathrm{Am}$ & Americium \\
\hline $\mathrm{C}$ & Carbon \\
\hline $\mathrm{Cl}$ & Chlorine \\
\hline $\mathrm{Cm}$ & Curium \\
\hline Cs & Cesium \\
\hline DIC & Dissolved inorganic carbon \\
\hline DOC & Dissolved organic carbon \\
\hline $\mathrm{Eu}$ & Europium \\
\hline${ }^{2} \mathrm{H}$ & Deuterium \\
\hline${ }^{3} \mathrm{H}$ & Tritium \\
\hline $\mathrm{H}_{2} \mathrm{O}$ & Water \\
\hline $\mathrm{H}_{2} \mathrm{SO}_{4}$ & Sulfuric acid \\
\hline $\mathrm{HCl}$ & Hydrochloric acid \\
\hline $\mathrm{HgCl}_{2}$ & Mercury chloride \\
\hline $\mathrm{HNO}_{3}$ & Nitric acid \\
\hline I & Iodine \\
\hline $\mathrm{Kr}$ & Krypton \\
\hline $\mathrm{NaOH}$ & Sodium hydroxide \\
\hline $\mathrm{Ni}$ & Nickel \\
\hline $\mathrm{Np}$ & Neptunium \\
\hline $\mathrm{O}$ & Oxygen \\
\hline $\mathrm{Pu}$ & Plutonium \\
\hline $\mathrm{Rb}$ & Rubidium \\
\hline $\mathrm{S}$ & Sulfur \\
\hline
\end{tabular}




\section{List of Symbols for Elements and Compounds (Continued)}

$\begin{array}{ll}\mathrm{Sm} & \text { Samarium } \\ \mathrm{Sr} & \text { Strontium } \\ \mathrm{Tc} & \text { Technetium } \\ \text { TDIC } & \text { Total dissolved inorganic carbon } \\ \text { TDOC } & \text { Total dissolved organic carbon } \\ \text { Th } & \text { Thorium } \\ \text { TOC } & \text { Total organic carbon } \\ \text { U } & \text { Uranium } \\ \text { ZnAc } & \text { Zinc acetate } \\ \text { Zr } & \text { Zirconium }\end{array}$




\section{Definitions}

\section{Acceptance Criteria}

Specific limits placed on an item, process, or service defined in requirements documents (EPA, 2005).

\section{Assessment}

A review, evaluation, inspection, test, check, surveillance, or audit to determine and document whether items, processes, systems, or services meet specified requirements and perform effectively (NNSA/NSO, 2010).

\section{Calibration}

Comparison of a measurement standard, instrument, or item with a standard or instrument of higher accuracy to detect and quantify inaccuracies and to report or eliminate those inaccuracies by adjustments (EPA, 2005).

\section{Certification}

The process of testing and evaluating against specifications designed to document, verify, and recognize the competence of a person, organization, or other entity to perform a function or service, usually for a specified time (EPA, 2005).

\section{Contaminant Boundary}

A probabilistic model-forecast perimeter and a lower hydrostratigraphic unit boundary that delineates over 1,000 years the extent of radionuclide-contaminated groundwater from underground testing (FFACO, 1996; as amended).

\section{Corrective Action}

Action taken in response to an identified issue and intended to resolve the existing condition, introduce compensatory or remedial actions as necessary, and minimize the probability of a recurrence of the issue (NNSA/NSO, 2010).

\section{Data Quality Objectives}

Qualitative and quantitative statements derived from the data quality objective process. The DQOs can be used as the basis for establishing the quality and quantity of data needed to support decisions (EPA, 2005).

\section{Data Usability}

The result of verifying or determining that the quality of the data produced is adequate for its intended use (ASQ, 2004). 


\section{Definitions (Continued)}

\section{Deficiency}

An unauthorized deviation from acceptable procedures or practices, or a defect in an item (ASQ, 2004).

\section{Environmental Data}

Any measurements or information that describe environmental processes, locations, or conditions; ecological or health effects and consequences; or the performance of environmental technology. This includes information collected directly from measurements, produced from models, and compiled from other sources such as databases or the literature (EPA, 2005).

\section{Inspection}

An examination or measurement of an item or activity to verify conformance to specific requirements (EPA, 2005).

\section{Item}

An all-inclusive term used in place of any of the following: appurtenance, facility, sample, assembly, component, equipment, material, module, part, structure, subassembly, subsystem, system, unit, documented concepts, or data (ASQ, 2004).

\section{Management Assessment}

An introspective self-analysis performed by an organization (NNSA/NSO, 2010).

\section{Measuring and Test Equipment}

Measuring instrument, software, measurement standard, referenced material or auxiliary equipment, or combination thereof, to realize a measurement process. Such equipment may include tools, gauges, instruments, sampling devices, or systems used to calibrate, measure, gauge, test, or inspect to control or acquire data to verify conformance to specified requirements (ASQ, 2004).

\section{Method}

A body of procedures and techniques for performing an activity (e.g., sampling, chemical analysis, quantification) systematically presented in the order in which they are to be executed (EPA, 2005).

\section{Model}

A simplification of reality that is constructed to gain insights into select attributes of a physical, biological, economic, or social system. A format representation of the behavior of system processes, often in mathematical or statistical terms. The basis can also be physical or conceptual (EPA, 2009). 


\section{Definitions (Continued)}

\section{Model Evaluation}

The process used to determine whether a model and its results are of a quality sufficient to serve as the basis for a regulatory decision (EPA, 2009).

\section{Nonconformance}

A deficiency in characteristic, documentation, or procedure that renders the quality of an item or activity unacceptable or indeterminate; nonfulfillment of a specified requirement (EPA, 2005).

\section{Non-direct Data}

Data collected or generated outside the Sub-Project (EPA, 2002).

\section{Oversight Assessment}

An analysis or review of contractor programs, processes, or products conducted by U.S. Department of Energy, National Nuclear Security Administration Nevada Site Office federal staff (NNSA/NSO, 2010).

\section{Procedure}

A specified way to carry out an activity or process (ASQ, 2004).

\section{Quality}

Degree to which a set of inherent characteristics fulfills requirements. Quality may relate to a product or service that bears on its ability to meet the stated or implied needs and expectations of the user (ASQ, 2004).

\section{Quality Assurance}

Part of quality management focused on providing confidence that quality requirements will be fulfilled. Quality assurance may include management activities involving planning, implementation assessment, reporting, and quality improvement to ensure that a process, item, or service is of the type and quality needed and expected by the customer (ASQ, 2004).

\section{Quality Control}

Part of quality management focused on fulfilling quality requirements. Quality control includes technical activities that measure the attributes and performance of a process, item, or service against defined standards to verify that they meet the stated requirements established by the customer, operational techniques, and activities that are used to fulfill requirements for quality (ASQ, 2004). 


\section{Definitions (Continued)}

\section{Readiness Review}

A systematic, documented review of the readiness for startup or continued use of a facility, process, or activity. Readiness reviews are typically conducted before proceeding beyond project milestones and before instituting a major phase of work (ASQ, 2004).

\section{Record}

Book, paper, map, photograph, machine-readable material (i.e., electronic data, email), or other documentary material, regardless of physical form or characteristics, made or received by an agency of the United States government under federal law or in connection with the transaction of public business, and preserved or deemed appropriate for preservation by that agency or its legitimate successor as evidence of the organization, functions, policies, decisions, procedures, operations or other activities of the government or because of the informational value of the data in them (NNSA/NSO, 2010).

\section{Remediation}

The process of reducing the concentration of a contaminant (or contaminants) in air, water, or soil media to a level that poses an acceptable risk to human health (ASQ, 2004).

\section{Sensitivity}

The degree to which the model outputs are affected by changes in selected input parameters (EPA, 2009).

\section{Specification}

A document that states requirements and refers to or includes drawings or other relevant documents. Specifications should indicate the means and criteria for determining conformance (ASQ, 2004).

\section{Suspect/Counterfeit Items}

An item is suspect when inspection or testing indicates it may not conform to established specifications. A counterfeit item is one that has been copied or substituted without legal right or authority or whose material, performance, or characteristics have been misrepresented by the supplied or manufacturer (DOE, 2005).

\section{Uncertainty}

Describes the lack of knowledge about models, parameters, constants, data, and beliefs. Sources of uncertainty include the science underlying a model, input data, observation error, and code uncertainty (EPA, 2009). 


\section{Definitions (Continued)}

\section{Validation}

Confirmation through provision of objective evidence that the requirements for a specific intended use or application are fulfilled. Data validation is an analyte and sample-specific process that determines the analytical quality of a specific dataset (ASQ, 2004).

\section{Verification}

Confirmation through provision of objective evidence that specified requirements have been fulfilled. Data verification is a sampling and analysis process evaluation of the completeness, correctness, conformance, and compliance of a specific dataset against the method, procedural, or contractual requirements (ASQ, 2004). 


\section{A Project Management}

This Quality Assurance Project Plan (QAPP) provides the overall quality assurance (QA) program requirements and general quality practices to be applied to the U.S. Department of Energy (DOE), National Nuclear Security Administration Nevada Site Office (NNSA/NSO) Underground Test Area (UGTA) Sub-Project (hereafter the Sub-Project) activities. The requirements in this QAPP are consistent with DOE Order 414.1C, Quality Assurance (DOE, 2005); U.S. Environmental Protection Agency (EPA) Guidance for Quality Assurance Project Plans for Modeling (EPA, 2002); and EPA Guidance on the Development, Evaluation, and Application of Environmental Models (EPA, 2009). The QAPP Revision 0 supersedes DOE--341, Underground Test Area Quality Assurance Project Plan, Nevada Test Site, Nevada, Revision 4.

The NNSA/NSO, or designee, shall review this QAPP every two years. Changes that do not affect the overall scope of the Sub-Project (i.e., change in contractor or contractor scope), or a requirement, will not require a QAPP revision but will be incorporated into the next revision cycle after identification.

Section A describes the Sub-Project objectives, participant roles and responsibilities, and administrative and management quality requirements (i.e., training, records, procurement). Section A also details data quality indicators (DQIs), data management, and computer software requirements. Section B establishes the requirements to ensure newly collected data are valid, existing data uses are appropriate, and environmental-modeling methods are reliable. Section C provides feedback loops through assessments and reports to management. Section D provides the framework for corrective actions. Section E provides references for this document.

\section{A.1 Problem Definition and Background}

Underground testing of nuclear weapons was conducted from 1951 to 1992 at the Nevada Test Site (renamed the Nevada National Security Site [NNSS] in 2010). As an unavoidable consequence of these testing activities, radionuclides were introduced into the subsurface environment and have impacted the groundwater. The Sub-Project was initiated to assess the risk to the public from the radiologically contaminated groundwater produced by nuclear testing. 
The nuclear testing locations assigned to the Sub-Project are grouped into five Corrective Action Units (CAUs): Yucca Flat/Climax Mine (CAU 97), Frenchman Flat (CAU 98), Rainier Mesa/Shoshone Mountain (CAU 99), Central Pahute Mesa (CAU 101), and Western Pahute Mesa (CAU 102). The Sub-Project has combined the CAU 101 and 102 investigations. For the Sub-Project, contaminated groundwater is defined as exceeding the radiological standards of the Safe Drinking Water Act (SDWA) (CFR, 2010a), the State of Nevada's groundwater-quality standard to protect human health and the environment. One objective of the Sub-Project is to determine a contaminant boundary. A model forecast is a three-dimensional (3-D) volume, and this volume is projected upward to the ground surface to define a two-dimensional (2-D) contaminant boundary perimeter. Simulation modeling of contaminant transport is used to forecast the location of contaminant boundaries within 1,000 years and must show the 95th percentile of the model results (i.e., boundary outside of which less than 5 percent of the simulations exceed the SDWA standards [CFR, 2010a]).

The UGTA corrective action strategy is documented in Appendix VI, Section 3.0, of the Federal Facility Agreement and Consent Order (FFACO) (1996, as amended).

\section{A.2 Sub-Project Description}

The Sub-Project provides the characterization, monitoring, and model forecasts to facilitate informed regulatory decisions. The Sub-Project purpose is accomplished through a tripartite strategy that integrates and balances (1) site characterization and modeling studies, (2) monitoring to test model forecasts and ensure compliance, and (3) institutional controls to restrict public access to contaminated groundwater. This approach is consistent with the guidance by the National Research Council on the use of models in environmental regulatory decision making (NRC, 2007). The activities are directed by the FFACO (1996, as amended). The UGTA corrective action strategy has four stages:

1. Corrective Action Investigation Plan (CAIP)

2. Corrective Action Investigation (CAI)

3. Corrective Action Decision Document (CADD)/Corrective Action Plan (CAP)

4. Closure Report (CR) 
A flowchart of the major steps for the four UGTA strategy stages is available in Appendix VI, Section 3.0, of the FFACO (1996, as amended). Successful stage completion leads to closure of CAUs and implementation of long-term closure monitoring programs.

\section{A.2.1 Schedule}

Each stage outlined in Section A.2 must be completed for each CAU. Milestones and schedules for the Sub-Project are established by NNSA/NSO and the Nevada Division of Environmental Protection (NDEP) in accordance with the FFACO. Part XII.4 of the FFACO requires annual meetings to establish priorities, milestones, and due dates for the current fiscal year. Monthly progress reports and lifecycle baselines are posted to the FFACO website; however, NDEP has limited access.

\section{A.3 Project Roles and Responsibilities}

The DOE, NNSA/NSO personnel and Sub-Project participants' responsibilities are described in the following subsections. Participants' responsibilities, scope, and names are expected to change throughout the life of the Sub-Project.

\section{A.3.1 Environmental Restoration Project}

The DOE, NNSA/NSO personnel are responsible for achieving quality within the specific projects they manage. The personnel described in the following subsections may be termed "NNSA/NSO" in the rest of the document.

\section{A.3.1.1 Federal Director}

The Federal Director is responsible for the administration of the Environmental Restoration Project and reports to the Assistant Manager for Environmental Management. The Federal Director has oversight and management responsibilities for environmental restoration projects, and is responsible for ensuring that quality requirements are established and implemented.

\section{A.3.1.2 Federal Sub-Project Director}

The Federal Sub-Project Director reports directly to and is the prime point of contact for the Federal Director. The Federal Sub-Project Director has day-to-day management responsibilities for technical, 
financial, and scheduling aspects, and shall monitor participant performance. At a minimum, the Federal Sub-Project Director is responsible for the following duties:

- Review and approve or concur with Sub-Project plans, including this QAPP.

- Establish and approve Sub-Project milestones.

- Disseminate pertinent information from NNSA/NSO.

- Implement FFACO requirements, including revisions.

- Ensure activities are appropriately planned, evaluated, and implemented to achieve Sub-Project objectives.

- Monitor Sub-Project activities to ensure compliance with requirements of this QAPP, and provide direction and guidance for improvement.

- Verify through assessments that Sub-Project participants are adequately executing their responsibilities.

- $\quad$ Provide NDEP with an annual QA report and list of participants.

- Notify and apprise the Federal Director, and other involved personnel of significant conditions adverse to quality, safety, health, or the environment.

\section{A.3.1.3 Federal Task Manager}

The Federal Task Manager reports directly to the Federal Sub-Project Director. The Federal Task Manager has day-to-day management responsibilities for technical and scheduling aspects for assigned Sub-Project tasks, and shall monitor participant performance of task activities. At a minimum, the Federal Task Manager is responsible for the following duties:

- Ensure effective communication among participants.

- Participate in activity organization and planning.

- Perform periodic independent assessments (see Section C.1.3) of activities under his or her purview.

- Provide direction and guidance for improvement.

- Notify the Federal Director, Federal Sub-Project Director, and other involved personnel of significant conditions adverse to quality, safety, health, or the environment. 


\section{A.3.2 Sub-Project Participants}

Page 5 of 65

The UGTA Program Management Plan (DOE/NV, 1999) provides guidance for the implementation and organizational structure for meeting the Sub-Project objectives. Participants are responsible for developing applicable procedures for their assigned scope of work and must ensure work is performed in accordance with applicable federal, state, and local regulations, as well as approved project plans. The plans and procedures shall be consistent with individual contracts and agency agreements. To fulfill responsibilities specific to QA, participants are, at a minimum, responsible for the following:

- Report to the Federal Sub-Project Director and Federal Task Manager regarding scope, schedules, costs, technical execution, and quality achievement of task order activities.

- Develop a quality implementation plan or matrix of procedures that demonstrates the requirements of this QAPP are met and implemented.

- Ensure that proper resources and QA activities are integrated into Sub-Project activities.

- Evaluate activities to ensure requirements are implemented.

- Implement applicable procedures and instructions.

- Ensure personnel are trained and qualified to achieve initial proficiency; maintain proficiency; and adapt to changes in technology, methods, and job responsibilities.

- Perform management self-assessments (see Section C.1.2) to verify compliance with applicable requirements.

- Identify deficient areas, implement effective corrective actions, and verify actions are effective.

- Notify the Federal Sub-Project Director, Federal Task Manager, and other involved personnel about significant conditions adverse to quality, safety, health, the environment, or any adverse trends.

\section{A.3.2.1 Desert Research Institute}

Desert Research Institute (DRI) performs multiple activities in the laboratory and field, as well as various data analysis and modeling tasks. Their major services include, but are not limited to, groundwater flow and transport modeling; water-rock geochemical reaction modeling; isotope 
hydrology; laboratory analytical support (i.e., aluminum, iron, dissolved organic carbon, and isotopic analyses); laboratory studies of hydrological and transport properties; groundwater recharge estimation; specialty borehole logging (i.e., water quality and flow logging); cultural resource surveys; and historical impact studies performed before ground-disturbing activities can occur. The DRI is also involved in technology development activities such as optimized well-siting research and development of in situ sensors.

\section{A.3.2.2 Environmental Restoration Contractor}

The Environmental Restoration (ER) contractor provides environmental assessment, groundwater characterization, and remediation services. The ER contractor provides Sub-Project integration, planning, and management support, including preparation of FFACO documents; Sub-Project technical documents (e.g., hydrologic and transport data documents, flow and transport model reports, flow and transport model peer review reports, technical strategy plans); QA plans; and safety plans. Other services include, but are not limited to, groundwater flow and transport modeling; geochemical evaluations; collecting, managing, and analyzing technical and nontechnical Sub-Project data; well development and testing; support to drilling; sampling of characterization, model-evaluation, and monitoring wells; analytical services; and waste management.

\section{A.3.2.3 Management and Operating Contractor}

The management and operating $(\mathrm{M} \& \mathrm{O})$ contractor provides drilling and construction management and oversight, as well as geologic expertise. Their services include, but are not limited to, architectural, engineering, and inspection services; logistical and technical support for drilling, completing, and testing of characterization, model-evaluation, and monitoring wells; and site development activities, including roads and utilities. Other support includes geologic technical support (such as geologic characterization of drill holes and preparation of well completion reports); field geodetic surveys; materials-testing and laboratory services for design and construction activities; Sub-Project management control and reporting support; endangered species (ecological) surveys; and radiological monitoring and control. The M\&O contractor is also responsible for developing the hydrostratigraphic framework models (HFMs), related geologic studies, and the HFM document for each CAU. 


\section{A.3.2.4 National Laboratories}

Lawrence Livermore National Laboratory (LLNL) and Los Alamos National Laboratory (LANL) perform multiple activities in the laboratory and field, as well as various data analysis and modeling tasks. The services provided by LLNL and LANL include, but are not limited to, groundwater flow and transport modeling; laboratory studies of hydrological and transport properties; surface and borehole geophysics; geochemical evaluations; source term analysis and modeling; and laboratory analytical support (i.e., trace element, inorganic, isotopic ratio, and hot-well analyses).

\section{A.3.2.5 U.S. Geological Survey}

The U.S. Geological Survey (USGS) provides, but is not limited to, technical support for water-level measurements, aquifer characterization, and surface geophysics; geologic sample storage and maintenance; laboratory analytical support (i.e., trace element and isotopic analyses); geochemical evaluations; regional and local geologic and hydrologic interpretations of groundwater characterization activities; and regional groundwater flow modeling studies.

\section{A.3.3 Subcontractors}

Subcontractors are subject to the same requirements as Sub-Project participants. Verification of subcontractor conformance is the responsibility of the organization procuring the subcontract. Participants shall ensure the flow down of applicable requirements to their subcontractors.

\section{A.3.4 Interfaces}

Contract Managers, CAU Leads, and the Science Advisor maintain frequent communication, and are the primary interfaces with NNSA/NSO personnel. Specific responsibilities for the primary interfaces are described within this section.

\section{A.3.4.1 Contract Managers}

Each Sub-Project participant assigns a Contract Manager responsible for managing the Sub-Project participant's tasks. This includes developing scope, schedule, and budgets; managing resources; documenting and communicating progress; developing, authorizing, and complying with program plans such as health, safety, and QA plans; planning lifecycle tasks; and coordinating with the other 
participants to conduct technical tasks. Contract Managers shall meet on a regular basis with NNSA/NSO personnel.

\section{A.3.4.2 CAU Leads}

The CAU Lead is responsible for identifying and coordinating CAU-specific technical scope and priorities; coordinating with other CAU Leads to maintain consistency between CAUs; coordinating technical reviews; evaluating and prioritizing data needs; providing technical oversight to the CAU team; focusing Pre-Emptive Review Committee reviews; and communicating progress. The CAU Leads shall meet on a regular basis with NNSA/NSO personnel.

\section{A.3.4.3 Science Advisor}

The Science Advisor acts as an independent advisor for technical topics, project strategy, and conceptual-model development; application of flow and transport models; uncertainty and sensitivity analyses; compliance with environmental standards; and data collection. The Science Advisor also provides technical communications for NNSA/NSO and regulatory agencies, including development and/or review of white papers, presentations, technical plans, and reports as requested. The Science Advisor participates in all Pre-Emptive Review and Technical Working Group (TWG) Committees.

\section{A.3.5 Committees}

The following sections describe the standing and ad hoc committees used by the Sub-Project.

\section{A.3.5.1 Technical Working Group}

The TWG is an as-needed review team composed of representatives from ER and M\&O contractors, DRI, USGS, LLNL, and LANL. The NDEP and NNSA/NSO representatives are ex-officio participants. The TWG recommendations are limited to technical scope within the constraints of Sub-Project plans endorsed by the Federal Sub-Project Director.

\section{A.3.5.2 Pre-Emptive Review Committees}

The CAU-specific Pre-Emptive Review Committees provide internal technical review of ongoing work throughout the CAU lifecycle. The reviews assure the work is comprehensive, accurate, in 
keeping with the state of the art, and consistent with CAU and Sub-Project goals. Pre-Emptive Review Committee members are Sub-Project participants with the appropriate expertise but are not directly responsible for CAU products. The committee membership shall consist of a core team, consistent throughout the CAU lifecycle, and additional subject matter experts as needed. As part of their oversight, NDEP may have ex-officio member(s) on the committee.

The Science Advisor, with the Contract Manager's consent, appoints a Chairperson, assigns subject matter experts, and notifies the Federal Sub-Project Director of the committee membership. The Chairperson, or designee, facilitates, participates in, and documents committee activities, including membership, agendas, presentations, decisions, and recommendations. The CAU Lead shall establish technical priorities, work focus, and review criteria. The CAU Lead, Chairperson, and Science Advisor identify action items, track progress to resolution, and communicate with NNSA/NSO personnel.

\section{A.3.5.3 Topical Committees}

Topical Committees (formerly standing subcommittees of the TWG) may be formed on an ad hoc basis to address items such as non-CAU-specific issues, questions, concerns, and readiness. Any participant may identify the need for the committee to the Contract Manager and the Science Advisor. The Science Advisor, with the Contract Manager's consent, shall set goals and expectations; appoint a chairperson; assign the suitable subject matter experts (may include experts external to the Sub-Project); and notify the Federal Sub-Project Director of the committee and issue. The Chairperson, or designee, facilitates, participates in, and documents committee activities, including membership, agendas, presentations, decisions, and recommendations. These committees are disbanded when the work is complete.

\section{A.3.5.4 Drilling Advisory Teams}

Drilling advisory teams make real-time decisions to facilitate meeting well objectives and completing wells. The team ensures the scientific goals of each well are met. Membership is drawn from Sub-Project participants with an emphasis on field experience. The teams are formed with the Federal Sub-Project Director's concurrence, and additional experts are added as needed. These teams are active only during drilling operations. If any decisions have CAU-wide or Sub-Project 
ramifications (e.g., number or priority of wells), the advisory team shall defer to the CAU-Specific Pre-Emptive Review Committee or a Topical Committee, respectively.

\section{A.4 Qualifications and Training}

The NNSA/NSO and Sub-Project participants' management shall ensure that personnel are qualified and knowledgeable in the activities they perform. Training should emphasize correct performance of assigned work and provide an understanding of why quality requirements exist. Personnel qualification and training documents shall be maintained as records in accordance with Section A.7.

\section{A.4.1 Sub-Project Participants}

Sub-Project participants shall be trained and qualified to perform the tasks to which they are assigned. Objective evidence of qualifications may include academic credentials, individual resumes, registrations, licenses, and training records. Participants' management shall evaluate personnel qualifications against assigned responsibilities and address any identified training needs. Participants, either individually or cooperatively, shall provide training to achieve and maintain proficiency; adapt to changes in technology, methods, or job description; and allow for feedback and effectiveness of job performance. Training may take the form of orientation, indoctrination, formal classroom, or on-the-job training. This training shall include regulatory requirements, scopes of work, QA/quality control (QC) requirements, and applicable work instructions.

On-the-job training shall be conducted and documented by personnel experienced in the task being performed in accordance with each organization's requirements. Any work performed by a trainee should be under the supervision of an experienced individual. Trainees should demonstrate capability before performing work independently.

\section{A.4.2 Subcontracts}

Subcontractor personnel shall be qualified and trained to perform the duties for which they were contracted. The contracting organization shall be responsible for verifying the qualifications of subcontracted personnel. 


\section{A.5 Quality Objectives and Criteria}

Contract Managers shall apply requirements using a graded approach. The graded approach is based on the level of managerial controls applied to an item, data, or activity according to the intended use and degree of confidence needed in the quality of the results. The performance criteria establish the QA needed for data and models.

The Sub-Project has incorporated an iterative process similar to EPA's Data Quality Objective (DQO) process (EPA, 2006) to establish the quality requirements. Because both data collection and modeling are performed, different quality systems are used. Data quality uses data indicators, identified before sampling, to establish the confidence needed. Modeling quality objectives are associated not only with data uncertainty but also with providing a probabilistic representation of the complex environmental system. The QA requirements associated with sampling parameter distributions, multiple realizations of the models, and model evaluations establish the confidence needed in the model results. The following section describes the quality objective process for the Sub-Project.

\section{A.5.1 Quality Objective Process}

The EPA DQO process (EPA, 2006) is a systematic project planning tool to help define the environmental problem, identify the information needed to address the problem, and design an investigation program to gather the necessary data. This is an iterative process with the goal to ensure the Sub-Project produces the right type, quality, and quantity of data to achieve the intended outcome. The Sub-Project follows the process as a whole, incorporating the FFACO (1996, as amended) and model requirements as described below. The seven steps of the DQO process are as follows:

1. State the problem.

2. Identify the goal of the study.

3. Identify information inputs.

4. Define the boundaries of the study.

5. Develop the analytic approach.

6. Specify performance or acceptance criteria.

7. Develop the plan for obtaining data. 
For the Sub-Project, the problem (Step 1) is stated in the FFACO (1996, as amended) and in Section A.1: Groundwater on the NNSS has been contaminated with radionuclides as a result of underground nuclear testing. The primary Sub-Project objective is to define contaminant boundaries for each CAU-enclosing area that may potentially exceed the radiological standards of the SDWA (CFR, 2010a) over the next 1,000 years. The goal (Step 2) is to provide the data, model forecasts, and confidence in the model results to facilitate informed regulatory decisions by NDEP and NNSA/NSO. The UGTA strategy recognizes the need for understanding uncertainty in modeling studies and uses EPA guidelines (EPA, 2009) to define model development (CAI stage), model evaluation (CADD/CAP stage), and model application (CR stage). There are inherent limitations associated with models of complex hydrogeological settings. Modelers evaluate them through a combination of quantification of uncertainty and multiple alternative interpretations of model components (see Section B.5.5).

The UGTA strategy identifies the information needed for creating models of contaminant boundaries (Step 3) during the CAIP stage. The value of information analysis is prepared during the CAIP stage and includes the following:

- Compilation of existing data from the regional data documentation packages

- Identification of data needs and gaps

- Identification of sensitive parameters

- Identification of quantity and quality of additional data needs, and characterization options

- Cost of characterization options

- Effect of data characterization options on uncertainty reduction

- Comparison of characterization options through decision analysis

The DQOs for the data needs are documented in the CAIP. The CAIP must be approved by NDEP before the CAI stage begins.

Model boundaries are defined (Step 4) during the CAI stage and documented in the flow and transport model documents. Contaminant boundaries are documented in the transport model document.

The analytic approach, or decision rule (Step 5), is outlined in the CAIP and includes developing groundwater flow and transport models that are composed of a group of model components, including an HFM, flow model, source term model, and transport simulations (see Section B.5.1) that are 
documented in the flow and transport modeling reports. A separate modeling strategy document may be developed.

The FFACO (1996, as amended) requires the models to have the ability to forecast the location of contaminant boundaries within 1,000 years and show the 95th percentile of the model results (performance criteria, Step 6). Therefore, data collection must be adequate to develop and evaluate models with that level of performance. Criteria for field and laboratory measurements and modeling activities are described in Section B and Attachments 1 and 2.

In addition to the overall criteria, the FFACO also requires CAU models to consider the following, at a minimum:

- Alternative HFMs of the CAU modeling domain

- Uncertainty in the radiological and hydrological source term

- Alternative models of recharge

- Alternative boundary conditions and groundwater flows

- Multiple permissive sets of calibrated flow models

- Probabilistic simulations of transport using plausible sets of alternative framework and recharge models, and boundary and groundwater flows from calibrated flow models

- Ensembles of forecasts of contaminant boundaries for the CAU

- Sensitivity and uncertainty analyses of the model outputs

A plan for obtaining data (Step 7) is developed during the CAIP stage and refined in the CAI stage. New data are collected during the CAI stage to address deficiencies in existing data, or to improve the assimilation and utilization of existing data.

The DQO process is repeated for any additional data collection activities needed to increase confidence in model results (CADD/CAP stage) or long-term monitoring (CR stage). If new information requires changes in the $\mathrm{CADD} / \mathrm{CAP}$ or $\mathrm{CR}$, a summary report or addendum will be developed and submitted for review and approval by NDEP. 
The UGTA strategy also has several built-in decision points used to determine whether the objectives have been met for the given stage. These decision points provide opportunities for NDEP and NNSA/NSO to assess the work products and decide whether results are sufficient to proceed to the next step. If work products are not acceptable, remedial actions may include collecting additional data, refining the model or monitoring network, or revising the strategy.

\section{A.5.2 Data Quality Indicators}

The DQIs measure features of data quality such as precision, bias, accuracy, representativeness, completeness, and comparability. Sampling and analytical data goals are based on the intended use of the data, field procedures, instrumentation, and available resources. Sub-Project participants shall establish and document the DQI goals during their planning process. The planning documents or activity procedures shall provide the information necessary to achieve the goals established. After data collection, each participant shall perform and document an evaluation of the data against the DQIs to determine whether the quality goals have been accomplished. Participants shall consider the DQIs described in the following subsections when planning, performing, and evaluating Sub-Project activities. Every DQI may not apply to all data collection activities.

\section{A.5.2.1 Precision}

Precision measures the reproducibility of data under a given set of conditions. Specifically, precision is a quantitative measurement of the variability of a population of measurements compared to their average value. Where applicable, precision shall be assessed by evaluating replicate measurements. Precision will be reported using a standard descriptive statistic such as the relative percent difference (RPD), standard deviation, confidence level, or coefficient of variation. If predetermined limits for a given parameter are exceeded, the data shall be evaluated for usability based on the data purpose and reasons for the reduction in precision.

\section{A.5.2.2 Bias}

Bias describes any systematic deviation between a measured (i.e., observed) or computed value and its "true" value. Bias is affected by faulty instrument calibration and other measurement errors, systematic errors during data collection, and sampling errors such as incomplete spatial randomization during the design of sampling programs. Bias evaluations should address whether 
(1) the bias in analytical results is documented; (2) the dataset characteristics directly impact the output; (3) information is sufficient to identify, estimate, document, and correct the bias; and (4) adequate data are available in the upper and lower extremes of the tails to allow for unbiased probabilistic estimates if the data are used to develop probability distributions (EPA, 2002).

\section{A.5.2.3 Accuracy}

Accuracy is defined as the nearness of a measurement to the true or accepted reference value. It is the composite of the random and systematic components of the measurement, and measures error in a measurement process (if the true value is known). Values exceeding the acceptance criteria for accuracy, established during the planning process, must be evaluated for corrective actions.

\section{A.5.2.4 Representativeness}

Representativeness measures the degree to which sample data accurately and precisely represent a characteristic of a sample population, a parameter variation at a sampling point, a process condition, or an environmental condition. Representativeness of a sample depends on the proper design and execution of a sampling program. It is achieved through careful selection of sampling intervals and locations, as well as analytical parameters and collection methods. The DQIs for representativeness should address whether the (1) data were collected from a population sufficiently similar to the population of interest (see Section A.8.3); (2) sampling and analytical methods used to generate the collected data were acceptable; and (3) potentially confounding effects in the data (e.g., season, time of day, location, and scale incompatibilities) were addressed so that they do not unduly impact the model output (EPA, 2002).

\section{A.5.2.5 Completeness}

Completeness is a measure of the amount of valid data obtained from a measurement system compared to the amount that was expected to be obtained under correct, normal conditions. Completeness is affected by unexpected conditions that may occur during the data collection process. The number of samples prescribed for an activity must be sufficient to meet data requirements identified in the planning process and must consider typical loss of data caused by handling, shipping, and analytical processes. 


\section{A.5.2.6 Comparability}

Comparability describes the extent to which data from one study can be compared directly to either past data from the current project or data from another study. It is a qualitative term that expresses the confidence that the multiple datasets can contribute to a common analysis, and it is achieved by using standard techniques and procedures to collect and analyze representative samples.

\section{A.6 Document Control}

Documents are developed to ensure that work is effectively managed, performed, and assessed to ensure quality. Documents that prescribe technical processes, specify quality requirements, or establish management controls shall be developed, reviewed, and approved in accordance with the participant's procedures. Sub-Project documents (i.e., FFACO mandated) shall be controlled by the issuing participant's system. Documents should adhere to the participant's corporate style and usage rules; or default to the U.S. Government Printing Office (GPO) Style Manual, the Chicago Manual of Style, or Merriam-Webster dictionary.

Each participant organization shall implement a system for distributing controlled documents to ensure personnel are supplied with the necessary documents so work is performed as prescribed by the most current version of the document. The system shall also control those Sub-Project documents assigned to the individual participant. The process shall incorporate controls for identifying controlled copy holders, establishing effective dates, and assigning a unique identifier for each controlled copy. If electronic systems are employed, users must be notified that printed copies are uncontrolled. Documents no longer in use should have their status clearly indicated, and record copies shall be maintained in accordance with the applicable records inventory and disposition schedule.

\section{A.6.1 Revisions}

Revisions to approved procedures, plans, or documents may be necessary. The participants shall ensure that changes are properly identified, documented, approved, and controlled in accordance with the participant procedure. Verbal authorization of changes must be documented and followed up with a written change notice in a timely manner. Revised document review may be limited to the scope of the revision; however, approval must remain at the same level of authority as the original document. 
The Federal Sub-Project Director shall be notified of changes that impact the cost or schedule of the Sub-Project.

\section{A.6.2 Protection of Documents}

Documents, plans, procedures, presentations, and data shall be reviewed in accordance with DOE Order 475.2, Identifying Classified Information (DOE, 2007a); and Manual 475.1-1B, Manual for Identifying Classified Information (DOE, 2007b).

\section{A.7 Records Management}

Participants shall maintain, or submit their records to, a record storage and retrieval system that is consistent with environmental regulations and DOE Orders 243.1, Records Management Program (DOE, 2006); 200.1A, Information Technology Management (DOE, 2008); and/or 241.1B, Scientific and Technical Information Management (DOE, 2010). This includes a storage system for computer-based information (e.g., software, models, data, and model output) that is retrievable and protected from loss, compromise, or catastrophic events. Sufficient detail shall be included in records to allow for the reconstruction of activities as well as provide traceability. Participants' plans, procedures, and program documents shall identify the resultant records. Participants shall identify appropriate storage and retention time frames.

A lifecycle approach shall be maintained for hard-copy and electronic records that ensures protection and access to records until their disposition. Records shall be destroyed according to the provisions of authorized disposition schedules.

Participants should consider the following when identifying a document, including electronic information, as a record:

- Is the document a specific and original source?

- Does the document support a regulatory decision?

- Is the document valuable for assessments?

- Does the document support other documents?

- Is the document a deliverable?

- Does the document describe work performed (e.g., completed forms, field logbooks)?

- Does the document support functions such as training, procurement, or accounting?

- Does the document require action? 
- Does the document reflect a decision, action, or lack of action?

- Is the document necessary to understand a decision, action, or non-action?

- Does the document provide context of a decisional document?

The following controls shall be applied to records. This is not intended to be an exhaustive list, and additional controls may be applied:

- Do not use whiteout, correction tape, or black permanent markers to correct errors.

- If an error is made on a record, draw a single line through the error, note the correction, then sign and date the page.

- Take necessary actions to ensure records are not damaged or susceptible to loss, liquid/food spillage, or weather elements.

- Maintain records at job sites in a manner that facilitates ease of retrieval.

- Use blue or black indelible ink to enter information into handwritten logs, logbooks, and forms.

- Number each page of logbooks sequentially.

- When handwriting information, draw a diagonal line through a page or portion of a page if it is intentionally left blank, then sign and date the page.

- Back up electronic records on a regular cycle, and store backup media in a separate location or in a two-hour fire-rated safe to safeguard against the loss of information due to equipment malfunctions or human error.

- Do not use floppy disks for the exclusive long-term storage of permanent or unscheduled electronic records, due to the instability of the medium.

Participants shall ensure that records are legible and complete. Incomplete information within a record reduces its overall value. For example, meeting minutes without a date or list of attendees have little value when establishing events. 


\section{A.8 Data Management}

Page 19 of 65

Participants shall ensure that processes are in place for the management, control, and transfer of data. The processes shall include provisions for gathering, manipulating, and distributing data, and shall address the following:

- Participants shall verify that transcription and transfer of data are performed correctly by (1) reviewing a representative sample of sufficient data points to provide confidence that data have been transcribed or transferred properly; (2) documenting the method of verification and verification results; and (3) documenting the transfer of data to software applications, including software application name and version number.

- Data used in reports, analyses, models, or interpretive works are traceable to their source.

- Data that have been manipulated are checked to ensure the manipulation process was performed as intended.

- Data are maintained during the lifetime of the project using backup and archival processes.

- Data used in reports, analyses, models, or interpretive works are maintained as records in accordance with Section A.7.

- Access to databases, datasets, and files is controlled so that unauthorized modifications or deletions are not allowed.

- Data source(s), extraction criteria, and data quality are documented or referenced, and maintained with the dataset extracted from a database.

- Data not acquired in compliance with this QAPP are evaluated for acceptability (see Section A.8.1) before use. Acceptance will be established before entry into a database, when possible. If data are incorporated into a database before documenting acceptance, the data shall be flagged and clearly identified as "preliminary."

- Data are evaluated for quality as described in Section A.8.2.

- Data collected from a location outside of the model area shall be evaluated for transferability before use (see Section A.8.3).

\section{A.8.1 Data Source Acceptance}

Data not acquired in compliance to this QAPP (e.g., non-direct data) shall be evaluated for acceptance before use by the Sub-Project. Data obtained from a peer-reviewed journal shall be considered acceptable and shall not require a source acceptance evaluation. This section presents the approach, documentation, and review for this evaluation. 


\section{A.8.1.1 Approach}

A subject matter expert or Topical Committee shall evaluate non-direct data sources (e.g., defense projects, Yucca Mountain Project, databases) to determine the appropriateness of the methods and the correctness of the resulting dataset or data source. The expert or committee shall address one or more of the following as applicable:

- The equipment and procedures used to collect and analyze the data are technically adequate (e.g., typical of scientific and industry standards).

- The extent to which the data demonstrate the properties of interest (e.g., physical, chemical, geologic, and mechanical) is reasonable given the range of inherent variability for the property.

- Conditions under which the data were obtained, if germane to the data quality, are acceptable.

- Measurements were performed in accordance with sound technical or administrative practices or procedures.

- Data have been used in similar applications.

- Data and their results have undergone prior peer or other professional review.

- A sufficient quantity of corroborating data is available to demonstrate comparability.

\section{A.8.1.2 Documentation}

The expert or committee shall develop a data acceptance report and address the following, as applicable:

- Description of data, its source, rationale for its selection, and its intended uses

- Extent and reliability of the documentation associated with the data

- Discussion of attributes described above (Section A.8.1.1)

- Prior uses of the data and associated verification processes

- Dataset(s) used for corroboration, rationale for selection, and justification of inferences drawn

- Data acquisition, collection, or development records

- DQIs (i.e., accuracy, precision, representativeness, completeness, and comparability)

- Impact of use or nonuse of data

- Uncertainties and restrictions, if any

- Assumptions, constraints, bounds, or limits on the data or source

- Data flags to be assigned to the data 


\section{A.8.1.3 Documentation Review}

If the acceptance evaluation was not performed by a committee, an independent reviewer shall review the document for the following items:

- The content of the report is technically adequate, complete, and correct.

- Uncertainties and restrictions are discussed.

- The assumptions, constraints, bounds, or limits on the data are identified.

\section{A.8.2 Data Quality Evaluation}

Participants shall ensure that data are evaluated with respect to quality before use in reports, analyses, interpretive works, or models. Data quality flags shall be assigned and documented for each individual data record or group of similar records to indicate the quality or suitability for the intended usage. Reports, models, or interpretive works shall indicate the quality of the data being used.

\section{A.8.3 Data Transferability}

The Sub-Project relies on data transferability as a process to determine whether data from other locations (e.g., geophysical, chemical) can be used to support groundwater flow, radionuclide transport, and other models within a CAU (i.e., the properties are transferred to the CAU). Participants shall determine the transferability of data using the following steps (SNJV, 2004):

1. Establish acceptance criteria based on the use of the parameter and its importance. These criteria are established before the modeling simulations and the uncertainty and parameter sensitivity evaluations are performed. Changes in the criteria might be expected as the CAU investigations and modeling progress. Thus, if it is determined that more restrictive criteria are needed for a particular parameter, it will be necessary to repeat the transferability evaluation. If the previously used criteria are restrictive enough, it will not be necessary to re-perform the evaluation.

2. Evaluate whether geologic, geochemical, hydrologic, or other factors would disqualify the measurement for use by the Sub-Project.

3. Document the process and data used in sufficient detail that others can understand and repeat the process. This information should be incorporated either directly or by reference. 
The approach for implementing the data transfer process shall be parameter specific and shall consider the following, if applicable:

- Parameter characteristics, including underlying dependencies on other parameters

- Similarity of geologic setting and other relevant characteristics

- Type of measurement and/or interpretative technique, including measurement scale

- Modeling approach, including conceptual models and model scale

- Heterogeneity

- Range in values

- Sensitivity of contaminant boundary to parameter value

Reports, models, or interpretive works shall describe the transferability of the data being used.

\section{A.9 Computer Software and Codes}

Participants shall develop and implement procedures for the development (if necessary), modification, verification, and control of computer software codes. The Sub-Project uses three types of computer code: (1) commercially available off the shelf; (2) acquired from other participants or other non-commercial sources, including open source; and (3) internally developed. Acquisition of commercially available off-the-shelf software shall be controlled through the procurement process. Commercial software should be evaluated for proper installation. Table A-1 presents the requirements for each code type.

Table A-1

Code Requirements

\begin{tabular}{||c|c|c|c|c|c|c|}
\hline Type & $\begin{array}{c}\text { Selection } \\
\text { (Section A.9.1) }\end{array}$ & $\begin{array}{c}\text { Development } \\
\text { (Section A.9.2) }\end{array}$ & $\begin{array}{c}\text { Verification } \\
\text { (Section A.9.3) }\end{array}$ & $\begin{array}{c}\text { Installation } \\
\text { Testing } \\
\text { (Section A.9.4) }\end{array}$ & $\begin{array}{c}\text { Code Review } \\
\text { (Section A.9.5) }\end{array}$ & $\begin{array}{c}\text { Configuration } \\
\text { Control } \\
\text { (Section A.9.6) }\end{array}$ \\
\hline \hline Commercial & $\mathrm{X}$ & -- & -- & -- & -- & $X$ \\
\hline Acquired & $\mathrm{X}$ & -- & -- & $X$ & $X$ & $X$ \\
\hline $\begin{array}{c}\text { Developed } \\
\text { Revised or } \\
\text { Modified }\end{array}$ & $\mathrm{X}$ & $\mathrm{X}$ & $\mathrm{X}$ & $\mathrm{X}$ & $\mathrm{X}$ & $\mathrm{X}$ \\
\hline
\end{tabular}

-- = Not applicable 


\section{A.9.1 Selection}

Page 23 of 65

Participants shall identify the required and desirable attributes of a code before procurement, acquisition, or development. These attributes may be identified in procurement, installation, or technical review documents. Participants shall evaluate codes based on the identified attributes, and those without the required attributes shall be eliminated from consideration. A test problem may be created to evaluate candidate codes. The tests or documentation should compare simulation results with published analytical solutions and/or other code results. If no available code performs to the required attributes, the participant may develop the needed code.

Participants shall document the code selected for the groundwater flow and transport model and the selection criteria in the CAIP. If a code change is required after publication of the CAIP, justification for the change and the potential codes shall be submitted to the Federal Sub-Project Director for approval. The justification shall incorporate, at the minimum, a justification for the change, code attributes, testing results against the above criteria, and a comparison between available codes. Upon approval, either a CAIP addendum or record of technical change shall be submitted to NDEP for approval. Participants shall document other code selection within a record package.

\section{A.9.2 Development}

Participants developing code or software shall ensure that the purpose and requirements of the code are clearly and precisely documented before development. Developed software shall be uniquely identified, and documentation shall include the following, at a minimum:

- Input and output requirements (including the range of acceptable inputs)

- Functional requirements including the operating system(s)

- Assumptions

- Identification of any limitations on applications

- Identification of the compiler and its version

- Instructions adequate for installation and execution of the software

- Description and equations, algorithms, and numerical solution techniques, as applicable

The developer shall develop a test case for software intended for multiple users. The test case shall be provided for installation testing (see Section A.9.4) to ensure that the software is functioning as intended and that results are consistent with those observed by the code developer. The test case shall be provided to the users and shall include acceptance criteria for the results. Test case documentation 
shall include any necessary instructions and input data to execute (clearly identifying the specific application[s] tested).

\section{A.9.3 Verification}

Once code development is complete, the code developer, or designee, shall verify and document that the code performs the intended functions correctly and that the documentation identified in Section A.9.2 is complete. The verification required shall depend on the complexity, risk, and uniqueness of the code. Code modifications shall be verified according to the same requirements as the original code. Verification of changes may be limited to the scope of the modification if the rest of the code is not affected. Verifiers may use ASTM International (ASTM) D6025, Section 7.6: “Code Testing Evaluation Criteria" (ASTM, 1996), for determining appropriate measures for the evaluation. Verification documentation shall describe the testing and results.

\section{A.9.4 Installation Testing}

Upon installation of software or code on a computer, operational checks (i.e., test cases provided by code developer) shall be performed to verify that the software is functioning as intended. Installation testing results must agree within the test-specified acceptance criteria before code application proceeds. Installation testing shall be conducted when operation and hardware system configurations change.

\section{A.9.5 Code Review}

Code reviews shall be performed and documented to ensure that codes, and code applications, are technically adequate and properly documented, and satisfy established technical and quality requirements. This review documents that the code was accepted by the participant before it was placed in configuration control. The review may be conducted by a subject matter expert, Topical Committee, or Pre-Emptive Review Committee, depending upon the code use. Reviewers shall possess the appropriate technical expertise and shall not have participated in the development or installation testing of the code. The reviewer(s) shall address the following elements, as applicable:

- Is the code appropriate for its intended application?

- Are the assumptions reasonable and valid? 
- Are the mathematical model and mathematical operations correct?

- Do the methods conform to accepted and published concepts?

- Are results consistent with known data using either visual or quantitative measures?

- Is documentation sufficient to reproduce development or testing, as applicable?

- Is verification adequate to ensure confidence in the software/code?

\section{A.9.6 Configuration Control}

Participants shall maintain an inventory of computer software and codes used and develop and implement a system for identifying, revising, and controlling hardware/software configurations in accordance with DOE Order 200.1A, Information Technology Management (DOE, 2008). The configuration of software shall be controlled and documented so traceability is maintained until software retirement. Codes shall undergo maintenance, verification, and instruction manual updates by the participant responsible for the code development and/or configuration control. Participants shall obtain documentation for commercially available or acquired software. This documentation should contain reference material, operational test records, and user-oriented information, as available, and shall be maintained as records.

Configuration items include, but are not limited to, the following:

- Operating system components

- Runtime libraries, if applicable

- Software executables

- Source code files, if available

- Users documentation, including software requirements and designs

- Test plans and procedures

- Software development and quality planning documents

- Documentation of technical reviews

\section{A.10 Procurement}

Participants must have procurement processes in place that meet the requirements of their contracts, agreements, or applicable federal requirements. Participants shall establish controls to ensure that, at a minimum, procured items and services meet specifications delineated in the procurement documents. Each participant shall have systems to track items and confirm delivery of procured items and services. 
The procuring organization must verify the capabilities and qualifications of subcontractor personnel to determine the type and amount of training and supervision needed. Contracts shall require commercial laboratories to participate in a performance evaluation program and the U.S. Department of Energy Consolidated Audit Program (DOECAP) or equivalent.

\section{A.10.1 Procurement Documents}

Procurement documents shall define the scope of work for the item or service being procured; and provide specifications, acceptance criteria, shipping and handling requirements, health and safety requirements, environmental compliance requirements, and documentation, as required. Technical specifications shall either be directly included in the procurement documents or included by reference to specific drawings, specifications, procedures, regulations, or codes that describe the items or services to be furnished. Procurement personnel shall review documents for accuracy and completeness before initial issue. Changes to a procurement document require the same level of review and approval as the original document.

\section{A.10.2 Instrument/Equipment Testing, and Inspection}

Receipt inspections and acceptance testing shall be accomplished by trained personnel, in accordance with approved inspection documents and test procedures that reflect acceptance and performance criteria. Inspections and testing results shall be maintained as records. Quality-affecting materials used during characterization, corrective action, or sampling activities shall be inspected upon receipt for adequacy. Any item or work product determined to be defective shall be segregated and/or controlled to avoid inadvertent use.

\section{A.11 Identification and Control of Items}

Participants shall establish and document sufficient controls to ensure that quality-affecting items such as equipment, components, and material can be readily identified. These controls shall be established to prevent incorrect use, retain integrity of materials, and preserve the desired operating characteristics of equipment and standards. 


\section{A.11.1 Suspect and Counterfeit Items}

Participants shall establish effective controls for the prevention, detection, and disposition of suspect and counterfeit items (such as bolts and lifting straps) when such items could lead to unexpected equipment failures or to negative impacts to mission, the environment, or personnel.

\section{A.12 Measuring and Test Equipment}

Participants shall uniquely identify and control their measuring and test equipment (M\&TE), and establish a system of calibration and preventive maintenance to ensure proper operation. Reference standards of the correct type, range, and acceptable uncertainty shall be used for collecting data consistent with the project objectives.

\section{A.12.1 Equipment Calibration}

Participants shall calibrate M\&TE in accordance with their procedures. The frequency of periodic or factory calibrations shall be based on the manufacturer's recommendations, national standards of practice, equipment type and characteristics, and past experience. The M\&TE or field personnel shall perform operational and/or source-response checks before work begins, and at frequent intervals to verify continued accuracy and function.

The M\&TE or field personnel shall tag equipment for which the periodic calibration period has expired, equipment that fails calibration, or equipment that becomes inoperable as "out of service." When possible, this equipment shall be segregated to prevent inadvertent use. Results of activities performed using equipment that is out of calibration shall be evaluated for adverse affects and the appropriate personnel notified.

Physical and chemical standards shall have certifications traceable to EPA, the National Institute of Standards and Technology (NIST), or other nationally recognized agencies, if available. Supporting documentation on reference standards and equipment shall be maintained as records.

\section{A.12.2 Preventive Maintenance}

Participants shall perform periodic preventive maintenance on field and laboratory equipment. The frequency of preventative maintenance should be based on manufacturer's recommendations and the 
user's professional knowledge and experience. Participants shall document their preventative maintenance schedule(s) (e.g., in instrumentation procedures or laboratory maintenance plans) and maintain maintenance records. 
The Sub-Project requires a significant number of data collection tasks - including field activities, laboratory analyses, and laboratory studies - to support the development of groundwater flow and transport models. This section presents the work processes used to ensure the data and associated documentation are sufficient to support the development of defensible groundwater flow and transport models. This section also presents modeling development, verification, calibration, and uncertainty and sensitivity analyses.

\section{B.1 Field Activities}

Attachment 1 identifies common field data collection activities and the responsible participant or subcontractor. Modifications from the parameters and procedures listed in Attachment 1 are evaluated on a case-by-case basis by the responsible participant. Participants shall ensure the quality and integrity of field data collection through approved field activity work packages (FAWPs), standard operating procedures (SOPs), instructions, plans, qualified personnel, appropriate tools, and calibrated equipment.

\section{B.1.1 Planning Documentation}

Participants shall perform fieldwork safely and within the controls established by Real Estate/Operations Permits (REOPs) and FAWPs. Details for data collection activities shall be documented in the associated project plans, task plans, activity plans, field instructions, and/or SOPs (see Attachment 1). Participant activity-specific plans or instructions shall detail unique or experimental methods, or methods under development. Field activities are controlled, at a minimum, by the following documents, as applicable:

Drilling and Completion Criteria Document - The criteria document describes the drilling and completion specifications for CAU-specific wells. The document includes a discussion of the scientific objectives of the program, well locations and settings, general well drilling and completion information, data collection procedures, and relevant operating procedures. 
Real Estate/Operations Permit - The REOP process ensures that work performed under the NNSA/NSO's purview is well defined, properly authorized, and effectively managed. The permit identifies geographical location boundaries and hazards, and establishes and implements controls to mitigate those hazards.

Standard Operating Procedures - Participants' SOPs are developed to implement specific technical and quality objectives. The SOPs shall be based on well-established methods (e.g., ASTM, EPA, or Soil Science Society of America) when possible; shall identify the DQIs and associated acceptance criteria for the measurements; and shall list the resultant records.

Waste Management Plan/Fluid Management Plan - This plan provides the framework for the characterization, storage, accumulation, treatment, and disposal of Sub-Project wastes (NNSA/NSO, 2009).

Field Activity Work Package - The FAWPs provide the safety basis for performing work under the UGTA Health and Safety Plan (NSTec, 2008). The FAWPs document the objectives and technical requirements for the site operations, and site-specific health and safety requirements. These packages include the following:

- Task technical and quality objectives

- Task details, design, construction, and field activity steps

- Intended measurements, data generation, or data acquisition methods, as appropriate

- Scope of data collection and specifics on the data to be collected

- Assessment procedures for confirming that data of the type and quality needed are obtained

- Any limitations on the use of the data that can be identified and documented

- Safety hazard analysis, personal protection equipment, and emergency procedures

\section{B.1.2 Field Documentation}

Participants' field documentation shall be of sufficient detail to facilitate the reconstruction of field activities; documentation shall be traceable to the M\&TE and procedure (including procedure revision) used and, if the reported results are quantitative, a valid calibration. Field personnel shall document activities on a daily activity report or logbook, or on the appropriate form as required by each participating organization. Readiness review documentation may be completed before field activities begin. A staff member other than the person who performed the work, and who is knowledgeable in the area being reviewed, shall review the field-generated data for completeness and 
accuracy. This review should be noted on the reviewed document with an initial and date. Daily activities — such as drilling operations, well development and testing, and water-quality measurements - are communicated by posting morning reports on the ER contractor Field Operations website (which is accessible to NDEP). Records shall be preserved and maintained in accordance with Section A.7.

Participants taking photographs of field activities must have the approval of the NNSA/NSO and be in compliance with NNSS and U.S. Air Force requirements. The photographs shall be processed and stored in accordance with NNSA/NSO security procedures.

\section{B.1.3 Data Collection Activities}

Field activities include, but are not limited to, well drilling and completion (see Section B.1.3.1); well development and testing (see Section B.1.3.2); borehole logging (see Section B.1.3.3); water-level measurements (see Section B.1.3.4); water-quality measurements (see Section B.1.3.5); sample collection (see Section B.1.3.7); and land surveys, surface geophysics, and geologic mapping (see Section B.1.3.6). These activities are performed in accordance with participants' SOPs, FAWPs, and field instructions (see Attachment 1). Attachment 1 also identifies the activity purpose as operational, technical, or regulatory.

Data collection activities are divided into three purposes: operational, technical, and regulatory. Operational activities are used to monitor equipment and processes to ensure they are working normally or within their established parameters (field screening). These activities may involve sampling. Technical activities are used to support the groundwater flow and transport model. These activities generally involve field measurements (water levels, borehole logging) but may require sampling. Regulatory activities require sampling.

\section{B.1.3.1 Well Drilling and Completion}

Participants shall control drilling and completion operations using a combination of SOPs, FAWPs, and statements of works (SOWs) (see Attachment 1). The SOWs communicate the quality requirements to the drilling subcontractor. The $\mathrm{M} \& \mathrm{O}$ contractor is responsible for obtaining well drilling and construction subcontractor services; and for providing oversight for drilling operations, 
including well-drilling design specifications, contract management, and site preparation. The drilling and construction subcontractors shall conduct contracted activities (i.e., well construction and measurements) in accordance with their procedures as directed in the SOW and site-specific FAWPs.

During drilling operations, the ER contractor is responsible for technical oversight and data acquisition. These responsibilities include documentation of well-site operations, water-quality monitoring, drill cuttings collection and handling, cuttings sample description, geophysical logging oversight, fluid management, data management, decontamination, waste management, environmental compliance, depth-to-water measurements, and groundwater sampling. The DRI is responsible for flow and water-quality logs. Flow logging may also be performed by a subcontractor to the M\&O contractor and/or USGS.

The ER contractor is responsible for preparing a well data report that describes the drilling operations and presents preliminary data. The $\mathrm{M} \& \mathrm{O}$ contractor is responsible for preparing the well completion report, which describes geologic and hydrogeologic characterization data and interpretations, as well as the final well construction (as-built) design. The well completion reports present data collected during drilling including, but not limited to, well construction information; borehole logs (e.g., geophysics, flow, lithologic, water quality); preliminary water-level measurements; water production; drilling parameters; and the results of radionuclide (i.e., tritium) monitoring. The DRI provides their final water-quality logs and flow logs to the $\mathrm{M} \& \mathrm{O}$ contractor either by a submittal package or report.

\section{B.1.3.2 Well Development and Testing}

Well development is performed to improve hydraulic efficiency by removing residual fluids and sediments introduced into the borehole during drilling and well construction. Well development progress is assessed by monitoring water-quality parameters, visual observation of well discharge, and changes in hydraulic response.

Operations include logging flow and water quality; measuring water levels; collecting depth-discrete and composite-wellhead (i.e., groundwater characterization) samples; and conducting step-drawdown and constant-rate aquifer tests. The ER contractor is responsible for oversight of well development and testing; the $\mathrm{M} \& \mathrm{O}$ contractor is responsible for providing support for the pumping equipment; and 
DRI is responsible for logging operations. Each participant provides laboratory analysis support for the groundwater characterization samples (see Attachment 1).

The ER contractor is also responsible for preparing well development and testing data and analysis reports that describe the operations along with the analyses of the resulting data (e.g., aquifer test, water chemistry, and isotopic compositions).

\section{B.1.3.3 Borehole Logging}

Geophysical logging is typically conducted in both saturated and unsaturated portions of the borehole at each well. Logging records the geologic, hydrologic, and petrophysical characteristics of rock units within individual boreholes. The logging is conducted by a geophysical logging subcontractor to the $\mathrm{M} \& \mathrm{O}$ contractor. The $\mathrm{M} \& \mathrm{O}$ contractor is responsible for ensuring that the quality and data deliverable requirements are specified in the SOW. The ER contractor is responsible for oversight for the borehole logging activities (see Attachment 1). Borehole logging is also performed by DRI, and flow logging may be performed by USGS (see Attachment 1).

Lithologic/stratigraphic logs are produced by the ER and M\&O contractors. The ER contractor is responsible for geologic data collection and for determining the lithologic characteristics of the geologic units penetrated during drilling (i.e., preliminary field log). The M\&O contractor is responsible for following up with a detailed lithologic/stratigraphic log by evaluating the core, drill cuttings, and geophysical logs at the USGS Core Library in Mercury, Nevada. The M\&O contractor also incorporates the results of petrographic (thin sections) and laboratory analyses (x-ray diffraction [XRD] and X-ray fluorescence $[\mathrm{XRF}]$ ) into the final lithologic and stratigraphic log.

Geologic samples from boreholes (drill cuttings and sidewall cores) and outcrops are archived at the USGS Core Library in Mercury, Nevada. This facility provides a secure and environmentally controlled repository for long-term storage of Sub-Project-derived samples. The ER contractor and Core Library management procedures address sample submission, inventory, ownership, use, and final disposition of samples. Before admission, samples must have documented radiological surveys (see Attachment 1 for procedures). Only authorized personnel are allowed access to samples for studies/analyses. 
The well completion report, prepared by the $\mathrm{M} \& \mathrm{O}$ contractor, presents the final borehole logs generated during drilling. The $\mathrm{M} \& \mathrm{O}$ contractor is responsible for logging data archival.

\section{B.1.3.4 Water-Level Measurements}

Multiple participants are responsible for water-level measurements, depending on the activity associated with the measurement. The ER contractor is responsible for measuring water levels during well drilling, completion, development, and testing. The ER contractor and USGS are primarily responsible for long-term water-level monitoring, although other participants (e.g., DRI) may also perform these measurements (see Attachment 1). The USGS is responsible for maintaining the reference steel tape used for calibrating electric tapes used for water-level measurements. Water-level measurements are maintained in a database and are compiled in data reports generally prepared by the participant responsible for the measurements.

\section{B.1.3.5 Water-Quality Measurements}

The ER contractor is responsible for performing water-quality measurements on discrete samples during drilling and well development and testing. The groundwater is monitored for tritium, $\mathrm{pH}$, electrical conductivity, dissolved oxygen, temperature, turbidity, and bromide concentration to assess the progress of well development (see Attachment 1).

\section{B.1.3.6 Land Surveys, Surface Geophysics, and Geologic Mapping}

The $\mathrm{M} \& \mathrm{O}$ contractor is responsible for performing land surveys for newly drilled wells according to a series of SOPs (see Attachment 1). The survey results are documented in the well completion report. Additional land surveys may be performed by other participants (ER contractor and USGS) according to the SOPs presented in Attachment 1.

Surface geophysical measurements and geologic mapping may also be performed by the USGS, $\mathrm{M} \& \mathrm{O}$ contractor, or subcontractor according to the SOPs presented in Attachment 1. The data shall be documented in the associated data collection activity reports. 


\section{B.1.3.7 Sample Collection}

Samples are collected for different reasons throughout field activities. Regulatory samples are analyzed to (1) monitor and/or evaluate potential contamination from the nuclear events with respect to SDWA (CFR, 2010a) (see Attachment 2, Table 2-2) and (2) satisfy requirements for fluid and waste management (see Attachment 2, Table 2-3). Technical samples are collected to support groundwater flow and transport modeling - for instance, those samples used to evaluate flow paths and estimate travel times (see Attachment 2, Table 2-4). Operational samples are generally analyzed on site. For example, the periodic measurements of lithium bromide, $\mathrm{pH}$, temperature, and electrical conductivity verify that the well has been sufficiently purged of drilling fluids.

The ER contractor is responsible for collecting samples during drilling and well development testing (see Attachment 1). Lawrence Livermore National Laboratory is responsible for collecting water samples from hot wells. Sample collection may be conducted by other participants, as described in the associated plans and/or FAWPs. The organization collecting samples is responsible for (1) obtaining the samples; (2) delivering samples; and (3) completing paperwork for sample tracking.

To prevent cross-contamination of samples, equipment coming into contact with samples shall be rinsed before use, between sampling locations, and before leaving the site. Rinsing activities shall be performed and documented in accordance with the participating organization's approved SOPs.

Drilling fluids, water production from the well, and sump volumes and levels shall be monitored and recorded on the appropriate forms. The following subsections identify the requirements for regulatory samples. Some of the sections may be applied to operational and technical samples dependent on the participants SOPs.

\section{B.1.3.7.1 Sample Labels and Identification}

Sample labels shall be completed using indelible ink and be securely affixed to the containers. Sample information and data are keyed to each sample's unique number. Sample labels shall contain the following information as applicable:

- Project name

- Unique sample number 
- Sampling date and time (24-hour clock)

- Sample medium

- Requested analyses

- Name of the individual collecting the sample

- Sample preservation

Each sample number shall be indicated on both the container and the sample collection forms. For samples requiring multiple containers, the same sample number shall be on each container. Labels that are not plastic coated and have the potential to smear or deteriorate shall be covered with clear tape.

\section{B.1.3.7.2 Sample Handling}

The appropriate sample containers, preservation procedures, and holding times for specific analyses are specified in Attachment 2, Table 2-1. Where applicable, sample containers shall be certified as clean and shall remain sealed until ready for use. Attachment 2, Table 2-1 lists the parameters and analytical methods for commercial analytical laboratory services and Sub-Project participants. Modifications to the parameters and analytical methods listed in Attachment 2, Table 2-1 can be addressed on a case-by-case basis.

Participants are to conduct operations in compliance with applicable federal, state, and local laws and regulations. U.S. Department of Transportation (DOT) regulations provide for the classification, packaging, marking, labeling, placarding, preparation of shipping papers, and transport of hazardous materials. Hazardous materials defined under Title 49 Code of Federal Regulations, Parts 171 to 177 (CFR, 2010b), include radioactive materials as Class 7 hazardous materials.

\section{B.1.3.7.3 Chain of Custody}

Chain of custody forms initiated for each field sample collected shall provide the traceability of possession from the time the samples are collected until disposal. A sample is considered to be in custody if it meets any of the following criteria:

- Is in a person's physical possession

- Is in a person's unobstructed view after being in the person's physical possession

- Is in a secured area to prevent tampering after having been in the person's physical possession

- Is in a designated secured area, restricted to authorized personnel only

- Is in secure packaging and sealed with a custody seal during shipment to laboratory 
To ensure that tampering is easily detectable, each sample container shall be sealed with a custody seal that is initialed and dated by the sample custodian before it leaves the sample collection site. The seal shall be placed such that the container cannot be opened without breaking the seal.

Sampling events shall be monitored periodically to ensure that custody procedures and records are being properly implemented. The sample custodian is responsible for sample custody until the sample is relinquished to another individual or a secure storage area via the chain of custody form. The chain of custody form does not document transfers to and from shipping entities. This transfer does not interrupt the chain of custody as long as the package remains sealed. Whenever samples are transferred to a new sample custodian, the new custodian shall sign his or her name, the company name, and the time and date that the transfer occurred. The chain of custody form shall accompany the samples during handling and shipment.

\section{B.1.3.7.4 Field QC Samples}

Field QC samples provide a mechanism for assessing and documenting that the sample-collection process meets the quality objectives in accordance with EPA guidance (EPA, 2009b). Field QC samples shall be submitted to the appropriate laboratory without indicating that they are QC samples to minimize handling, analysis, and data-evaluation bias. Collection and documentation of field QC samples shall be in accordance with approved procedures and plans. Field QC samples include, as applicable, equipment rinsate blanks, field blanks, and field duplicates. Field QC samples shall be collected as specified in SOPs (see Attachment 1).

Blanks - If blank analytical results indicate possible contamination of samples, sample results shall be reviewed to determine whether qualifiers should be assigned to the data or whether the source should be resampled. Blank analyses results shall be maintained with the corresponding sample data in the laboratory records file and reported in the data package.

- Equipment rinsate is collected from the final rinse solution in the equipment rinse process to determine the effectiveness of the process.

- Field blanks should be collected at specified frequencies, which will vary according to the probability of contamination or cross-contamination. Field blanks should be collected as closely in time and space to the sample as possible. 
Field Duplicate Samples - Field duplicates are collected as closely in time and space to the original sample as possible and used to assess sampling and analytical variability. Duplicate collection shall be evenly distributed throughout the sampling event. The field duplicates shall mirror the sampling and analysis of the original sample, and be assigned a unique sample number. Sample management and documentation procedures for duplicates shall be the same as the original samples.

\section{B.1.4 Investigation-Derived Waste}

Investigation-derived waste shall be managed in accordance with DOE Orders, DOT regulations, Resource Conservation and Recovery Act (RCRA) regulations, Nevada laws and regulations, the FFACO, state and DOE agreements, relevant permits, and Sub-Project requirements.

Investigation-derived waste shall be containerized, when possible, pending the results of waste characterization. Investigation-derived waste shall be characterized and disposed of in accordance with approved procedures and the current UGTA Waste Management Plan (NNSA/NSO, 2009).

\section{B.2 Laboratory Analyses}

Laboratories performing analyses for the Sub-Project-including national laboratories, universities, federal entities, and commercial laboratories - shall perform analyses in accordance with SOPs and are subject to periodic assessments by NNSA/NSO. Verification of subcontractor conformance is the responsibility of the organization procuring the subcontract. A table of laboratory SOPs is presented in Attachment 2, Table 2-1 along with the participant responsible for the analysis, sampling information, laboratory quality control (LQC) samples used to determine accuracy and precision (see Section B.2.2), and the performance evaluation programs (PEPs) each laboratory participates in for a given analyte (see Section B.2.3).

Regulatory sample analyses (see Attachment 2, Tables 2-2 and 2-3), when performed for compliance monitoring or developing contaminant boundaries, shall be performed by a laboratory certified by the State of Nevada.

Analytical chemistry data for samples collected by the Sub-Project shall be submitted to the ER contractor and entered into the UGTA geochemistry database. The ER contractor is responsible for updating, maintaining, and controlling the UGTA geochemistry database. 


\section{B.2.1 Sample Storage}

Samples received at the analytical laboratory that have been entered into the sample tracking system shall be placed into a refrigerator or secure area. The methods of storage are generally intended to perform the following:

- Retard biological action.

- Retard hydrolysis of chemical compounds and complexes.

- Reduce volatility of constituents.

- Reduce adsorption effects.

- Reduce light exposure.

Preservation methods, when required, are generally limited to $\mathrm{pH}$ control, preservative addition, and refrigeration (see Attachment 2, Table 2-1). The possibility of reanalysis requires that proper environmental control for post-analysis samples be provided. Sample storage procedures shall be documented and described in laboratory-specific SOPs. The samples shall be properly disposed of once analyses have been completed and the sample is no longer needed.

\section{B.2.2 Laboratory Quality Control Samples}

The possible LQC samples include laboratory control samples (LCSs), method blanks, surrogate-spike samples, laboratory replicates, and matrix spikes. The LQC samples associated with each analyte are dependent on the analytical method (see Attachment 2, Table 2-1) and are defined in individual SOPs. If LQC sample results are outside statistical control limits, corrective action(s) shall be performed in accordance with the laboratory's SOPs. The laboratory narrative must discuss any nonconformances, their causes, and the resulting corrective actions. If laboratory SOPs require LQC samples to be analyzed at the frequency other than those listed in the following sections, the laboratory SOP shall be followed.

\section{B.2.2.1 Laboratory Control Samples}

The LCSs shall be carried throughout the sample preparation and analysis procedures to assess laboratory accuracy and precision. The LCSs shall be analyzed concurrently with the analytical batch for each analyte of interest and shall be prepared from standards independent of the calibration standard. Control limits for recovery shall be established. Results of LCS analyses shall be reported as the RPD or percent recovery, and included with the associated analytical report. 


\section{B.2.2.2 Method Blanks}

Method blanks shall be analyzed by the laboratory to check for contamination and interference from reagents used in the analytical method. A method blank shall be concurrently prepared and analyzed for each analyte of interest for each analytical batch. Method blank data shall be reported in the same units as the corresponding environmental samples, and the results shall be included with each analytical report.

\section{B.2.2.3 Laboratory Replicate Samples}

Two or more aliquots of the same sample shall be prepared and analyzed, and the results will be used to calculate the precision. Precision shall be reported as RPD or as the relative standard deviation. Replicate analyses may be performed for every 20 samples.

\section{B.2.2.4 Matrix Spike Samples}

Matrix spike samples shall be analyzed by the laboratory to determine interferences of the sample matrix. A separate sample aliquot shall be spiked with the analytes of interest and analyzed with every 20 samples or, if fewer than 20 samples were collected, at least one of the samples shall be spiked. Results of the matrix spike samples shall be reported as RPD or percent recovery, and included with the analytical report.

\section{B.2.3 Performance Evaluation Programs}

Analytical laboratories shall participate in PEPs appropriate for the analyses performed. Performance shall be summarized in the annual QA report. Some Sub-Project parameters do not have an available PEP; therefore, a graded approach to this requirement is described in the following subsections.

\section{B.2.3.1 Parameters with Established PEPs}

If a PEP exists for a parameter, annual participation is required for at least one Sub-Project laboratory. These PEPs may be parameter based or method based. Some laboratories participate in PEPs that are available on an irregular basis. These program results shall be reviewed in the years performed and shall satisfy the PEP requirement. 


\section{B.2.3.2 Interlaboratory Comparisons}

Interlaboratory comparisons shall be performed for parameters not included in a PEP but regularly analyzed by two or more independent laboratories. This includes parameters involved in a PEP for one laboratory but not the other. Annual interlaboratory comparisons, whereby a sample (duplicate, split, or prepared) is analyzed by a minimum of two laboratories, may also substitute for a PEP.

The ER contractor shall review the analytical results to ensure that the values submitted by multiple independent laboratories agree within the stated acceptance criteria (see Attachment 2, Table 2-1). If individual analyses meet this criterion, they shall be considered verified and shall be retained in the database without need of further documentation. If individual analyses do not meet this criterion, results for the noncompliant analyte shall be flagged in the UGTA geochemistry database, and an effort shall be made to determine the source of the discrepancy as follows:

1. The labs shall recheck their submission for errors in data transcription, data reduction, or data acquisition.

2. Participant laboratories shall recheck that sample labeling, handling, and tracking procedures were followed; the correct water samples were analyzed; and QC measures were met.

3. If the reason for the discrepancy is not identified, the consistency of the reported values with previously analyzed samples from the same well (if available) or from the same hydrostratigraphic units (HSUs) in nearby wells (if samples in question are from a newly developed well) shall be assessed.

4. If the reason for the discrepancy is not identified, additional analyses shall be performed if a sample is available and holding times have not been exceeded.

If this process identifies an error that resolves the discrepancy, the responsible laboratory shall correct and resubmit the data; the revised results shall be identified as the superseding results. A brief explanation shall be included with the resubmission and documented in the comment field of the database.

The laboratory responsible for the discrepancy shall provide written documentation of the causes for the data discrepancy, the measures taken to ensure that the problems have been rectified, and the 
corrective action to ensure that the problem shall not recur. Values not within the stated acceptance criteria will be identified as "not consistent" in the UGTA geochemistry database, and a comment identifying the discrepancy shall be entered.

\section{B.2.3.3 Data Evaluation}

Data shall be evaluated for those parameters not included in a PEP or interlaboratory comparison. The evaluation shall include a review of the SOPs (sample collection and analytical) and results (e.g., LQC, instrument calibration results, analytical, data verification, and validation). The evaluation shall be performed by a subject matter expert and documented in accordance with Section A.7.

\section{B.2.4 Analytical Data Documentation}

Participants and subcontractors are responsible for preparing data reports that summarize the results of analyses and data packages that include the following:

- Sample receipt and tracking documentation, including identification of the organization and individuals performing the analysis; and dates of sample receipt, preparation (if applicable), and analysis.

- Quality control data, as appropriate for the methods used, including (as applicable) matrix spikes, recovery percentages, precision and accuracy data, laboratory blank data, and identification of any nonconformance that may have affected the laboratory's measurement system during the time period in which the analysis was performed.

- Analytical results or data deliverables, including reduced data, detection limits, and identification of data qualifiers.

Hard-copy records are required from the commercial laboratories (see Attachment 2, Table 2-1). Hard-copy or electronic records are satisfactory for the other laboratories. These requirements, as well as QA and technical requirements, for the subcontracted laboratories are specified in the SOW.

\section{B.2.5 Verification and Validation of Analytical Data}

Data verification shall be performed to evaluate the completeness, correctness, and conformance of each dataset against the SOP and/or contractual requirements. Data verification shall evaluate how 
closely the procedures were followed during data generation. Data validation shall be performed to determine the analytical quality of the dataset. Data validation criteria are based upon the quality controls described in specified analytical methods and the laboratory's SOPs. The extent of data verification and validation requirements are dependent on whether the samples are regulatory or non-regulatory (technical and operational) (Section B.1.3.7). Data must be scientifically valid, defensible, and of known precision and accuracy. The data should be of sufficient known quality to withstand scientific and legal challenge relative to the use for which the data are obtained.

\section{B.2.5.1 Non-regulatory Data}

Verification of non-regulatory data shall consist of reviewing data for completeness, required LQC results, chain of custody forms, and case narratives that describe any issues related to the sample analyses. Participants shall verify their own analytical data. Validation of non-regulatory data shall include evaluating and qualifying results based on holding times and the results of the LQC samples, as appropriate to the methods used. Data validation is also achieved through the use of interlaboratory comparisons (Section B.2.3.2) or data evaluations (Section B.2.3.3).

\section{B.2.5.2 Regulatory Data}

Verification and validation of data used for regulatory purposes (e.g., compliance monitoring or developing the contaminant boundary) shall be performed by the ER contractor in accordance with the following Standards-Based Management System (SBMS) subject areas (N-I, 2011):

- “Tier I Review - Data Verification"

- "Tier II Chemical Data Review - Data Validation"

- "Tier II Radiological Data Review - Data Validation"

Verification and validation shall include the process described for non-regulatory data. Verification shall also include a review of raw data and a check of the calculation of sample results. Five percent of validated samples shall be validated by a third party. Sample results used for validation shall be selected by use of a random number generator or may be selected by project management in cases where special criteria exist. 


\section{B.3 Laboratory Studies}

The quality and integrity of laboratory studies shall be ensured through participant procedures, plans, qualified personnel, and appropriate tools and calibrated equipment. The plans or procedures shall specify the DQI requirements (Section A.5.2) to ensure that objectives of the study are obtained. Participants shall document the results of laboratory studies, including an evaluation stating whether the DQIs were met.

\section{B.4 Non-direct Data}

The source of these data shall be evaluated for acceptability before their use. The approach, documentation, and review associated with this evaluation are described in Sections A.8.1.1 through A.8.1.3. After the data source is accepted, data records shall be managed in accordance with Section A.7. Data shall be evaluated with respect to quality as described in Section A.8.2; and if used and not collected from within the CAU of interest, data shall be evaluated for transferability as described in Section A.8.3.

\section{B.5 Groundwater Flow and Transport Modeling}

Groundwater flow and transport modeling begins with compiling site characterization data and relevant information to provide a technical basis for the model. Based on this information, conceptual models are developed to describe the general geologic and hydrogeologic characteristics of the system and the various flow and transport system processes of interest. Construction of numerical flow and transport models is based on the conceptual model (Figure B-1).

This section outlines the documentation and requirements associated with development, calibration, uncertainty analysis, and sensitivity analysis of the CAU groundwater flow and transport models (Figure B-1). The specific approaches to modeling flow and transport through the hydrogeologic system, including the underground test cavities for each CAU model, may be presented in a model approach/strategy document. Flow and transport modeling shall be documented in report(s) produced by the responsible participant. 


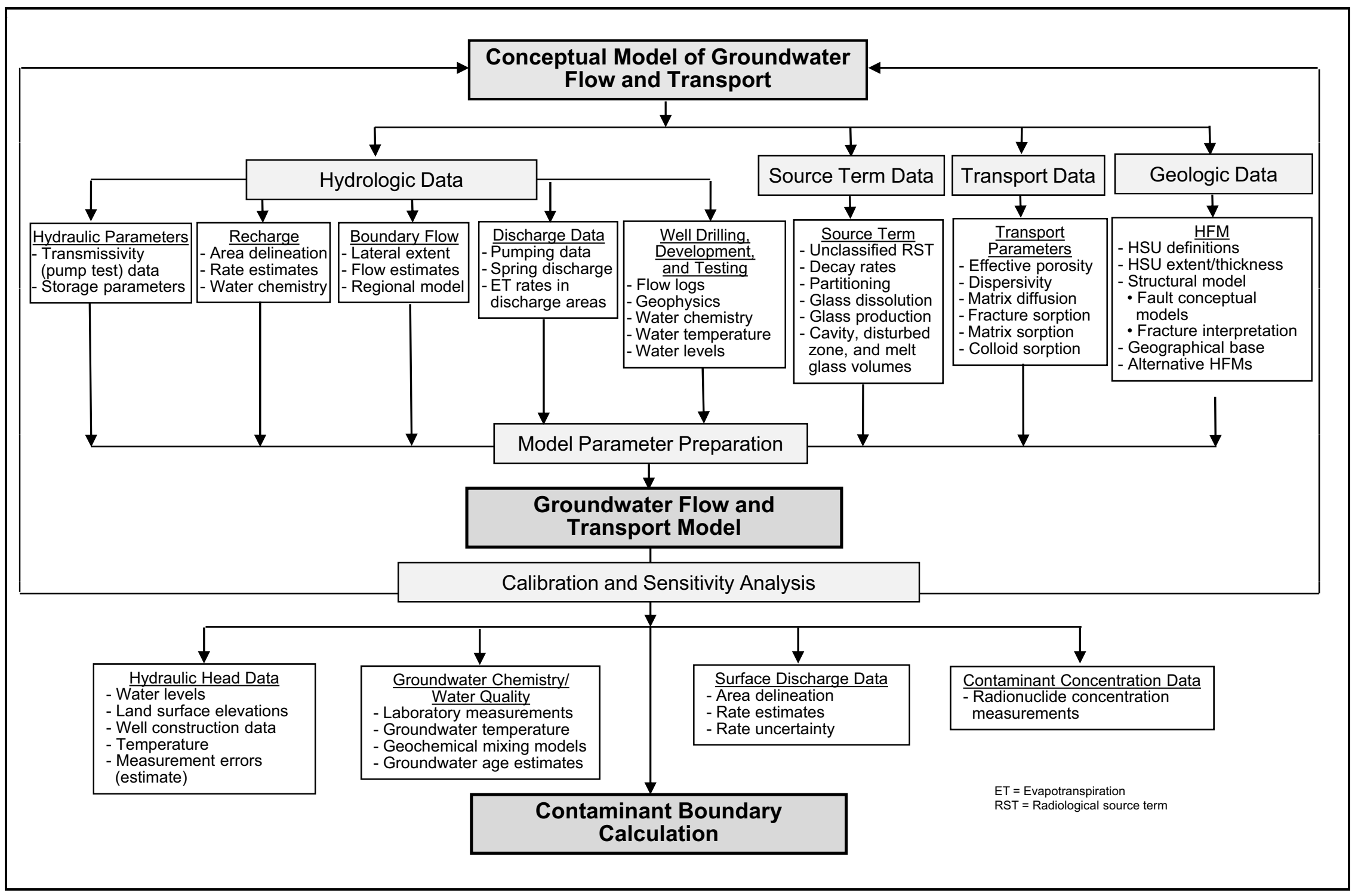

Figure B-1

Groundwater Flow and Transport Modeling Parameters

\author{
UNCONTROLLED When Printed
}




\section{B.5.1 Model Parameters}

Parameters used for groundwater flow and transport model development, shown in Figure B-1, are derived from measurements, laboratory studies, and analyses performed by the Sub-Project and/or from data obtained from other sources (i.e., non-direct data). The documentation of processing, calculating, characterizing, or applying data shall be included in the documents described in the following subsections. These documents are reviewed both internally and externally (see Section C.4).

\section{B.5.1.1 Hydrostratigraphic Framework Model}

Geologic data describing the stratigraphic and structural framework are translated into geologic models or HFMs (Figure B-2). As required by the FFACO (1996, as amended), different geologic conceptual models are evaluated as part of assessing uncertainty. This can include, but is not limited to, assessing the effects of rock alteration, conceptual models of faults and fractures, and uncertainty in stratigraphic arrangement and continuity. The $\mathrm{M} \& \mathrm{O}$ contractor is responsible for developing the HFM documents. These documents describe how the HFM and alternatives were developed, describe the models, and document the data sources.

\section{B.5.1.2 Hydrologic Data}

Hydrologic data include hydraulic parameters, recharge, lateral boundary flow, and other measurements obtained during well drilling, development, and testing (Figure B-1). A CAU-specific hydrologic data document presents hydrologic data and the supporting information used to develop the groundwater flow and transport model; data quality assessments; data analyses to derive expected values or probability distributions; and hydrologic-parameter uncertainty estimates.

\section{B.5.1.3 Transport Parameters}

Transport parameters that may be used for transport simulations include effective porosity, dispersivity, matrix diffusion, matrix sorption, fracture sorption, and colloidal transport. A CAU-specific transport parameter document describes transport parameters and the supporting information used to develop the groundwater flow and transport model; data quality assessments; data analyses to derive expected values or probability distributions; and transport-parameter uncertainty estimates. 


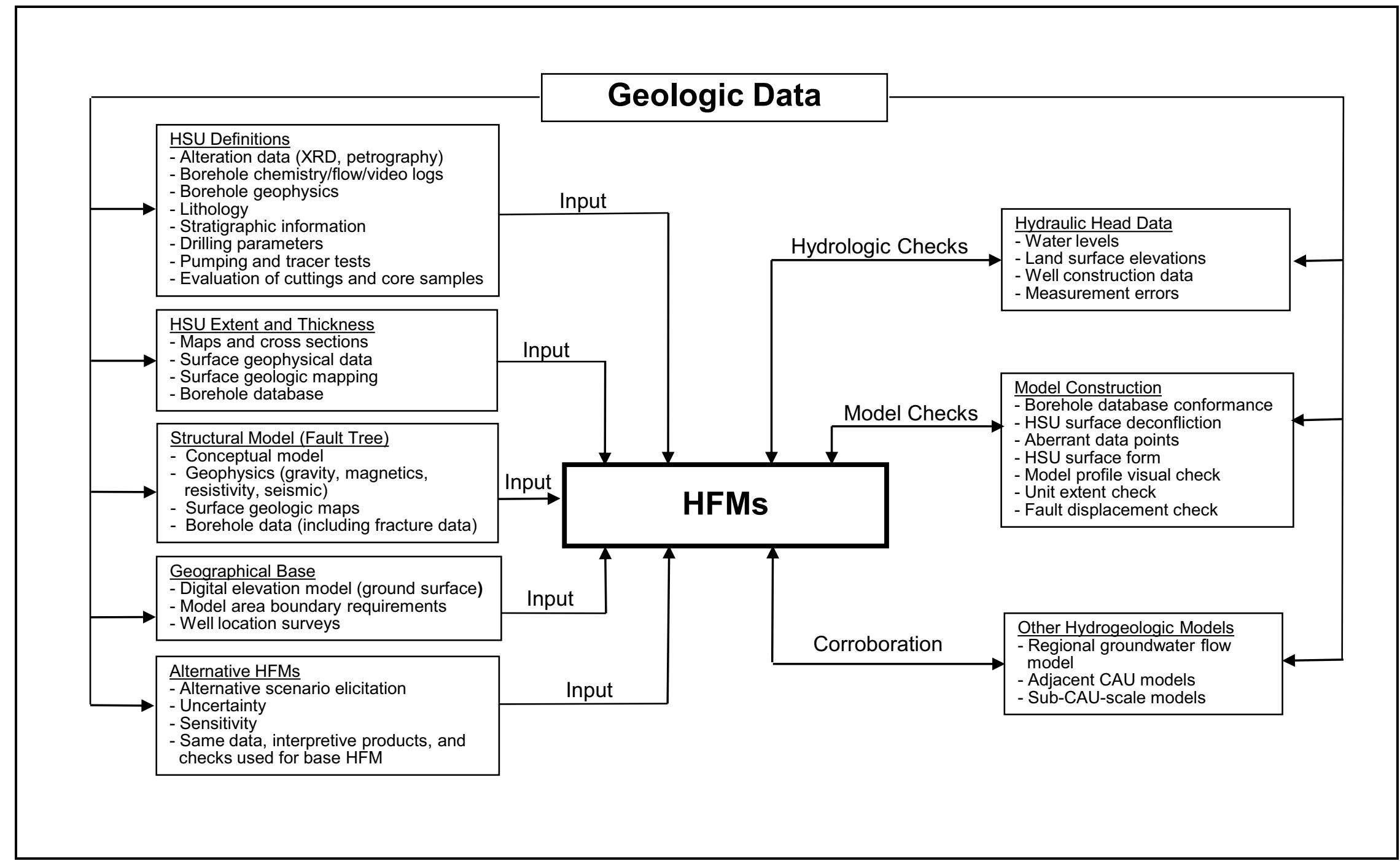

Figure B-2

HFM Modeling Parameters and Process 


\section{B.5.1.4 Source Term Data}

A source term document is prepared for each CAU that describes development of simplified models or the conceptual models used for implementing source terms for the flow and transport models. The document also describes compilation and review of available information and data relating to the unclassified source term. The FFACO (1996, as amended) requires the use of the inventory and inventory uncertainty from the Nevada Test Site Radionuclide Inventory, 1951-1992 (Bowen et al., 2001).

\section{B.5.2 Model Parameter Preparation}

Data used to derive model parameter values for flow and transport models shall be evaluated for quality before use (Section A.8.2). Non-direct data shall be evaluated for acceptability before use (Section A.8.1). Data collected from a location outside of the model area shall be evaluated for transferability before use (Section A.8.3).

Uncertainty, including both natural variability and knowledge uncertainty, is associated with all parameters. These uncertainty components include measurement uncertainty, and natural or non-reducible parameter variability; data limitations; and conceptual model limitations. Uncertainty in parameters is often quantified by developing distributions of values (probability distribution functions) for the parameters rather than using a single value. These distributions represent both the range and the likelihood of occurrence of a particular parameter value. The distribution development method varies depending on the availability of relevant data (distribution fitting) or subjective process knowledge. General guidelines for assigning probability distributions suggested by Mishra (2002) may be used in the groundwater flow and transport models.

Preparation of model parameter data is documented in the various data documents (hydrologic data, transport parameter, and source term) as well as the final flow and transport modeling reports. During the CADD/CAP stage, changes to parameters shall be documented in an addendum or, if requesting movement to the $\mathrm{CR}$ stage, in a summary report. Changes during the $\mathrm{CR}$ stage shall be documented in a summary report or CR addendum. 


\section{B.5.3 Model Calibration}

Model calibration refines a model until it corresponds within desired criteria of observations of a system (ASTM, 1993). This process is used to gain confidence in the model for making decisions. Components of a groundwater flow model that may require calibration include, but are not limited to, HFM, boundary conditions, recharge, hydraulic properties, and transport parameters. Calibration is generally an iterative process that involves comparing a model result to calibration targets. Models are typically calibrated using trial and error and/or automated techniques. Model scope and data availability will be used to guide the selection and application of the specific calibration procedure. The following are example calibration approaches.

Visual Evaluations - Visual comparison of the various HFM units with drill-hole data; surface-grid points with HSU layers in the model; mapped versus simulated potentiometric surfaces; and scatter plots of simulated and measured water levels and flows (e.g., Oasis Valley discharge). Also residual (difference between observed and simulated values) maps examining spatial patterns of model agreement with calibration targets and histograms of weighted residuals may be visually inspected.

Quantitative Evaluations - Quantitative evaluation of potentiometric head residuals; correlation among head residuals, flow residuals (the difference between observed and simulated volumetric flows used in model calibration), concentration residuals, and minimum and maximum residuals; total model objective function; and/or objective functions of particular calibration target datasets. The influence of model parameters can also be quantitatively evaluated. For instance, if a particular unit's permeability consistently requires systematic adjustment relative to its expected value, it may be indicative of a model structure problem or an incorrect expected value.

Conceptual Evaluations - Testing the model with the conceptual model of the system. For example:

- Geologic and hydrogeologic conventions are honored.

- Direction and/or velocity of groundwater flow are consistent with geochemical age dates.

- Direction of groundwater flow is consistent with spatial distribution of major-ion chemistry. 
- Hydraulic conductivity is within reasonable range of aquifer test data.

- Permeability is consistent with the conceptual model (e.g., zeolitic units are less permeable than fractured-rock units).

The calibration process is documented in the groundwater flow and transport model document, or subsequent modeling report developed during the CADD/CAP or CR stage. Documentation shall include the following:

- Specific approaches used for model calibration

- Rationale for selecting particular model calibration approaches

- Calibration results

- Comparison of initial versus final unit properties (e.g., porosity, permeability)

- How the final properties relate to the conceptual model

In addition, the model developer shall document why the model is a reasonable approximation of the in situ conditions. Independent lines of evidence such as regional studies, other CAU studies, geochemistry, or thermal observations may be used.

\section{B.5.4 Sensitivity Analysis}

Modelers use a comprehensive sensitivity analysis to build confidence in the model results and to aid in the uncertainty component identification. Sensitivity analyses can be used during model calibration and when assessing simulation results. Sensitivity analysis will consider the purpose of the analysis and focus on the hypothesis to be tested. Sensitivity analysis is an area of active research and new ideas, and analyses may be developed that may be beneficial to the Sub-Project; therefore, the following list is not prescriptive but illustrative. The applicability of sensitivity analysis techniques can vary depending on the linearity or non-linearity of the model, the goal of the analysis, and the sensitivity of model response. The following sensitivity analyses may be used to gauge the sensitivity of model response:

- Assessment of parameter correlations and covariance

- Parameter sensitivity using sensitivity coefficients defined as the change in output divided by the change in input at a reference point

- Contingency tables, including chi-square and entropy statistics for transport parameter distributions 
- Classification-tree analysis

- Stepwise regression

Sensitivity analysis methods are quantitative in nature, but it is also important to consider their consistency with the conceptual model. The sensitivity analysis approach selected by the modeler shall be described and justified with respect to the model purpose in the flow and transport model document (or subsequent modeling documents).

\section{B.5.5 Uncertainty Analysis}

Uncertainty analysis describes the model response with respect to the uncertainty in input parameters. Model parameter uncertainty can be examined using the null-space Monte Carlo method implemented in parameter estimation software (PEST), or similar methods. Like sensitivity analysis, uncertainty analysis (particularly with respect to conceptual models) is an area of developing approaches, and the examples (drawn from Sub-Project applications) below are not prescriptive but illustrative. Individual model components, their associated uncertainties, and approaches used may include the following:

- Hydrostratigraphic Framework Models - Alternative HFMs as components of conceptual uncertainty

- Groundwater Flow Models - Null-space Monte Carlo evaluation of flow model parameter uncertainty

- Groundwater Transport Models - Latin hypercube sampling of parameter values ranges including matrix and effective porosity, distribution coefficient $\left(\mathrm{K}_{\mathrm{d}}\right)$, fracture aperture, and matrix diffusion

- Source Term Models - Latin hypercube sampling of parameters including inventory, $\mathrm{K}_{\mathrm{d}}$, nuclear melt-glass dissolution, and exchange volume radius and properties

The Sub-Project uncertainty approach includes both parameter and conceptual uncertainty. For instance, the Frenchman Flat Phase I peer review (N-I, 2010) commented that the geologic model used a general concept that had uncertainty in its application. This uncertainty was later evaluated with different HFMs, which form a discrete test of uncertainty. It is not prescribed that conceptual uncertainty be in the form of discrete tests - the evaluation of this type of uncertainty is still relatively 
new and is highly site specific. The method applicability to the uncertainty type shall be described and justified by the modeler with respect to the model purpose.

\section{B.5.6 Contaminant Boundary Calculations}

The contaminant boundary calculation procedure involves the following steps:

1. Selecting a groundwater flow model (which may include HFM and/or parameterization alternatives) (NNES, 2010).

2. Assigning the hydrologic source term(s) using consistent groundwater flow rates observed in the selected flow model-if the test is not completely in the unsaturated zone (NNES, 2010).

3. Executing radionuclide transport calculations for flow model results, including consideration of source term and transport uncertainties (NNES, 2010).

4. Collecting contaminant concentration distributions (in space) at regular, specified output times over a 1,000-year period, for all simulations of the transport model (Daniels and Tompson, 2003; NNES, 2010).

5. Converting contaminant concentration distributions to the radiological standards of the SDWA (CFR, 2010a) for each transport model result (Daniels and Tompson, 2003; NNES, 2010).

6. Determining spatial locations and times where radiological standards are exceeded for each transport model result (Daniels and Tompson, 2003; NNES, 2010).

7. Logging the frequency that radiological standards are exceeded at each model element location, regardless of time, over the entire series of transport model simulations (Daniels and Tompson, 2003; NNES, 2010).

8. Identifying model element locations where the frequency that radiological standards are exceeded is greater than 5 percent of the total number of transport simulations. Elements meeting this criterion are then considered within the contaminant boundary at 95th percentile; elements not meeting this criterion are considered outside the boundary (Daniels and Tompson, 2003; NNES, 2010).

9. Repeating the described procedural steps for multiple alternative models. 


\section{B.6 Model Evaluation}

Model evaluation continues through the UGTA corrective action strategy stages but is the focus of the CADD/CAP stage. During this stage, additional data will be gathered to increase confidence in the conceptual model and flow and transport model results reliability. Refinements to the model will be documented as addenda to the CADD/CAP or in a summary report.

During the CR stage, further evaluation of the model will occur as new data are gathered. These evaluations will be documented as addenda to the CR or in a summary report.

\section{B.7 Configuration Control}

Models accepted by NDEP (before the CADD/CAP and CR stages) shall be archived and placed under configuration control (Section A.9.6). The model documentation shall be sufficient to ensure traceability and reproducibility.

- Traceability is achieved to the degree that a reviewer with sufficient training and access to supporting information is able to follow the flow of information in a model from source data through conceptualization, parameterization, code input, code calculations, and code output, and ultimately to the results reported in released documents.

- Reproducibility is achieved when it is demonstrated that a model can be restored to any check point in time during the model maintenance period when it was used to produce reported results and can be rerun to obtain the reported results.

Documentation shall include the following:

- Input data and source identification

- Identification of model assumptions and limitations (e.g., valid ranges of model application, spatial and temporal scaling)

- Model executable codes, including pre- and post-processors

- Computer calculations, and basis to permit traceability of inputs and outputs

- Final results and output data files

- Identification of the originator(s) and reviewer(s) 


\section{Assessment and Oversight}

\section{C.1 Assessment}

Several decision points require assessment of work performed throughout the various stages of the UGTA corrective action strategy. To increase confidence in the decisions, multiple assessments are performed by the Sub-Project, including management self-assessments, oversight assessments, technical review of project activities, and document review. These assessments are described within this section.

\section{C.1.1 NDEP and NNSA/NSO Decision Points}

The FFACO (1996, as amended) mandates several decision points within the UGTA strategy. If the work does not pass the assessment, additional work must be performed before proceeding to the next stage in the UGTA strategy.

\section{C.1.2 Management Self-Assessments}

Participant management shall conduct at least one assessment of their programs or documents annually. The emphasis of management self-assessments is to evaluate the implementation of the QA program and identify process improvements. Participant management should conduct assessments focusing on issues such as the following:

- Adequacy of implementation of the QA program, with emphasis on quality improvement

- Management biases or organizational barriers that impede the improvement process

- Participating organization's structure, staffing, and physical facilities

- Training programs

The results of the assessment shall be documented in a report and issued to the appropriate managers. Participants shall ensure the timely follow-up of corrective actions, including an evaluation of the effectiveness of management's actions. Results of the management self-assessment should be entered into a tracking system for the purposes of identifying trends and lessons learned. 


\section{C.1.3 Oversight Assessments}

Oversight assessments shall be performed periodically by NNSA/NSO personnel, or their designees, to verify compliance with applicable quality requirements, DOE policies, and procedures. Assessments shall be conducted in accordance with NSO Order 226.XC, Assessment and Oversight (NNSA/NSO, 2010).

\section{C.2 Technical Reviews}

Pre-Emptive Review Committees (Section A.3.5.2) and Topical Committees (Section A.3.5.3) support the Sub-Project by providing technical reviews of various products, including data, documents, and analyses. These committees ensure that the work is technically adequate, competently performed, and properly documented; and satisfies established quality requirements through the review of assumptions, calculations, extrapolations, alternative interpretations, methods, acceptance criteria, and conclusions pertaining to the data or models. Technical review records may include, but are not limited to, meeting minutes, agendas, presentations, comments, comment responses, recommendations, white papers, decisions, action items, and technical basis documents.

\section{C.3 Peer Review}

A formal external, independent peer review panel shall be formed by NNSA/NSO at the end of the CAI to review the flow and transport model results. The peer review evaluates whether assumptions, methods, and conclusions derived from the models are based on sound scientific principles; and examines the scientific appropriateness of the model(s) for informing the regulatory decision. The peer review panel consists of nationally recognized experts in geology, hydrology, groundwater modeling, geochemistry and other related fields. The review panel shall, at a minimum, answer the following questions in the peer review final report:

- Are the modeling approaches, assumptions, and model results for the CAU consistent with the use of modeling studies as a decision tool for resolution of environmental regulatory requirements?

- Do the modeling results adequately account for uncertainty in models of flow and transport in the hydrological setting of the CAU?

- Are the supporting geologic, hydrologic, and geochemical data and modeling results adequate for a transition to CAU model evaluation? 
The NNSA/NSO and NDEP will consider the peer review report when deciding whether there is sufficient confidence in the model results to proceed to the CADD/CAP stage. The NNSA/NSO may request a peer review at any time.

\section{C.4 Document Review and Issuance}

Documents issued by participants may be reviewed for internal organizational use only; internal review (Pre-Emptive Review Committees, Topical Committees, Contract Managers) before finalization; external review (i.e., NDEP) before approval; or public release. Additionally, participants share and exchange information during document and model development. The following subsections outline the minimum requirements for review and issuance. Documents should adhere to the participant's corporate style and usage rules; or default to the GPO Style Manual, the Chicago Manual of Style, or Merriam-Webster dictionary.

Participants shall maintain the completed Document Review Sheets (DRSs) as records. Each iteration of FFACO-mandated documents (Draft, Rev. 0, and Rev. 1) shall be submitted to the ER contractor Central Files, NNSA/NSO Environmental Management Records, and the NNSA/NSO read file.

\section{C.4.1 Input to Other Participant Documents}

When transmitting information, professional judgment, data, code, models, or inputs to another participant, the originating participant shall ensure that the source(s) of the transmittal is identified and traceable. The originating participant shall also identify any limitations or qualifiers for the data or information to the receiving entity.

\section{C.4.2 Internal Participant Use Only}

Contract Managers shall ensure documents issued by Sub-Project participants for internal use only (i.e., plans and procedures) are developed and issued in accordance with their procedures. Internal participant documents may be reviewed by other participants outside the internal review process described in the following section. These documents are published as internal participant documents (e.g., data reports) but may be distributed to other Sub-Project participants. 


\section{C.4.3 Internal Review}

The Contract Manager shall ensure the following before transmitting a draft document to Sub-Project participants for review:

- Includes the footer "This is a draft, predecisional document and is not releasable to the public" on the document cover and on each internal page. (If the document is FFACO mandated, the footer should read "This is a draft, predecisional U.S. Department of Energy document and is not releasable to the public.")

- Has been reviewed by a Derivative Classifier of the originating contractor.

- Is distributed as an unsigned and uncontrolled document.

- Has been internally reviewed for quality requirements identified in internal planning documents or procedures, technical adequacy, accuracy, and completeness.

- If the document is FFACO mandated (CAIP, CADD/CAP), it must also follow the approved FFACO outline (FFACO, 1996; as amended). The outline can be modified through agreement between NNSA/NSO and NDEP.

The draft document is reviewed by, at a minimum, NNSA/NSO personnel including the FFACO Administrator (if FFACO mandated), and Pre-Emptive Review Committee or Topical Committee members. Additional reviewers may be added by the originating Contract Manager provided the transmittal does not require public release of the document. Specific Pre-Emptive Review Committee members may be identified for limited reviews (e.g., subject matter experts in modeling only).

The document is transmitted with a DRS and due date. Reviewers review the document and record comments on the DRS by the due date. The Contract Managers shall ensure their participants' comments are compiled and appropriate before the due date.

The compiled comments shall be sent to the CAU Pre-Emptive Review Committee Chairperson. The CAU Lead and Chairperson shall screen, compile, and prioritize the comments. The Pre-Emptive Review Committee may undertake comment integration and/or resolution if appropriate. The Pre-Emptive Review Committee's process shall be executed within a time frame consistent with due dates or milestones. The author(s) shall address the comments and modify the document as directed by the committee. 
Once the review comments are addressed, either a final document is issued (if no external review) or a Final Rev. 0 document shall be produced.

\section{C.4.4 External Review}

The originating Contract Manager shall ensure the following regarding the Final Rev. 0 document:

- Has completed an internal review (Section C.4.3).

- Includes the footer "This is a predecisional document and is not releasable to the public" on the document cover and on each internal page. (If the document is FFACO mandated, the footer should read "This is a predecisional U.S. Department of Energy document and is not releasable to the public.")

- Has been reviewed by a Derivative Classifier of the originating contractor.

The Final Rev. 0 document is reviewed by, at a minimum, NNSA/NSO personnel, including the FFACO Administrator and Technical Information Review Panel (TIRP), and NDEP. Additional reviewers may be added by the originating Contract Manager provided the transmittal does not require public release of the document. The document is transmitted with a DRS and due date. Reviewers review the document and record comments on the DRS by the due date.

Once the review comments are addressed, a Final Rev. 1 document for public release is produced.

\section{C.4.5 Public Release}

The Final Rev. 1 document is considered the final document and is submitted to the Federal Sub-Project Director for public distribution. The originating Contract Manager shall ensure the following regarding the document:

- A TIRP-assigned document number is present.

- Includes the footer "Approved for public release; further dissemination unlimited."

The Final Rev. 1 document is reviewed before distribution by, at a minimum, the originating organization Classification Officer and the NNSA/NSO TIRP (NDEP comments and revisions only). 


\section{C.5 Reports to Management}

The participant management shall be informed of quality-related activities through the receipt, review, and/or approval of the following:

- Project-specific plans and procedures

- Assessment reports

- Corrective action requests, corrective actions, and schedules

- Nonconformance reports (NCRs)

In accordance with FFACO, Part VII (1996, as amended), quarterly reports and three-month advance schedules are prepared and submitted to NDEP. The Federal Sub-Project Director shall submit an annual QA report and a list of the current UGTA participants to NDEP. 
This section establishes the methods and responsibilities for identifying, reporting, controlling, and resolving conditions of nonconformance and conditions adverse to quality.

\section{D.1 Stop Work Order}

The NNSA/NSO personnel and Sub-Project participants are authorized and have the responsibility to stop work when a condition adverse to health and safety, quality, or the environment is identified. If the condition is allowed to continue, it could result in personal injury; cause damage to equipment or property; have an adverse impact on mission accomplishment, budget, or schedule; or cause damage to the public and/or environment. If imminent danger exists, a stop work order (SWO) may be verbally imposed. An SWO may be limited to a specific activity, item, or design; or it may be broad in scope and encompass all activities relating to the deficiency or violation. The participant shall notify the Federal Sub-Project Director of SWOs.

Work shall resume only upon completion of the necessary actions specified on the SWO and with approval of the Federal Sub-Project Director, or designee.

\section{D.2 Nonconformance Reporting}

A nonconformance is a deficiency in characteristic, documentation, or procedure that renders the quality of an item or activity unacceptable or indeterminate. The NNSA/NSO encourages personnel to identify and document nonconforming items and processes. It is also NNSA/NSO policy to identify and document nonconforming items and processes in a manner that focuses on solution and discourages fault-finding. This encourages the open identification and resolution of problems. Individuals identifying nonconforming conditions or items are responsible for documenting and reporting the nonconformance. Personnel who are responsible for corrective actions should be notified at the time the nonconformance is identified so corrective measures are taken in a timely manner. 
The NCRs shall be handled in accordance with each participant's internal process. An NCR shall specify the following:

- Originator

- Date of the nonconformance

- NCR number (unique to the originating organization)

- Responsible organization

- Requirement(s)

- Nature of the nonconformance

- Disposition

- Technical justification for disposition

When an NCR affects cost, schedule, or scope, or is a health and safety issue, the Federal Sub-Project Director must be notified.

\section{D.3 Cause}

A cause is the most basic element that (if corrected) shall prevent recurrence of the same, or similar, problem. The participants should conduct a causal analysis when appropriate (e.g., when the understanding of the underlying cause is important to the prevention of similar or related problems). The analysis should be used to gain an understanding of the deficiency, its causes, and the necessary corrective actions to prevent recurrence. The analysis shall be maintained as a record. The level of effort expended should be based on the possible negative consequences of a repeat occurrence of a problem.

\section{D.4 Trend Analysis}

Trend analysis should be performed on nonconforming conditions, deficiencies, root causes, and the results of improvement initiatives to identify possible trends. Participants shall bring adverse trends to the attention of the appropriate management. Positive trends, such as improved performance or cost savings resulting from enhancements or the application of new technology, should be shared to facilitate improvement in other areas or projects. As appropriate, information obtained from trend analyses should be included in a lessons learned or records system. 


\section{D.5 Lessons Learned}

The NNSA/NSO has implemented a lessons learned system established as a focal point for reporting and retrieving important information concerning experiences gained through previous activities. Continuous improvement can be fostered through incorporation of applicable lessons learned into work processes and Sub-Project planning activities, including work plan development, budget development, and strategic planning. The lessons learned program should be used interactively with other management tools such as critiques, assessments, readiness reviews, and evaluations of field activities. 
ASQ, see American Society for Quality.

ASTM, see ASTM International.

American Society for Quality. 2004. Specifications and Guidelines for Quality Systems for Environmental Data Collection and Environmental Technology Programs, ANSI/ASQC E4-2004. Milwaukee, WI.

ASTM International. 1993 (reapproved 2008). Standard Guide for Comparing Ground-Water Flow Model Simulations to Site-Specific Information, ASTM D5490 - 93(2008). Philadelphia, PA.

ASTM International. 1996 (reapproved 2008). Standard Guide for Developing and Evaluating Ground-Water Modeling Codes, ASTM D6025 - 96(2008). Philadelphia, PA.

Bowen, S.M., D.L. Finnegan, J.L. Thompson, C.M. Miller, P.L. Baca, L.F. Olivas, C.G. Geoffrion, D.K. Smith, W. Goishi, B.K. Esser, J.W. Meadows, N. Namboodiri, and J.F. Wild. 2001. Nevada Test Site Radionuclide Inventory, 1951-1992, LA-13859-MS. Los Alamos, NM: Los Alamos National Laboratory.

CFR, see Code of Federal Regulations.

Code of Federal Regulations. 2010a. Title 40 CFR Part 141, "National Primary Drinking Water Regulations." Washington, DC: U.S. Government Printing Office.

Code of Federal Regulations. 2010b. Title 49 CFR Parts 171 to 177, "Hazardous Materials Regulations." Washington, DC: U.S. Government Printing Office.

DOE, see U.S. Department of Energy.

DOE/NV, see U.S. Department of Energy, Nevada Operations Office.

Daniels, J.I., and A.F.B. Tompson. 2003. Technical Basis for Also Using Health-Risk Assessment To Establish Contaminant Boundaries for Corrective Action Units (CAUs) of the Underground Test Area (UGTA) at the Nevada Test Site (NTS), UCRL-TR-201702. Livermore, CA: Lawrence Livermore National Laboratory.

EPA, see U.S. Environmental Protection Agency.

FFACO, see Federal Facility Agreement and Consent Order. 
Federal Facility Agreement and Consent Order. 1996 (as amended March 2010). Agreed to by the State of Nevada; U.S. Department of Energy, Environmental Management; U.S. Department of Defense; and U.S. Department of Energy, Legacy Management. Appendix VI, which contains the Underground Test Area Strategy, was last modified May 2011, Revision No. 4.

Mishra, S. 2002. Assigning Probability Distributions to Input Parameters of Performance Assessment Models, TR-02-11. Prepared by INTERA, Inc. Stockholm, Sweden: Swedish Nuclear Fuel and Waste Management Co.

N-I, see Navarro-Intera, LLC.

NNES, see Navarro Nevada Environmental Services, LLC.

NNSA/NSO, see U.S. Department of Energy, National Nuclear Security Administration Nevada Site Office.

NRC, see National Research Council.

NSTec, see National Security Technologies, LLC.

National Security Technologies, LLC. 2008. UGTA Health and Safety Plan, Rev. 2. Las Vegas, NV.

National Research Council. 2007. Models in Environmental Regulatory Decision Making. Prepared by the Committee on Models in the Regulatory Decision Process. Washington, DC: National Academies Press.

Navarro-Intera, LLC. 2010. External Peer Review Team Report Underground Testing Area Subproject for Frenchman Flat, Rev. 1, N-I/28091--021. Las Vegas, NV.

Navarro-Intera, LLC. 2011. Written communication. Subject: "Standards-Based Management System." Las Vegas, NV.

Navarro Nevada Environmental Services, LLC. 2010. Phase II Transport Model of Corrective Action Unit 98: Frenchman Flat, Nevada Test Site, Nye County, Nevada, Rev.1, N-I/28091--004, S-N/99205--122. Las Vegas, NV.

SNJV, see Stoller-Navarro Joint Venture.

Stoller-Navarro Joint Venture. 2004. Transferability of Data Related to the Underground Test Area Project, Nevada Test Site, Nye County, Nevada, Rev. 0, S-N/99205--020. Las Vegas, NV.

U.S. Department of Energy. 2005. Quality Assurance, DOE Order 414.1C. Washington, DC.

U.S. Department of Energy. 2006. Records Management Program, DOE Order 243.1. Washington, DC. 
U.S. Department of Energy. 2007a. Identifying Classified Information, DOE Order 475.2. Washington, DC.

U.S. Department of Energy. 2007b. Manual for Identifying Classified Information, DOE Manual 475.1-1B. Washington, DC.

U.S. Department of Energy. 2008. Information Technology Management, DOE Order 200.1A. Washington, DC.

U.S. Department of Energy. 2010. Scientific and Technical Information Management, DOE Order 241.1B. Washington, DC.

U.S. Department of Energy, National Nuclear Security Administration Nevada Site Office. 2009. Underground Test Area Project Waste Management Plan, Rev. 3, DOE/NV--343; Attachment 1 Fluid Management Plan for the Underground Test Area Project, Rev. 5; DOE/NV--370-Rev.5. Las Vegas, NV.

U.S. Department of Energy, National Nuclear Security Administration Nevada Site Office. 2010. Assessment and Oversight, NSO Order 226.XC. Las Vegas, NV.

U.S. Department of Energy, Nevada Operations Office. 1999. Underground Test Area Project Program Management Plan, Rev. 1, DOE/NV-385. Las Vegas, NV.

U.S. Environmental Protection Agency. 2002. Guidance for Quality Assurance Project Plans for Modeling, EPA QA/G-5M, EPA/240/R-02/007. Washington, DC: Office of Environmental Information.

U.S. Environmental Protection Agency. 2005. Uniform Federal Policy for Quality Assurance Project Plans, EPA-505-B-04-900A. Washington, DC: Intergovernmental Data Quality Task Force.

U.S. Environmental Protection Agency. 2006. Guidance on Systematic Planning Using the Data Quality Objectives Process, EPA QA/G-4, EPA/240/B-06/001. Washington, DC: Office of Environmental Information.

U.S. Environmental Protection Agency. 2009. Guidance on the Development, Evaluation, and Application of Environmental Models, EPA/100/K-09/003. Washington, DC: Office of the Science Advisor.

U.S. Environmental Protection Agency. 2011. SW-846, Test Methods for Evaluating Solid Waste, Physical/Chemical Methods. As accessed at http://www.epa.gov/epawaste/hazard/testmethods/sw846 on 23 March. 
Attachment 1

\section{UGTA Field Measurements}

UNCONTROLLED When Printed 
Table 1-1

\section{UGTA Field Measurements}

(Page 1 of 7 )

\begin{tabular}{|c|c|c|c|c|}
\hline Measurement & \begin{tabular}{|l|} 
Responsible \\
Organization
\end{tabular} & Purpose $^{\mathrm{a}}$ & Procedure & Comments \\
\hline \multicolumn{5}{|c|}{ General Procedures } \\
\hline \multirow{4}{*}{$\begin{array}{l}\text { Monitoring and Documenting } \\
\quad \text { Field Activities }\end{array}$} & $\overline{\mathrm{DRI}}$ & \multirow{4}{*}{$\mathrm{T}, \mathrm{O}$} & SOP.RLFA: Standard Operating Procedure for Recording Laboratory and Field Activities & \multirow{4}{*}{--} \\
\hline & ER & & UF-DR-4: Monitoring and Documenting Well-Site Activities & \\
\hline & LANL & & UGTA-LANL-SOP-1.01: Documenting Scientific Investigations & \\
\hline & $\mathrm{M} \& \mathrm{O}$ & & $\begin{array}{l}\text { NSTec OP-2152.209: Geologic Well-Site Support; } \\
\text { NSTec OP-2152.206: Data Validation and Reporting }\end{array}$ & \\
\hline \multicolumn{5}{|c|}{ Well Drilling and Completion } \\
\hline \multirow{2}{*}{ Drilling Oversight } & $\mathrm{M} \& \mathrm{O}$ & O & $\begin{array}{l}\text { NSTec OP-2152.209: Geologic Well-Site Support; } \\
\text { NSTec OP-2152.206: Data Validation and Reporting; } \\
\text { NSTec FAWP Baker Atlas FY09 to FY13 }\end{array}$ & -- \\
\hline & ER & O & $\begin{array}{c}\text { Field Instruction for the Underground Test Area Project Drilling and Well Completion } \\
\text { Operations, Nevada Test Site, Nevada; ER FAWP }\end{array}$ & -- \\
\hline Drilling and Completion History & M\&O & $\mathrm{T}, \mathrm{O}$ & $\begin{array}{l}\text { NSTec OP-2152.209: Geologic Well-Site Support; } \\
\text { NSTec OP-2152.206: Data Validation and Reporting }\end{array}$ & -- \\
\hline Cementing Record & $\mathrm{M} \& \mathrm{O}$ & $\mathrm{O}$ & \multirow{2}{*}{$\begin{array}{l}\text { NSTec SOW; Work Instructions: Work Package \# COLOG - FY09 to FY13, "Cement, } \\
\text { Gravel-Pack Monitoring/Logging"; Well-Specific FAWPs }\end{array}$} & -- \\
\hline Stemming Record & $\mathrm{M} \& \mathrm{O}$ & $\mathrm{T}, \mathrm{O}$ & & -- \\
\hline Pipe Tally & $\mathrm{M} \& \mathrm{O}$ & 0 & NSTec Well-Specific FAWPs: "Mainhole Drilling and Completion of Well__" & -- \\
\hline \begin{tabular}{|l|} 
Drilling Parameters (Weight on Bit, \\
Pump Pressure, Drill Bit Rotation, \\
Rate of Penetration, Water Production) \\
\end{tabular} & Sub $(M \& O)$ & O & SOW and Drilling Subcontractor SOPs & -- \\
\hline \multicolumn{5}{|c|}{ Well Development and Testing } \\
\hline $\begin{array}{l}\text { Well Development and Testing } \\
\text { Oversight }\end{array}$ & ER & $\mathrm{O}$ & $\begin{array}{l}\text { Field Instruction for UGTA Project Well Development, Hydraulic Testing, and } \\
\text { Groundwater Sampling }\end{array}$ & -- \\
\hline Well Development & ER & $T$ & UF-WDT-2: Well Development & -- \\
\hline Water Production & ER & $\bar{T}$ & UF-EC-3: Flowmeter Operations & -- \\
\hline \multirow{2}{*}{ Pumping Tests } & ER & \multirow{2}{*}{ T } & UF-WDT-1: Step-Drawdown and Constant-Rate Pumping Tests & -- \\
\hline & $\mathrm{M} \& \mathrm{O}$ & & NSTec FAWP/Well- or Task-Specific Work Packages & -- \\
\hline \multirow{2}{*}{ Slug Tests/Packer Injection Tests } & $\overline{E R}$ & \multirow{2}{*}{$\mathrm{T}$} & ER FAWP or Task-Specific Work Packages & $\overline{--}$ \\
\hline & $\mathrm{M} \& \mathrm{O}$ & & NSTec FAWP/Well- or Task-Specific Work Packages & -- \\
\hline
\end{tabular}

\section{UNCONTROLLED When Printed}


Table 1-1

UGTA Field Measurements

(Page 2 of 7 )

\begin{tabular}{|c|c|c|c|c|}
\hline Measurement & \begin{tabular}{|l|} 
Responsible \\
Organization
\end{tabular} & Purpose $^{\mathrm{a}}$ & Procedure & Comments \\
\hline \multicolumn{5}{|c|}{ Borehole Logging } \\
\hline \multirow[t]{2}{*}{ Oversight } & $\mathrm{M} \& \mathrm{O}$ & \multirow[t]{2}{*}{ O } & $\begin{array}{l}\text { NSTec OP-2152.209: Geologic Well-Site Support; } \\
\text { NSTec OP-2152.206: Data Validation and Reporting; Baker Atlas FY09 to FY13; } \\
\text { NSTec FAWP: Wellbore Geophysical Logging and Other Wireline Operations }\end{array}$ & -- \\
\hline & ER & & UF-DR-5: Oversight of Borehole Geophysical Data Acquisition & -- \\
\hline \multirow[b]{2}{*}{ Lithology/Stratigraphy } & $\overline{E R}$ & \multirow[b]{2}{*}{$\mathrm{T}, \mathrm{O}$} & UF-DR-3: Geologic Description of Cuttings and Core & -- \\
\hline & M\&O & & $\begin{array}{c}\text { NSTec OP-2152.203: Rock Description; } \\
\text { NSTec OP-2152.204: Handling and Documenting Geologic Samples }\end{array}$ & -- \\
\hline Conductivity & \multirow{5}{*}{ DRI } & \multirow{5}{*}{ T } & \multirow{5}{*}{$\begin{array}{l}\text { SOP.CT: SOP for Using the Chemistry Logging Tool; } \\
\text { SOP.IDRONAUT: SOP for Using the Idronaut Logging Tool }\end{array}$} & \begin{tabular}{|c|} 
Precision: $0.1 \mu \mathrm{S} / \mathrm{cm}$ (Idronaut) and $10 \%$ (Chemistry Tool) \\
Accuracy: $5 \mu \mathrm{S} / \mathrm{cm}$ (Idronaut) and determined using 3-point \\
calibration (Chemistry Tool)
\end{tabular} \\
\hline Dissolved Oxygen & & & & $\begin{array}{c}\text { Precision: } 0.01 \mathrm{mg} / \mathrm{L} \\
\text { Accuracy: } 0.1 \mathrm{mg} / \mathrm{L} \text { (Idronaut) }\end{array}$ \\
\hline Ion Selective (Bromide) & & & & $\begin{array}{c}\text { Precision: } 1 \mathrm{mg} / \mathrm{L} \\
\text { Accuracy determined using 3-point calibration (Idronaut) }\end{array}$ \\
\hline $\mathrm{pH}$ & & & & \begin{tabular}{|c|} 
Precision: 0.001 (Idronaut) | 0.01 (Chemistry Tool) \\
Accuracy: 0.01 (Idronaut) | 0.02 (Chemistry Tool) pH units
\end{tabular} \\
\hline Temperature & & & & $\begin{array}{l}\text { Precision: } 0.001 \text { (Idronaut) | } 0.01 \text { (Chemistry Tool) }{ }^{\circ} \mathrm{C} \\
\text { Accuracy: } 0.005 \text { (Idronaut) | } 0.05 \text { (Chemistry Tool) }{ }^{\circ} \mathrm{C}\end{array}$ \\
\hline Flow Logging & DRI & $\mathrm{T}$ & SOP.TFM: SOP for Using Thermal Flowmeter & $\begin{array}{c}\text { Precision: } 0.1 \mathrm{gpm} \\
\text { Accuracy checked with 5-point calibration } \\
\text { in laboratory flow tank (annually and after repairs); } \\
\text { checked before use during field operation }\end{array}$ \\
\hline $\begin{array}{c}\text { Geophysical Logging } \\
\text { (Caliper, Sonic, Gamma Ray, Spectral } \\
\text { Gamma Ray, Resistivity, Density, } \\
\text { Neutron, Image, Sidewall Coring - } \\
\text { Rotary and Percussion Gun) }\end{array}$ & Sub (M\&O) & $\mathrm{T}, \mathrm{O}$ & SOW and Logging Subcontractor Procedures & -- \\
\hline Video & USGS & $\mathrm{T}, \mathrm{O}$ & USGS NWSC: Procedure for Well Video Logging for the USDOE, NNSA & $\begin{array}{l}\text { Accuracy of depth counter of winch } \\
\text { is }+/-0.2 \% \text { of total depth }\end{array}$ \\
\hline
\end{tabular}


Table 1-1

\section{UGTA Field Measurements}

(Page 3 of 7)

\begin{tabular}{|c|c|c|c|c|}
\hline Measurement & \begin{tabular}{|l|} 
Responsible \\
Organization
\end{tabular} & Purpose $^{\mathrm{a}}$ & Procedure & Comments \\
\hline \multicolumn{5}{|c|}{ Water-Level Measurements } \\
\hline \multirow{3}{*}{ Water-Level Measurements (Wireline) } & ER & \multirow{3}{*}{$\mathrm{T}, \mathrm{O}$} & UF-FMM-1: Depth-to-Water Measurements & $\begin{array}{l}\text { Accuracy of reference steel-tape } 1.000 \pm 0.015(\mathrm{RE}) ; \\
\text { not used for precision measurements (not calibrated) }\end{array}$ \\
\hline & DRI & & SOP.GWL: SOP for Determining Groundwater Levels & $\begin{array}{c}\text { Precision is } 0.1 \mathrm{ft} \text { per } 1,000 \mathrm{ft} \text {; wireline length calibrated } \\
\text { periodically in an existing well with known depth. } \\
\text { Calibrated at least within } 1 \text { year of making measurements. }\end{array}$ \\
\hline & USGS & & $\begin{array}{l}\text { USGS NWSC: Procedure for Manually Measuring Depth-to-Water with Steel Tapes, } \\
\text { Electric Tapes, and Wirelines for the USDOE, NNSA }\end{array}$ & Precision is $+/-0.50 \mathrm{ft}$. \\
\hline \multirow{2}{*}{$\begin{array}{l}\text { Water-Level Measurements } \\
\text { (Steel Tapes/Electric Tapes) }\end{array}$} & ER & \multirow{2}{*}{$\mathrm{T}, \mathrm{O}$} & $\begin{array}{l}\text { UF-EC-1: Calibration of Water-Level Measurement Equipment } \\
\text { UF-FMM-1: Depth-to-Water Measurements }\end{array}$ & -- \\
\hline & USGS & & $\begin{array}{c}\text { Procedure for Manually Measuring Depth-to-Water with Steel Tapes, } \\
\text { Electric Tapes, and Wirelines for the USDOE, NNSA }\end{array}$ & $\begin{array}{l}\text { Precision: Steel tapes } 0.02 \mathrm{ft}(<200 \mathrm{ft}), 1 / 10,000(>200 \mathrm{ft}) \\
\text { Electric tapes } 0.10 \mathrm{ft}(<1,000 \mathrm{ft}), 1 / 10,000(>1,000 \mathrm{ft})\end{array}$ \\
\hline \multirow[b]{2}{*}{$\begin{array}{l}\text { Water-Level Measurements } \\
\quad \text { (Continuous) }\end{array}$} & ER & \multirow[b]{2}{*}{$\mathrm{T}$} & UF-WDT-2: Well Development; UF-EC-2: Datalogger Operations & -- \\
\hline & USGS & & $\begin{array}{l}\text { USGS NWSC: Procedure for Transducer Installation in a Well for the USDOE, NNSA; } \\
\text { Procedure for Data Logger Maintenance for the USDOE, NNSA }\end{array}$ & $\begin{array}{l}\text { Transducers are calibrated at the time of installation and } \\
\text { removal. The correlation coefficient of a linear regression of } \\
\text { the calibration data is used to evaluate precision. } \\
\text { Acceptable correlation coefficients range from } 0.98 \text { to } 1.02 \text {. } \\
\text { If possible, the transducer precision is evaluated between } \\
\text { installation and removal by comparing instantaneous } \\
\text { transducer pressure readings with fairly simultaneous } \\
\text { water-level measurements. Manufacturer reports } \\
\text { transducer accuracy is } 0.02 \% \text { of full scale output. }\end{array}$ \\
\hline Well Depth & USGS & $\mathrm{T}$ & USGS NWSC: Procedure for Sounding Wells for the USDOE, NNSA & $\begin{array}{l}\text { Wirelines are used to sound deep wells; } \\
\text { repeatable precision is estimated to be }+/-1 \text { to } 3 \mathrm{ft} \text {. }\end{array}$ \\
\hline
\end{tabular}


Table 1-1

UGTA Field Measurements

Page 1-4 of 1-7

(Page 4 of 7 )

\begin{tabular}{|c|c|c|c|c|}
\hline Measurement & \begin{tabular}{|l|} 
Responsible \\
Organization
\end{tabular} & Purpose $e^{a}$ & Procedure & Comments \\
\hline \multicolumn{5}{|c|}{ Sample Collection } \\
\hline \multirow{3}{*}{ Water Chemistry } & ER & $\mathrm{T}, \mathrm{R}, \mathrm{O}$ & $\begin{array}{l}\text { Field Instruction for UGTA Project Well Development, Hydraulic Testing, and } \\
\text { Groundwater Sampling; UF-SC-1: Collecting DOC Isotope Samples for DRI Analysis; } \\
\text { UF-SC-2: Collecting } \delta^{2} \mathrm{H}, \delta^{18} \mathrm{O} \text {, and } \delta^{13} \mathrm{C} \text { Groundwater Samples for DRI Analysis; } \\
\text { UF-SC-3: Collecting } 55 \text {-Gallon Drum Samples for LANL Analysis; } \\
\text { UF-SC-4: Collecting Groundwater Samples for LLNL Analysis; } \\
\text { UF-SC-5: Collecting Trace Level Aluminum and Iron Groundwater Samples } \\
\text { for DRI Analysis; UF-SC-6: Collecting }{ }^{234 / 238}{ }^{87786} \mathrm{Sr} \text {, and }{ }^{32 / 34} \text { S Groundwater Samples } \\
\text { for USGS Analysis; UF-SC-8: Fluid Sample Collection, Field Filtration, and Processing }\end{array}$ & -- \\
\hline & DRI & $\mathrm{T}, \mathrm{R}, \mathrm{O}$ & $\begin{array}{c}\text { SOP.WPGS: SOP for Well-Purging and Collecting Groundwater Samples; } \\
\text { SOP.SCGW: SOP for Shipping and Control of Groundwater Samples; } \\
\text { SOP.DOC: SOP for Collecting DOC Isotope Samples; } \\
\text { SOP.ISOTOPES: SOP for Collecting } \delta^{2} \mathrm{H}, \delta^{18} \mathrm{O}, \delta^{13} \mathrm{C} \text {, and }{ }^{3} \mathrm{H} \text { Groundwater Samples; } \\
\text { SOP.AL\&Fe: SOP for Collecting Trace-Level Aluminum and Iron Groundwater Samples }\end{array}$ & -- \\
\hline & LLNL & $\mathrm{T}, \mathrm{R}, \mathrm{O}$ & $\begin{array}{l}\text { SOP-UGTA-109: Management of Samples and Records; } \\
\text { SOP-UGTA-124: Procedure for Collecting Samples from Wells at the Nevada Test Site; } \\
\text { LLNL ANCD-01: Procedure for Decontamination of Down-Hole Equipment; } \\
\text { LLNL ANCD-02: Procedure for Collecting Groundwater Samples via Submersible Pump } \\
\text { or Discrete Interval Sampler (Bailer); LLNL ANCD-03: Sample Handling Procedure; } \\
\text { LLNL ANCD-04: Routine LSC Procedure for Providing Preliminary Field-Scan }{ }^{3} \mathrm{H} \text { Activity } \\
\text { Data; LLNL ANCD-05: Operation and Maintenance of Field Measurement Equipment }\end{array}$ & -- \\
\hline \multirow{2}{*}{$\begin{array}{c}\text { Cuttings } \\
\text { (Sample Handling and Analysis) }\end{array}$} & ER & \multirow{2}{*}{ T } & $\begin{array}{l}\text { UF-SC-7: Cuttings Sample Collection, Handling, and Oversight; } \\
\text { UF-DR-3: Geologic Description of Cuttings and Core }\end{array}$ & -- \\
\hline & $\mathrm{M} \& \mathrm{O}$ & & NSTec OP-2152.204: Handling and Documenting Geologic Samples & -- \\
\hline \multirow{3}{*}{$\begin{array}{c}\text { Core } \\
\text { (Sample Handling and Analysis) }\end{array}$} & ER & \multirow{3}{*}{$\mathrm{T}$} & $\begin{array}{l}\text { UF-SC-9: Oversight of Core Handling and Sampling; } \\
\text { UF-DR-3: Geologic Description of Cuttings and Core }\end{array}$ & -- \\
\hline & $\mathrm{M} \& \mathrm{O}$ & & NSTec OP-2152.204: Handling and Documenting Geologic Samples & -- \\
\hline & Sub (M\&O) & & BHI Procedure: CRGH-Well (Percussion type core samples) & -- \\
\hline \multirow[b]{2}{*}{$\begin{array}{l}\text { Sidewall Core } \\
\text { (Sample Handling and Analysis) }\end{array}$} & ER & \multirow[b]{2}{*}{$\mathrm{T}, \mathrm{O}$} & UF-DR-3: Geologic Description of Cuttings and Core & -- \\
\hline & $\mathrm{M} \& \mathrm{O}$ & & $\begin{array}{c}\text { NSTec OP-2152.209: Geologic Well-Site Support; } \\
\text { NSTec OP-2152.206: Data Validation and Reporting; } \\
\text { NSTec OP-2152.203: Rock Description; } \\
\text { NSTec OP-2152.204: Handling and Documenting Geologic Samples }\end{array}$ & -- \\
\hline
\end{tabular}


Table 1-1

UGTA Field Measurements

(Page 5 of 7)

\begin{tabular}{|c|c|c|c|c|}
\hline Measurement & \begin{tabular}{|l|} 
Responsible \\
Organization
\end{tabular} & Purpose $^{\mathrm{a}}$ & Procedure & Comments \\
\hline \multicolumn{5}{|c|}{ Sample Collection (continued) } \\
\hline Surface Geologic Sampling & \multirow{3}{*}{ ER } & $\bar{T}$ & UF-SC-10: Surface Geologic Sampling & -- \\
\hline Decontamination & & $\mathrm{O}$ & UF-EC-4: Small Equipment Decontamination & -- \\
\hline Drilling Fluid & & $\mathrm{R}$ & UF-SC-8: Fluid Sample Collection, Field Filtration, and Processing & -- \\
\hline \multicolumn{5}{|c|}{ Water-Quality and Miscellaneous Measurements } \\
\hline \multirow[b]{2}{*}{ Alkalinity } & $\overline{\mathrm{ER}}$ & $\bar{T}$ & UF-FMM-3: Measuring Alkalinity in the Field & $-\overline{-}$ \\
\hline & DRI & $\mathrm{T}$ & SOP.FMA: SOP for Measuring Alkalinity in the Field & $\begin{array}{l}\text { Accuracy for } \mathrm{pH} \text { meter is } 0.02 \mathrm{pH} \text { units. Digital titrator is } \\
\text { calibrated in factory new. No further calibrations conducted. } \\
\text { Manufacturer reports that reproducibility should be } \pm 5 \% \text {. }\end{array}$ \\
\hline $\begin{array}{l}\text { Bromide, Dissolved Oxygen, pH, } \\
\text { Specific Conductance, Temperature, } \\
\text { Turbidity (Discrete Samples) }\end{array}$ & \multirow[t]{2}{*}{ ER } & $\mathrm{T}$ & UF-FMM-4: Water Quality Monitoring & $\begin{array}{c}\text { For bromide: } \pm 10 \% \text { (QCCS). } \\
\text { Calibrate before analysis, and check at the end of the day. } \\
\text { Accuracy is } \pm 2^{\circ} \mathrm{C} \text { (Certified thermometer). } \\
\text { Also measured in lab. }\end{array}$ \\
\hline $\begin{array}{c}\text { Dissolved Oxygen, pH, Specific } \\
\text { Conductance, Temperature, Turbidity } \\
\text { (In-line Monitoring) }\end{array}$ & & $\mathrm{T}$ & $\begin{array}{l}\text { UF-FMM-4: Water Quality Monitoring; } \\
\text { UF-EC-2: Datalogger Operations }\end{array}$ & $\begin{array}{l}\text { Calibrated at the beginning of the activity, } \\
\text { and checked at the end of the activity. }\end{array}$ \\
\hline Bromide & \multirow{4}{*}{ DRI } & \multirow[t]{2}{*}{$\mathrm{T}, \mathrm{O}$} & SOP.FBM: SOP for Measuring Bromide in the Field & $\begin{array}{c}\text { Field screening for well development and groundwater } \\
\text { sampling. Similar values over several sampling periods } \\
\text { during pumping indicates (along with other parameters) } \\
\text { that the well is developed or the well has been properly } \\
\text { purged before sampling. Precision is } 2 \% ; \\
\text { accuracy determined using } 6 \text {-point calibration. }\end{array}$ \\
\hline Dissolved Oxygen & & & SOP.DO: SOP for Calibrating and Using Portable Dissolved Oxygen Meters & $\begin{array}{l}\text { Precision is } 0.01 \mathrm{mg} / \mathrm{L} \text {, and accuracy is } \pm 0.3 \mathrm{mg} / \mathrm{L} \text {; } \\
\text { one-point calibration at } 100 \% \text { saturation. }\end{array}$ \\
\hline $\mathrm{pH}$ & & $\mathrm{T}$ & SOP.PH: SOP for Calibrating and Using Portable $\mathrm{pH}$ and Temperature Meters & $\begin{array}{c}\text { Precision is } 0.01 \mathrm{pH} \text { units, and accuracy is } \pm 0.02 \mathrm{pH} \text { units } \\
\text { (3 buffer calibrations: } \mathrm{pH} 4, \mathrm{pH} 7 \text {, and } \mathrm{pH} 10) \text {. }\end{array}$ \\
\hline Specific Conductance & & T, O & $\begin{array}{l}\text { SOP.EC: SOP for Calibrating and Using Portable Electrical Conductivity Meters } \\
\text { in the Field }\end{array}$ & $\begin{array}{l}\text { Precision is } 10 \% \text {; } 3 \text { standards: } 100,500, \text { and } 1,000 \mu \mathrm{S} \text {. } \\
\text { The two standards that bracket the measurement are used } \\
\text { for the post-measurement manual calibration. }\end{array}$ \\
\hline
\end{tabular}


Table 1-1

UGTA Field Measurements

(Page 6 of 7)

\begin{tabular}{|c|c|c|c|c|}
\hline Measurement & \begin{tabular}{|l|} 
Responsible \\
Organization
\end{tabular} & Purpose ${ }^{a}$ & Procedure & Comments \\
\hline \multicolumn{5}{|c|}{ Water-Quality and Miscellaneous Measurements (continued) } \\
\hline Temperature & \multirow[b]{2}{*}{ DRI } & $\mathrm{T}, \mathrm{O}$ & SOP.PH: SOP for Calibrating and Using Portable $\mathrm{pH}$ and Temperature Meters & $\begin{array}{l}\text { Precision is } 0.1^{\circ} \mathrm{C} \text { and accuracy is } \pm 1.0^{\circ} \mathrm{C} \text {; only original } \\
\text { factory calibration for temperature probe. Main purpose of } \\
\text { this measurement is for temperature compensation of } \mathrm{pH} \text {. }\end{array}$ \\
\hline Turbidity & & O & SOP.TURB: SOP for Measuring Turbidity in the Field & $\begin{array}{l}\text { Precision is } 0.02 \mathrm{NTU} \text {; field screening for well development } \\
\text { and groundwater sampling. Similar values over several } \\
\text { sampling periods during pumping indicates (along with } \\
\text { other parameters) that the well is developed or the well has } \\
\text { been properly purged before sampling. }\end{array}$ \\
\hline Flow Rates & USGS & $\mathrm{T}$ & $\begin{array}{l}\text { USGS NWSC Procedure for Flow Rate Measurements for the USDOE, NNSA; } \\
\text { Procedure for Data Logger Maintenance for the USDOE, NNSA }\end{array}$ & Accuracy checked by field comparison $(+/-10 \%)$. \\
\hline $\begin{array}{c}\text { Temperature } \\
\text { (In-line Monitoring) }\end{array}$ & USGS & $\mathrm{T}, \mathrm{O}$ & $\begin{array}{l}\text { USGS NWSC: Procedure for Collecting Ground-Water Temperature Data } \\
\text { for the USDOE, NNSA }\end{array}$ & Accuracy is $+/-1.0^{\circ} \mathrm{C}$. \\
\hline \multirow{2}{*}{$\begin{array}{l}\text { Weather Conditions/ } \\
\text { Barometric Pressure }\end{array}$} & $\overline{E R}$ & $\mathrm{O}$ & UF-DR-4: Monitoring and Documenting Well-Site Activities & -- \\
\hline & $\mathrm{M} \& \mathrm{O}$ & $\mathrm{O}$ & UGTA Project Health \& Safety Plan; FAWPs & -- \\
\hline \multicolumn{5}{|c|}{ Surface Measurements } \\
\hline \multirow{2}{*}{$\begin{array}{c}\text { Geophysics } \\
\text { (Seismic, Resistivity, Gravity Survey) }\end{array}$} & $\overline{\mathrm{M} \& \mathrm{O}}$ & & NSTec OP-2152.208: General Field Instructions for Geotechnical Activities & $\overline{--}$ \\
\hline & Sub (M\&O) & $\mathrm{T}$ & SOW and subcontractor procedures & -- \\
\hline Magnetic Survey & \multirow[b]{2}{*}{ USGS } & $\bar{T}$ & USGS NWSC Procedure for Magnetotelluric Data Collection for the USDOE, NNSA & -- \\
\hline Gravity Survey & & $\mathrm{T}$ & $\begin{array}{l}\text { USGS NWSC Procedure for Ground-Based Magnetic Data Collection } \\
\text { for the USDOE, NNSA }\end{array}$ & -- \\
\hline \multirow[b]{2}{*}{ Surface Mapping } & $\mathrm{M \& O}$ & \multirow[b]{2}{*}{$\mathrm{T}$} & NSTec OP-2152.202: Geologic Mapping & -- \\
\hline & USGS & & $\begin{array}{l}\text { USGS NWSC Procedure for Tripod LiDAR Data Collection } \\
\text { for the USDOE, NNSA }\end{array}$ & -- \\
\hline \multirow{3}{*}{ Well Location Survey } & $\overline{E R}$ & \multirow{3}{*}{$\mathrm{T}$} & UF-DR-1: Acquisition and Use of Well Surveying and Marking Data & -- \\
\hline & $\mathrm{M} \& \mathrm{O}$ & & $\begin{array}{l}\text { NSTec General Operating Procedures for Land Surveying } \\
\text { (OP-2110.308, OP-2110.309, OP-2110.310) }\end{array}$ & $\begin{array}{l}\text { Accuracy of as-built locations to }+/-0.1 \mathrm{ft} ; \\
\text { dirt work to }+/-0.5 \mathrm{ft}\end{array}$ \\
\hline & USGS & & USGS NWSC Procedure for Global Positioning System Surveys for the USDOE, NNSA & \begin{tabular}{|l|} 
Depending on equipment and type of survey, horizontal and \\
vertical datum can range from 1 to $6 \mathrm{~cm}$ in accuracy.
\end{tabular} \\
\hline
\end{tabular}

\section{UNCONTROLLED When Printed}


Table 1-1

UGTA Field Measurements

(Page 7 of 7 )

\begin{tabular}{|c|c|c|c|c|}
\hline Measurement & \begin{tabular}{|l|} 
Responsible \\
Organization
\end{tabular} & Purpose $^{\mathrm{a}}$ & Procedure & Comments \\
\hline \multicolumn{5}{|c|}{ Regulatory Measurements } \\
\hline \multirow[t]{2}{*}{ Sump Fluid Monitoring } & \multirow[t]{2}{*}{ ER } & $\mathrm{R}, \mathrm{O}$ & $\begin{array}{l}\text { UF-DR-2: Fluid Management Status Reporting for Wells in Progress; } \\
\text { UF-SC-8: Fluid Sample Collection, Field Filtration, and Processing }\end{array}$ & -- \\
\hline & & $\mathrm{R}, \mathrm{O}$ & UF-EC-4: Small Equipment Decontamination & -- \\
\hline \multirow{2}{*}{ Tritium Monitoring } & ER & $\mathrm{T}, \mathrm{R}, \mathrm{O}$ & \begin{tabular}{|l|} 
UF-FMM-6: DRAFT Tritium Monitoring; UF-SC-8: Fluid Sample Collection, Field \\
Filtration, and Processing; Fluid Management Plan for the Underground Test Area Project
\end{tabular} & \multirow{2}{*}{$\begin{array}{c}\text { Field screening for potential }{ }^{3} \mathrm{H} \text { contamination of } \\
\text { groundwater. If the field analysis is above } 20,000 \mathrm{pCi} / \mathrm{L} \text {, } \\
\text { a sample is collected and sent for laboratory analysis. } \\
\text { Precision is } 1,000 \mathrm{pCi} / \mathrm{L} \text {. }\end{array}$} \\
\hline & DRI & 0 & SOP.MT: SOP for Measuring ${ }^{3} \mathrm{H}$ in the Field & \\
\hline $\begin{array}{l}\text { Radiological Release Surveys for } \\
\text { Equipment and Materials }\end{array}$ & $\mathrm{M} \& O$ & $\mathrm{R}, \mathrm{O}$ & NSTec CD-0441.004 (Rev. 1): Material Release Program & -- \\
\hline $\begin{array}{l}\text { Field Screening for Lead in } \\
\text { Fluid Samples }\end{array}$ & ER & $\mathrm{R}$ & $\begin{array}{l}\text { UF-FMM-2: Field Screening for Lead in Fluid Samples; } \\
\text { UF-SC-8: Fluid Sample Collection, Field Filtration, and Processing; } \\
\text { Fluid Management Plan for the Underground Test Area Project }\end{array}$ & $\begin{array}{l}\text { Precision is measured by duplicates. } \\
\text { Matrix spikes used to determine accuracy. }\end{array}$ \\
\hline
\end{tabular}

a Purpose: $\mathrm{O}=$ Operational, $\mathrm{R}=$ Regulatory, $\mathrm{T}=$ Technical/Scientific

$--=$ Not applicable

$\mathrm{BHI}=$ Baker Hughes, Inc.

${ }^{\circ} \mathrm{C}=$ Degrees Celsius

$\mathrm{cm}=$ Centimeter

COLOG = Colog, Inc.

$\mathrm{ft}=$ Foot

$\mathrm{FY}=$ Fiscal year

gpm $=$ Gallons per meter

LiDAR = Light detection and ranging

LSC = Liquid scintillation counting

$\mathrm{mg} / \mathrm{L}=$ Milligrams per liter

NSTec $=$ National Security Technologies, LLC

NTU = Nephelometric turbidity unit

NWSC = Nevada Water Science Center

$\mathrm{pCi} / \mathrm{L}=$ Picocuries per liter

QCCS = Quality control check standard

$\mathrm{RE}=$ Relative error

$\mu \mathrm{S} / \mathrm{cm}=$ Microsiemens per centimeter

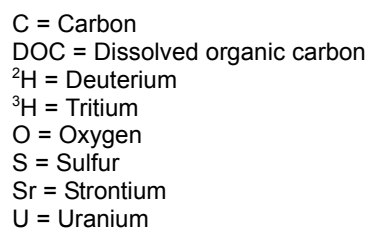

FC-8: Fluid Sample Collection, Field Filtration, and Processing;

Matrix spikes used to determine accuracy.

(n) 
Attachment 2

\section{Laboratory Analyses, Parameters, Methods, and Requirements}


Table 2-1

Groundwater Characterization Parameters

(Page 1 of 3 )

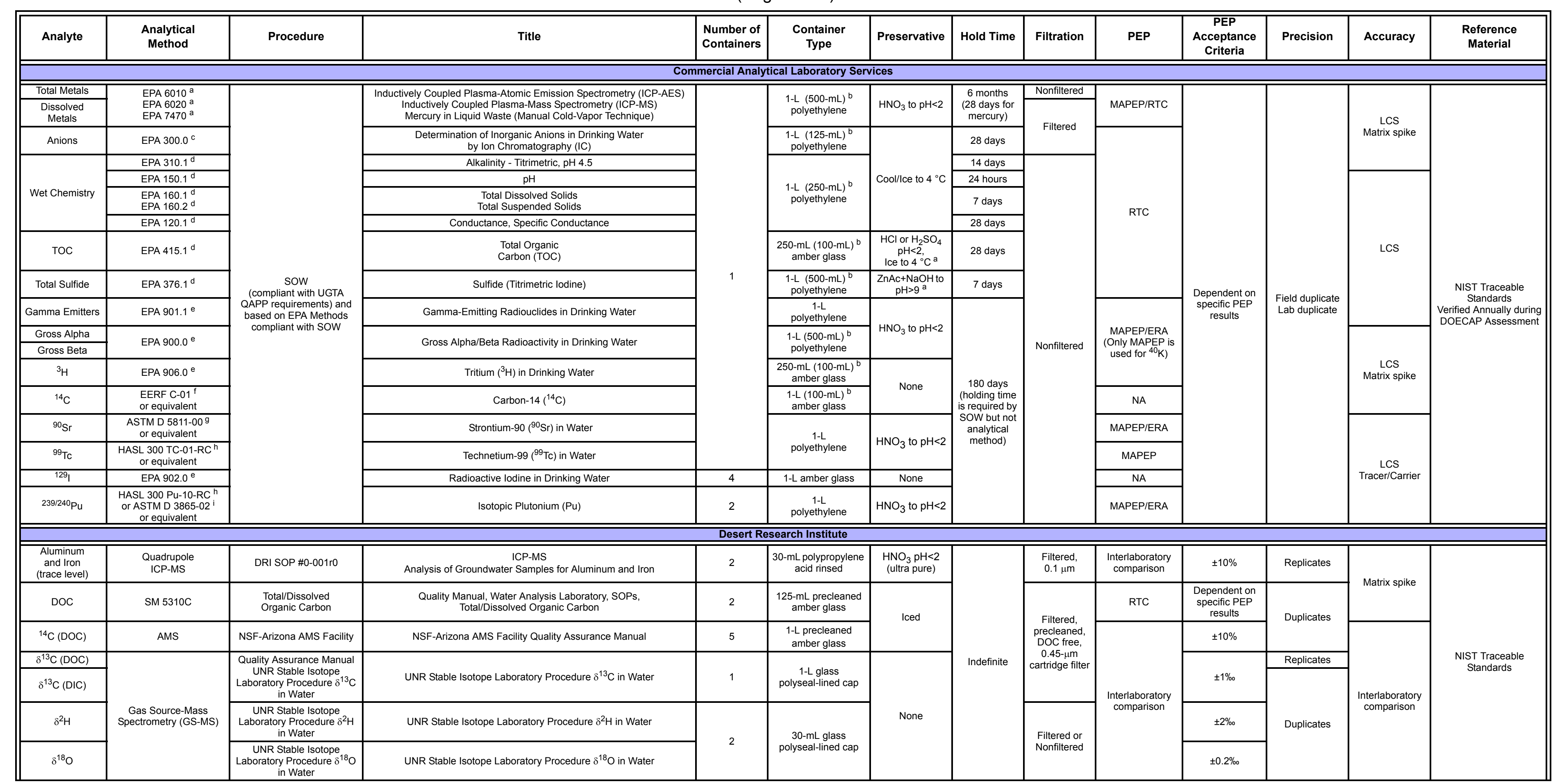


Table 2-1

Groundwater Characterization Parameters

(Page 2 of 3 )

\begin{tabular}{|c|c|c|c|c|c|c|c|c|c|c|c|c|c|}
\hline Analyte & $\begin{array}{l}\text { Analytical } \\
\text { Method }\end{array}$ & Procedure & Title & $\begin{array}{l}\text { Number of } \\
\text { Containers }\end{array}$ & $\begin{array}{c}\text { Container } \\
\text { Type }\end{array}$ & Preservative & Hold Time & Filtration & PEP & \begin{tabular}{|c|} 
PEP \\
Acceptance \\
Criteria
\end{tabular} & Precision & Accuracy & $\begin{array}{c}\text { Reference } \\
\text { Material }\end{array}$ \\
\hline \multicolumn{14}{|c|}{$\begin{array}{l}\text { Lawrence Livermore National Laboratory } \\
\text { L L }\end{array}$} \\
\hline \begin{tabular}{|c|c|c|} 
Major Cations/ \\
reace \\
Elements
\end{tabular} & ICP-MS & $\begin{array}{l}\text { SOP-UGTA-133 } \\
\text { SOP-UGTA-134 }\end{array}$ & $\begin{array}{l}\text { IlP-MS Sample Preparation, } \\
\text { Sample Analysis by Quadrupole ICP-MS }\end{array}$ & \multirow{14}{*}{1} & 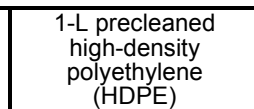 & $\begin{array}{l}\mathrm{HNO}_{3} \text { to pH } 2,2, \\
\text { Coolice to } 4.2 \mathrm{C}\end{array}$ & 6 months & \multirow{2}{*}{$\begin{array}{c} \\
\text { Filtered } \\
(0.45-\mu m)\end{array}$} & \multirow[t]{2}{*}{\begin{tabular}{c|c} 
MAPEP/ \\
Interlaboratory \\
comparison (ILC)
\end{tabular}} & \multirow{2}{*}{\begin{tabular}{|c|c|}
$\begin{array}{c}\text { Dependent on } \\
\text { specific PEP } \\
\text { results }\end{array}$ \\
$\begin{array}{c} \pm 25 \% \\
(>10 \text { times MDL } \\
\text { No linitation } \\
(<10 \text { times MDL }\end{array}$ \\
\end{tabular}} & & $\begin{array}{c}\text { Matrix spike, } \\
\text { LCS }\end{array}$ & $\begin{array}{l}\text { NIST 1640, } \\
\text { NIST 1643e, SLRS4 }\end{array}$ \\
\hline Inorganic Anions & $\left(\begin{array}{c}1 C \\
\text { IC } 300.0)\end{array}\right.$ & SOP-UGTA-120 & Determination of Inorganic Anions by IC & & $\begin{array}{c}\text { 120-mL } \\
\text { 1-CHEM } \\
\text { precleaned } \\
\text { HDPE }\end{array}$ & Cool/lice to $4^{\circ} \mathrm{C}$ & 28 days & & & & & \multirow{15}{*}{$\left|\begin{array}{l}\text { Interlaboratory } \\
\text { comperisisn and } \\
\text { NIST Standards }\end{array}\right|$} & $\begin{array}{l}\text { Spex Certiprep IC } \\
\text { Instrument Check } \\
\text { Standard } 6\end{array}$ \\
\hline \begin{tabular}{|l}
$\begin{array}{l}\text { Total Dissolved } \\
\text { Inorganic } \\
\text { Carbon (TDIC) }\end{array}$ \\
\end{tabular} & \multirow{2}{*}{$\begin{array}{l}\text { Automated TDIC/TDOC } \\
\text { extraction system }\end{array}$} & \multirow{4}{*}{ SOP-UGTA-116 } & \multirow{4}{*}{$\begin{array}{l}\text { Analysis of TDIC/TDOC Concentrations and Isotopes } \\
\text { in Groundwater Samples }\end{array}$} & & \multirow{3}{*}{ 40-mL amber glass } & \multirow{4}{*}{$\begin{array}{ll}\mathrm{H} \mathrm{HCl}_{2} & \\
\text { Cool/lice to } 4^{\circ} \mathrm{C}\end{array}$} & \multirow{3}{*}{ Indefinite } & \multirow{6}{*}{ Nonfittered } & \multirow{7}{*}{$\begin{array}{l}\text { Interlaboratory } \\
\text { comparison }\end{array}$} & \multirow{2}{*}{ TBD } & \multirow{15}{*}{ Duplicates } & & NIST RM 8544 \\
\hline $\begin{array}{c}\text { Total Dissolved } \\
\text { Organic Carbon } \\
\text { (TDOC) }\end{array}$ & & & & & & & & & & & & & NIST RM 85442 \\
\hline $\begin{array}{l}\delta^{13} C \\
\text { (DIC) }\end{array}$ & $\begin{array}{l}\text { Automated DTIIITIDOC } \\
\text { extraction system, } \\
\text { sototope Ratio Mass } \\
\text { Spectrometry (IRMS) } \\
\end{array}$ & & & & & & & & & $\pm 1 \%$ & & & NIST RM 8544 \\
\hline $\begin{array}{l}{ }^{14} \mathrm{C} \\
(\mathrm{DIC})\end{array}$ & $\begin{array}{l}\text { Vacum extraction, } \\
\text { Accelerator Mass } \\
\text { Spectrometry (AMS) }\end{array}$ & & & & 125-mL amber glass & & \multirow[t]{2}{*}{180 days } & & & \multirow{3}{*}{ TBD } & & & NIST SRM 4990c \\
\hline${ }^{129}$ & \multirow{2}{*}{$\begin{array}{l}\mathrm{AgNO}_{3} \text { extraction, } \\
\text { AMS }\end{array}$} & SOP-UGTA-123 & Analysis of ${ }^{129}$ in Aqueous Samples & & \begin{tabular}{|l|l|l}
$40-\mathrm{mL}$ amber glass \\
\end{tabular} & Cool/lice to $4^{\circ} \mathrm{C}$ & & & & & & & NIST-3230 I and II \\
\hline${ }^{36} \mathrm{Cl}$ & & SOP-UGTA-115 & Analysis of ${ }^{6 \mathrm{C}} \mathrm{C}$ in Aqueous Samples & & \multirow{5}{*}{$\begin{array}{l}\text { 1-LI-CHEM pre- } \\
\text { cleaned } \\
\text { HDPE }\end{array}$} & None & \multirow{6}{*}{ Indefinite } & & & & & & \begin{tabular}{|l|l|} 
University of Berkeley \\
36 CI standard
\end{tabular} \\
\hline $8786 \mathrm{Sr}$ & \multirow{4}{*}{$\begin{array}{c}\text { Plasma lonization } \\
\text { Mutticollector Mass } \\
\text { Spectrometry (PIMMS) }\end{array}$} & SOP-UGTA-117 & ${ }^{87 \mathrm{Sr}}{ }^{86} \mathrm{Sr}$ Analysis of Groundwater Samples & & & \multirow[b]{2}{*}{$\mathrm{HNO}_{3}$ to $\mathrm{pH}<2$} & & \multirow[b]{2}{*}{$\begin{array}{c}\text { Fititerd } \\
(0.45-\mu m)\end{array}$} & & \pm 0.0005 & & & NIST SRM 987 \\
\hline $\begin{array}{l}233 \mathrm{U}, 234 \mathrm{U}, \\
236, \mathrm{U}, 238 \mathrm{U} \\
\end{array}$ & & $\begin{array}{l}\text { SOP-UGTA-130 } \\
\text { SOP-UGTA-118 }\end{array}$ & $\begin{array}{l}\text { Sample Preparation and Analysis of Th, } \mathrm{Np} \text {, Pu and U Isotopes, } \\
{ }_{234} \mathrm{U} / 238 \mathrm{U} \text { Analysis of Groundwater Samples }\end{array}$ & & & & & & IAEA & \begin{tabular}{|c|c|}
$\begin{array}{l}\text { Dependient on } \\
\text { specific PPP } \\
\text { results }\end{array}$ \\
\end{tabular} & & & \multirow{2}{*}{$\begin{array}{l}\text { NIST SRM 4321C } \\
\text { NIST U10 } \\
\text { NIST U005 } \\
\text { NIT U }\end{array}$} \\
\hline$\frac{{ }^{232} \mathrm{Th}}{{ }^{237} \mathrm{~Np}}$ & & SOP-UGTA-130 & Sample Preparation and Analysis of $\mathrm{Th}, \mathrm{Np}, \mathrm{Pu}$ and $\mathrm{U}$ Isotopes & & & \multirow{6}{*}{ None } & & \multirow{6}{*}{ Nonfiltered } & $\begin{array}{c}\text { Interlaboratory } \\
\text { comparison } \\
\end{array}$ & TBD & & & \\
\hline 238/239/240 $\mathrm{Pu}$ & & $\begin{array}{l}\text { SOP-UGTA-130 } \\
\text { SOP-UGTA-135 }\end{array}$ & $\begin{array}{l}\text { Sample Preparation and Analysis of } \mathrm{Th}, \mathrm{Np} \text {, Pu and } \mathrm{U} \text { Isotoopes, } \\
\text { Purification of Plutonium mrom Groundwater Samples for Analysis } \\
\text { by MC-ICP-MS }\end{array}$ & & & & & & IAEA & \begin{tabular}{|l} 
Dependent on \\
specific PEP \\
results
\end{tabular} & & & $\begin{array}{l}\text { NBL CRM } 137 \\
\text { NBL CRM } 138\end{array}$ \\
\hline$\frac{\delta^{2} H}{\delta^{18} \mathrm{O}}$ & $\begin{array}{l}\text { Stable Isotope Mass } \\
\text { Spectrometry } \\
\text { (SI-MS) }\end{array}$ & SOP-UGTA-128 & Analysis of ${ }^{18} \mathrm{O}$ and ${ }^{2} \mathrm{H}$ in Groundwater Samples & & $\begin{array}{l}\text { 30-mL glass polyseal } \\
\text { lined cap }\end{array}$ & & & & \multirow{2}{*}{$\begin{array}{l}\text { Interlaboratory } \\
\text { comparison }\end{array}$} & $\begin{array}{c} \pm 2 \% 0 \\
0.2 \% 0\end{array}$ & & & $\begin{array}{l}\text { NIST RM } 8535 \\
\text { NIST RM } 8536 \\
\text { NIST RM } 8537\end{array}$ \\
\hline $9{ }^{99} \mathrm{Tc}$ & $\begin{array}{l}\text { DOE Method } \\
\text { Compendium } \\
\text { RP-550 (1993) }\end{array}$ & SOP-UGTA-111 & Analysis of ${ }^{9} \mathrm{~T} \mathrm{~T}$ in Aqueous Samples & & $\begin{array}{l}\text { 4-LI-CHEM } \\
\text { precleaned HDPE }\end{array}$ & & 180 days & & & \multirow{3}{*}{ TBD } & & & \begin{tabular}{|l} 
NIST \#4288 (LSC) \\
NIST \#4410H (ICP-MS)
\end{tabular} \\
\hline \begin{tabular}{|c|} 
Noble Gases \\
${ }^{3}$ H Low Level)
\end{tabular} & $\begin{array}{c}\text { Noble Gas Mass } \\
\text { Spectrometry (NGMS) }\end{array}$ & SOP-UGTA-121 & The Analysis of ${ }^{3} \mathrm{H}$ and Dissolved Noble Gases in Groundwater & 3 & Copper tube & & \multirow[b]{2}{*}{ Indefinite } & & $\mathrm{NA}$ & & & & $\mathrm{NA}$ \\
\hline${ }_{3 \mathrm{H}}$ & $\begin{array}{l}\text { Liquid Scintillation } \\
\text { Counting (LSC) }\end{array}$ & $\begin{array}{l}\text { SOP-UGTA-110 } \\
\text { SOP-UGTA-131 }\end{array}$ & 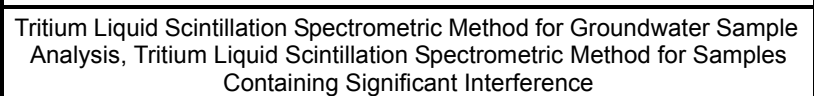 & 1 & Glass & & & & $\begin{array}{l}\text { Interlaboratory } \\
\text { comparison }\end{array}$ & & & & NIST SRM 4361-B-72 \\
\hline & & & & U.S. Gec & ological Survey & & & & & & & & \\
\hline $\begin{array}{l}\text { Metals/Trace } \\
\text { Elements }\end{array}$ & ICP-MS & YMPB-USGS-GCP-38 & Determination of Chemical Composition by ICP-MS & & & & 6 months & & $\begin{array}{l}\text { USGS Round } \\
\text { Robin }\end{array}$ & $\begin{array}{l}\text { Dependent } \\
\text { on specific } \\
\text { PEP results }\end{array}$ & & & NIST SRM 1643 \\
\hline${ }^{8786} \mathrm{Sr}$ & TIMS & USGS-DRIL-Sr & $\begin{array}{l}\text { Rb-Sr Isotope Geochemistry, } \\
\text { Determination of Chemical Composition by ICP-MS } \\
\end{array}$ & & & & & & & \pm 0.0005 & & & $\begin{array}{l}\text { NIST SRM 987; } \\
\text { Seawater Sr }\end{array}$ \\
\hline${ }^{234 / 238 \mathrm{U}}$ & Isotope dilution - TIMS & USGS-DRIL-U & $\begin{array}{l}\text { U-Th Disequilibrium Studies, } \\
\text { Determination of CCemical Composition by ICP-MS }\end{array}$ & 2 & $\begin{array}{l}\text { precleaned by acid } \\
\text { rinse }\end{array}$ & None & Indefinite & Filtered & $\begin{array}{l}\text { Interlaboratory } \\
\text { comparison }\end{array}$ & \pm 0.3 & Duplicates & $\begin{array}{l}\text { comparison and } \\
\text { NIST Standards }\end{array}$ & $\begin{array}{l}\text { NIST SRM 4321 } \\
\text { NIST U500; } \\
\text { secular equiliurium } \\
\text { uranium ore }\end{array}$ \\
\hline${ }^{34 \mathrm{~S}}$ & $\begin{array}{l}\text { Gas-flow isotope ratio } \\
\text { mass spectrometry }\end{array}$ & USGS-DSIL-S & Sulfur Isotope Analysis of Dissolved Sulfate in $\mathrm{H}_{2} \mathrm{O}$ & & & & & & & TBD & & & $\begin{array}{l}\text { IAEA-SO-5 } \\
\text { IAEA-SO-6 } \\
\text { NIST SRM 127 }\end{array}$ \\
\hline
\end{tabular}


Table 2-1

Groundwater Characterization Parameters

(Page 3 of 3 )

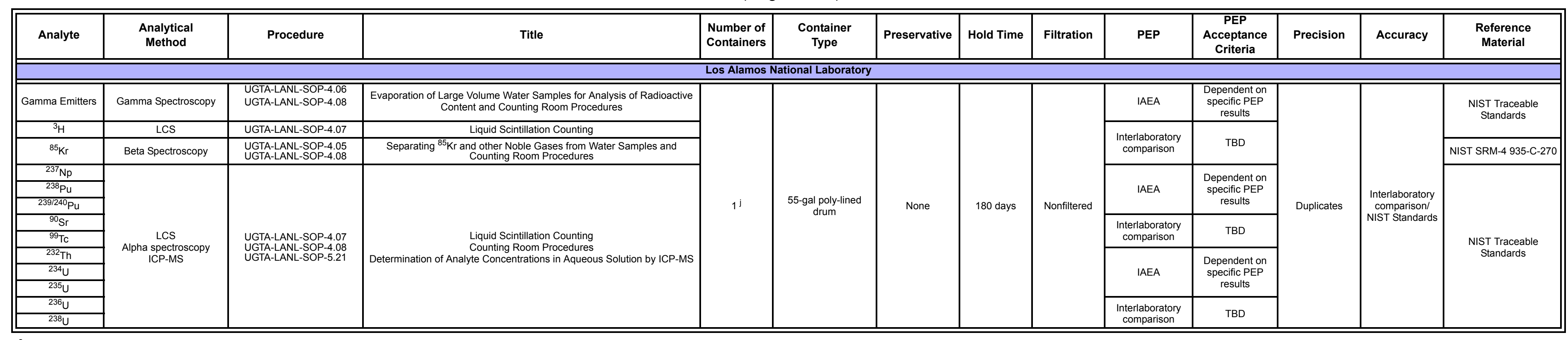

aEPA, 2011
$b$ Sample volume for discrete bailer samples

IEPA, 1980

A ASTM, 2000
DOE, 1997

AATMM, 2002
isome hot wells may require the collection of three 55 -gal drums.

$\mathrm{AgNO}_{3}=$ Silver nitrate

$\mathrm{NaOH}=$ Sodium hydroxide

DIC $=$ Dissolved inorganic carbo

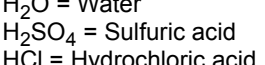

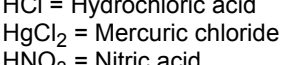

$\begin{array}{ll}= & \text { lodine } \\ K \mathrm{r}=\text { Krypton } & \end{array}$

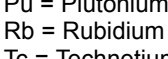

TC = Technetium
TDIC $=$ Total dissolved inorganic carbo
TDOC $=$ Total d dissolved organic carbon

Th $=$ Thorium
TOC = Total organic carbon

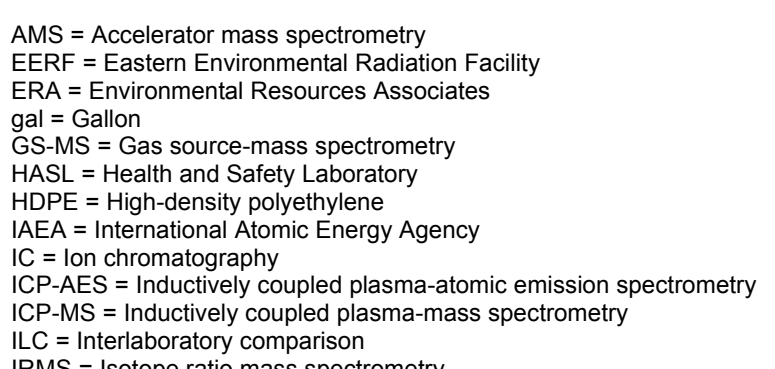

ICP-AES = Inductively coupled plasma-atomic emission spectrometry
ICP-SS

ILC $=$ Interlaboratory comparison
IRMS $=$ Isotope ratio mass spectrometry
$L=L$ Liter
MAPEP $=$ Mixed Analyte Performance Evaluation Program

$M L=$ Minliliter
$\mathrm{NA}=$ Not avalable

NGMS = Noble gas mass spectrometry

NSF $=$ National Science Foundation
PIMMS = Plasma ionization multicollector mass spectrometer

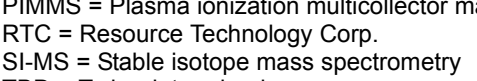

I D $=$ To be determined
TIMS $=$ Thermal ionization mass spectrometry
S

MIS $=$ Thermal ionization mass spectrometry
UNR $=$ University of Nevada Reno 
Table 2-2

Radioisotopes Potentially Selected as Contaminants of Concern and Analyzed by a Certified Laboratory

\begin{tabular}{|c|c|c|c|c|}
\hline Analyte & Abbreviation & Method $^{\mathrm{a}}$ & $\begin{array}{c}\text { Minimum } \\
\text { Detectable } \\
\text { Concentration } \\
(p C i / L)\end{array}$ & $\begin{array}{c}\text { Maximum } \\
\text { Contaminant } \\
\text { Level } \\
(\mathrm{pCi} / \mathrm{L})\end{array}$ \\
\hline Americium-241 & ${ }^{241} \mathrm{Am}$ & \multirow{2}{*}{$\begin{array}{c}\text { HASL } 300 \\
\text { Am-03-RC/Am-01-RC }{ }^{\mathrm{b}} \\
\left(\text { EPA } 901.1^{\mathrm{c}}\right)\end{array}$} & $\begin{array}{c}0.1 \\
(10)\end{array}$ & \multirow[t]{2}{*}{15} \\
\hline Americium-243 & ${ }^{243} \mathrm{Am}$ & & 1 & \\
\hline Carbon-14 & ${ }^{14} \mathrm{C}$ & EERF C-01 ${ }^{d}$ & 500 & $2,000^{\mathrm{e}}$ \\
\hline Cesium-135 & ${ }^{135} \mathrm{Cs}$ & Lab Specific $^{f}$ & NA & \multirow{2}{*}{$200^{e}$} \\
\hline Cesium-137 & ${ }^{137} \mathrm{Cs}$ & EPA $901.1^{c}$ & 10 & \\
\hline Chlorine-36 & ${ }^{36} \mathrm{Cl}$ & Lab Specific $^{f}$ & 4 & $700^{e}$ \\
\hline Curium-244 & ${ }^{244} \mathrm{Cm}$ & EPA $901.1^{c}$ & 10 & 15 \\
\hline Europium-150 & ${ }^{150} \mathrm{Eu}$ & Lab Specific $^{f}$ & NA & \multirow{3}{*}{$200^{e}$} \\
\hline Europium-152 & ${ }^{152} \mathrm{Eu}$ & \multirow{3}{*}{ EPA $902.0^{\circ}$} & \multirow{3}{*}{10} & \\
\hline Europium-154 & ${ }^{154} \mathrm{Eu}$ & & & \\
\hline lodine-129 & 129 & & & $1^{\mathrm{e}}$ \\
\hline Neptunium-237 & ${ }^{237} \mathrm{~Np}$ & \multirow{2}{*}{ Lab Specific $^{f}$} & \multirow{2}{*}{ NA } & 15 \\
\hline Nickel-59 & ${ }^{59} \mathrm{Ni}$ & & & \multirow{2}{*}{$50^{e}$} \\
\hline Nickel-63 & ${ }^{63} \mathrm{Ni}$ & CHEM-TP-NI ${ }^{9}$ & 10 & \\
\hline Plutonium-238 & ${ }^{238} \mathrm{Pu}$ & \multirow{3}{*}{$\begin{array}{c}\text { HASL } 300 \\
\text { Pu-10-RC/Pu-02-RC }\end{array}$} & \multirow{2}{*}{0.1} & \multirow{2}{*}{15} \\
\hline Plutonium-239/240 & ${ }^{239 / 240} \mathrm{Pu}$ & & & \\
\hline Plutonium-241 & ${ }^{241} \mathrm{Pu}$ & & 20 & $300^{\mathrm{e}}$ \\
\hline Plutonium-242 & ${ }^{242} \mathrm{Pu}$ & \multirow{2}{*}{ Lab Specific ${ }^{f}$} & \multirow{2}{*}{ NA } & 15 \\
\hline Samarium-151 & ${ }^{151} \mathrm{Sm}$ & & & $1,000^{\mathrm{e}}$ \\
\hline Strontium-90 & ${ }^{90} \mathrm{Sr}$ & EPA $905.0^{c} / S r-02-R^{b}$ & 1 & $8^{\mathrm{e}}$ \\
\hline Technetium-99 & ${ }^{99} \mathrm{Tc}$ & Lab Specific $^{f}$ & 10 & $900^{\mathrm{e}}$ \\
\hline Thorium-232 & ${ }^{232} \mathrm{Th}$ & HASL $300^{\mathrm{b}}$ & 0.2 & 15 \\
\hline Tritium & ${ }^{3} \mathrm{H}$ & EPA $906.0^{c} /$ Lab Specific $^{f}$ & 400 & $20,000^{\mathrm{e}}$ \\
\hline Uranium-234 & ${ }^{234} \mathrm{U}$ & \multirow{3}{*}{ HASL 300 U-02-RC ${ }^{b}$} & \multirow{3}{*}{0.1} & \multirow{3}{*}{$30 \mu \mathrm{g} / \mathrm{L}$} \\
\hline Uranium-235 & ${ }^{235} \mathrm{U}$ & & & \\
\hline Uranium-238 & ${ }^{238} \mathrm{U}$ & & & \\
\hline Zirconium-93 & $\overline{93} \mathrm{Zr}$ & Lab Specific $^{f}$ & NA & $2,000^{\mathrm{e}}$ \\
\hline
\end{tabular}

a Procedure modifications may be used.

${ }^{\mathrm{b}} \mathrm{DOE}, 1997$

${ }^{\circ} \mathrm{EPA}, 1980$

dEPA, 1984

e Activity concentrations equal to 4-millirem-per-year dose.

${ }^{f}$ The most current EPA, DOE, or equivalent accepted analytical method may be used

${ }^{9}$ DOE, 1999

$\mathrm{NA}=$ Not available

$\mu \mathrm{g} / \mathrm{L}=$ Micrograms per liter

Note: Radionuclides with no SDWA activity to dose factor (argon-39, calcium-41, cadmium-113m, krypton-85, niobium-94 palladium-107, tin-121m/126, and holmium-166); that are naturally abundant (potassium-40); or have a low inventory (aluminum-26 and niobium-93m) are not included in this list. 
Table 2-3

Fluid Management Sample Analytes

\begin{tabular}{|c|c|c|c|c|}
\hline \multirow[t]{2}{*}{ Analyte } & \multirow[t]{2}{*}{$\begin{array}{c}\text { Analytical } \\
\text { Method }\end{array}$} & \multirow[t]{2}{*}{$\begin{array}{l}\text { Reporting } \\
\text { Limit }\end{array}$} & \multicolumn{2}{|c|}{$\begin{array}{c}\text { Maximum } \\
\text { Contaminant } \\
\text { Level }\end{array}$} \\
\hline & & & RCRA & SDWA \\
\hline $\begin{array}{l}\text { Total Metals: } \\
\text { Arsenic } \\
\text { Barium } \\
\text { Cadmium } \\
\text { Chromium } \\
\text { Lead } \\
\text { Selenium } \\
\text { Silver }\end{array}$ & SW-846-6010 a & $\begin{array}{l}0.01 \mathrm{mg} / \mathrm{L} \\
0.1 \mathrm{mg} / \mathrm{L} \\
0.005 \mathrm{mg} / \mathrm{L} \\
0.01 \mathrm{mg} / \mathrm{L} \\
0.003 \mathrm{mg} / \mathrm{L} \\
0.005 \mathrm{mg} / \mathrm{L} \\
0.01 \mathrm{mg} / \mathrm{L}\end{array}$ & $\begin{array}{l}5.0 \mathrm{mg} / \mathrm{L} \\
100 \mathrm{mg} / \mathrm{L} \\
1.0 \mathrm{mg} / \mathrm{L} \\
5.0 \mathrm{mg} / \mathrm{L} \\
5.0 \mathrm{mg} / \mathrm{L} \\
1.0 \mathrm{mg} / \mathrm{L} \\
5.0 \mathrm{mg} / \mathrm{L}\end{array}$ & $\begin{array}{l}0.01 \mathrm{mg} / \mathrm{L} \\
2.0 \mathrm{mg} / \mathrm{L} \\
0.005 \mathrm{mg} / \mathrm{L} \\
0.1 \mathrm{mg} / \mathrm{L} \\
0.015 \mathrm{mg} / \mathrm{L} \\
0.05 \mathrm{mg} / \mathrm{L} \\
0.1 \mathrm{mg} / \mathrm{L}\end{array}$ \\
\hline Mercury & SW-846-7470 ${ }^{a}$ & 0.0002 mg/L & $0.2 \mathrm{mg} / \mathrm{L}$ & $0.002 \mathrm{mg} / \mathrm{L}$ \\
\hline $\begin{array}{l}\text { Dissolved Metals: } \\
\text { Arsenic } \\
\text { Barium } \\
\text { Cadmium } \\
\text { Chromium } \\
\text { Lead } \\
\text { Selenium } \\
\text { Silver }\end{array}$ & SW-846-6010 a & $\begin{array}{l}0.01 \mathrm{mg} / \mathrm{L} \\
0.2 \mathrm{mg} / \mathrm{L} \\
0.005 \mathrm{mg} / \mathrm{L} \\
0.01 \mathrm{mg} / \mathrm{L} \\
0.003 \mathrm{mg} / \mathrm{L} \\
0.005 \mathrm{mg} / \mathrm{L} \\
0.01 \mathrm{mg} / \mathrm{L}\end{array}$ & $\begin{array}{l}5.0 \mathrm{mg} / \mathrm{L} \\
100 \mathrm{mg} / \mathrm{L} \\
1.0 \mathrm{mg} / \mathrm{L} \\
5.0 \mathrm{mg} / \mathrm{L} \\
5.0 \mathrm{mg} / \mathrm{L} \\
1.0 \mathrm{mg} / \mathrm{L} \\
5.0 \mathrm{mg} / \mathrm{L}\end{array}$ & $\begin{array}{l}0.01 \mathrm{mg} / \mathrm{L} \\
2.0 \mathrm{mg} / \mathrm{L} \\
0.005 \mathrm{mg} / \mathrm{L} \\
0.1 \mathrm{mg} / \mathrm{L} \\
0.015 \mathrm{mg} / \mathrm{L} \\
0.05 \mathrm{mg} / \mathrm{L} \\
0.1 \mathrm{mg} / \mathrm{L}\end{array}$ \\
\hline Mercury & SW-846-7470 ${ }^{a}$ & 0.0002 mg/L & $0.2 \mathrm{mg} / \mathrm{L}$ & $0.002 \mathrm{mg} / \mathrm{L}$ \\
\hline Gross Alpha & b & $10 \mathrm{pCi} / \mathrm{L}$ & $\mathrm{N} / \mathrm{A}$ & $15 \mathrm{pCi} / \mathrm{L}$ \\
\hline Gross Beta & L & $<15 \mathrm{pCi} / \mathrm{L}$ & $\mathrm{N} / \mathrm{A}$ & $50 \mathrm{pCi} / \mathrm{L}$ \\
\hline Tritium & EPA $906.0^{b}$ & $1,000 \mathrm{pCi} / \mathrm{L}$ & N/A & $20,000 \mathrm{pCi} / \mathrm{L}$ \\
\hline
\end{tabular}

a EPA, 2011

${ }^{b}$ EPA, 1980

$\mathrm{N} / \mathrm{A}=$ Not applicable 
Table 2-4

\section{Nonregulated Analytes Used for Estimating the Origin, Pathway, and Timescale of Groundwater Flow and Transport}

(Page 1 of 2)

\begin{tabular}{|c|c|c|c|}
\hline Parameter & $\begin{array}{l}\text { Responsible } \\
\text { Organization }\end{array}$ & $\begin{array}{l}\text { Geochemical Processes } \\
\text { Controlling Distribution }\end{array}$ & $\begin{array}{l}\text { Hydrochemical Process Driving } \\
\text { Geochemical Response }\end{array}$ \\
\hline $\begin{array}{l}\text { Calcium, } \\
\text { Potassium, } \\
\text { Sodium, } \\
\text { Magnesium }\end{array}$ & $\begin{array}{l}\text { LLNL, } \\
\text { ER Contractor }\end{array}$ & $\begin{array}{l}\text { Dissolution and/or precipitation of aquifer } \\
\text { minerals, evapoconcentration, changes in } \mathrm{pH}\end{array}$ & \multirow{2}{*}{$\begin{array}{l}\text { Groundwater recharge or discharge (accompanied by } \\
\text { atmospheric interaction and/or evapoconcentration), groundwater } \\
\text { interaction with aquifer medium having distinct bulk chemistry, } \\
\text { presence of or mixing with chemically distinct water types }\end{array}$} \\
\hline $\begin{array}{l}\text { Chloride, } \\
\text { Sulfate }\end{array}$ & $\begin{array}{l}\text { LLNL, } \\
\text { ER Contractor }\end{array}$ & $\begin{array}{l}\text { Water mass evolution (preservation or } \\
\text { mixing), dissolution and/or precipitation of } \\
\text { aquifer minerals, evapoconcentration }\end{array}$ & \\
\hline $\begin{array}{l}\text { Aluminum, } \\
\text { Iron }\end{array}$ & DRI & $\begin{array}{l}\text { Water mass evolution, dissolution and/or } \\
\text { precipitation of aquifer minerals, changes in } \\
\text { redox potential, changes in } \mathrm{pH}\end{array}$ & $\begin{array}{l}\text { Groundwater interaction with chemically distinct aquifer medium; } \\
\text { presence of or mixing with chemically distinct water masses, } \\
\text { including residual drilling fluids }\end{array}$ \\
\hline$\delta^{18} \mathrm{O}$ & $\begin{array}{l}\text { DRI, } \\
\text { LLNL }\end{array}$ & $\begin{array}{l}\text { Recharge elevation/temperature, water mass } \\
\text { evolution (preservation or mixing), } \\
\text { evaporative fractionation (water-rock } \\
\text { interaction at elevated temperatures) }\end{array}$ & $\begin{array}{c}\text { Distinct water sources (discriminator for water masses recharged } \\
\text { under distinct conditions), indicator for water-rock interaction at } \\
\text { elevated temperatures and evapoconcentration }\end{array}$ \\
\hline$\delta^{2} \mathrm{H}$ & $\begin{array}{l}\text { DRI, } \\
\text { LLNL }\end{array}$ & $\begin{array}{c}\text { Recharge elevation/temperature, water mass } \\
\text { evolution (preservation or mixing) } \\
\text { evaporative fractionation }\end{array}$ & $\begin{array}{l}\text { Distinct water sources (discriminator for water masses recharged } \\
\text { under distinct conditions), indicator for evapoconcentration }\end{array}$ \\
\hline$\delta^{13} \mathrm{C}$ & $\begin{array}{l}\text { DRI, } \\
\text { LLNL }\end{array}$ & $\begin{array}{l}\text { Dissolution of carbonate minerals, carbon } \\
\text { exchange with aquifer carbonate minerals, } \\
\text { oxidation of DOC, atmospheric interaction }\end{array}$ & $\begin{array}{c}\text { Tracer interaction between distinct carbon reservoirs } \\
\text { (atmospheric, biological, lithological); good indicator for } \\
\text { water-rock interaction processes involving carbonate rock } \\
\text { in southern Nevada; influences }{ }^{14} \mathrm{C} \text { based } \\
\text { water age/travel time estimates }\end{array}$ \\
\hline$\delta^{34} S$ & USGS & $\begin{array}{l}\text { Concentration and origin of } S \text { in soils and } \\
\text { aquifer rock, water mass evolution, changes } \\
\text { in redox potential }\end{array}$ & $\begin{array}{c}\text { Water/rock reactions along flow path with emphasis on changes } \\
\text { in redox potentials, presence or absence of sulfur-reducing } \\
\text { bacteria, mixing of distinct water masses }\end{array}$ \\
\hline
\end{tabular}


Table 2-4

\section{Nonregulated Analytes Used for Estimating the Origin, Pathway, and Timescale of Groundwater Flow and Transport \\ (Page 2 of 2)}

\begin{tabular}{|c|c|c|c|}
\hline Parameter & $\begin{array}{l}\text { Responsible } \\
\text { Organization }\end{array}$ & $\begin{array}{l}\text { Geochemical Processes } \\
\text { Controlling Distribution }\end{array}$ & $\begin{array}{l}\text { Hydrochemical Process Driving } \\
\text { Geochemical Response }\end{array}$ \\
\hline${ }^{87} \mathrm{Sr} /{ }^{86} \mathrm{Sr}$ & USGS/LLNL & $\begin{array}{l}\text { Evolution of groundwater during recharge } \\
\text { and flow through aquifer }\end{array}$ & $\begin{array}{c}\text { Dissolution of soil constituents, mixing of distinct water masses, } \\
\text { solubility of aquifer rock, or exchange of Sr between solid and } \\
\text { aqueous components }\end{array}$ \\
\hline${ }^{234} U /{ }^{238} U$ & USGS/LLNL & $\begin{array}{l}\text { Evolution of groundwater during recharge } \\
\text { and flow through aquifer }\end{array}$ & $\begin{array}{l}\text { Dissolution of soil components, mixing of distinct water masses, } \\
\text { chemical reactivity of aquifer rock and water-to-rock mass ratio, } \\
\text { change in redox conditions, flow-path length }\end{array}$ \\
\hline $\begin{array}{c}\text { Tritium } \\
\text { (Low Level) }\end{array}$ & LLNL & $\begin{array}{l}\text { Evolution (preservation or mixing) of distinct } \\
\text { water masses, gas exchange, } \\
\text { radioactive decay }\end{array}$ & $\begin{array}{l}\text { Indicator for recent recharge source, travel time/water age } \\
\text { (for fast-moving groundwater), presence of bomb-pulse related } \\
\text { recharge (nearing end of practical life, useful on the } \\
\leq 10^{2} \text { year timescale) }\end{array}$ \\
\hline $\begin{array}{l}{ }^{14} \mathrm{C} \\
(\mathrm{DIC})\end{array}$ & LLNL & $\begin{array}{l}\text { Dissolution of carbonate minerals, carbon } \\
\text { exchange with aquifer carbonate minerals, } \\
\text { microbial interaction, oxidation of DOC, gas } \\
\text { exchange, radioactive decay }\end{array}$ & $\begin{array}{c}\text { Travel time/water age (useful on the }<10^{5} \text { year timescale), } \\
\text { local recharge, test-related impact; most applicable as } \\
\text { environmental tracer at larger scales; indicator of underground } \\
\text { test products at local scales }\end{array}$ \\
\hline${ }^{14} \mathrm{C}$ & DRI & $\begin{array}{l}\text { Presence/degradation of organic matter in } \\
\text { the recharge zone, soil gas interaction, } \\
\text { dilution by sedimentary organic matter in the } \\
\text { aquifer, microbial interaction, oxidation of } \\
\text { DOC, radioactive decay }\end{array}$ & $\begin{array}{c}\text { Travel time/water age (useful on the }<10^{5} \text { year timescale), } \\
\text { local recharge; most applicable as environmental tracer } \\
\text { at larger scales }\end{array}$ \\
\hline${ }^{36} \mathrm{Cl}$ & LLNL & $\begin{array}{l}\text { Water mass evolution (preservation or } \\
\text { mixing), dissolution of chloride-bearing } \\
\text { minerals, atmospheric interaction/deposition, } \\
\text { rock type, duration of exposure during } \\
\text { weathering, radioactive decay }\end{array}$ & $\begin{array}{l}\text { Travel time/water age (useful on the }>10^{4} \text { year timescale), } \\
\text { indicator of recharge/water source (or possibly chloride source in } \\
\text { apparently very old groundwater), presence of bomb-pulse or } \\
\text { test-related chloride (particularly influenced by recharge occurring } \\
\text { during testing in the south Pacific); potentially useful supporting } \\
\text { indicator at all scales providing corroborative data are available }\end{array}$ \\
\hline
\end{tabular}

Source: Modified from Benedict et al., 2003 
ASTM, see ASTM International.

ASTM International. 2000. Standard Test Method for Strontium-90 in Water, ASTM D5811-00. West Conshohocken, PA.

ASTM International. 2002. Standard Test Method for Plutonium in Water, ASTM D3865-02. West Conshohocken, PA.

Benedict, F.C., Jr., T.P. Rose, J.M. Thomas, R. Waddell, and R. Jacobson. 2003. Geochemistry Technical Basis Document, DOE/NV/13609-34. Reno, NV, and Westminster, CO: GeoTrans Inc.; Livermore, CA: Lawrence Livermore National Laboratory; and Reno, NV: Desert Research Institute.

DOE, see U.S. Department of Energy.

EPA, see U.S. Environmental Protection Agency.

U.S. Department of Energy. 1997. The Procedures Manual of the Environmental Measurements Laboratory, HASL-300. 28th Ed., Vol. I. February. New York, NY.

U.S. Department of Energy, Radiological and Environmental Services Laboratory. 1999. RESL Technical Procedure CHEM-TP-Ni.1 Determination of ${ }^{64} \mathrm{Ni}$ in Water. As accessed at https://www.nemi.gov/apex/f?p=237:48:1994595624346593::NO/ on 23 March 2011.

U.S. Environmental Protection Agency. 1980. Prescribed Procedures for Measurement of Radioactivity in Drinking Water, EPA 600/4-80-032. Cincinnati, OH: Environmental Monitoring and Support Laboratory Office of Research and Development.

U.S. Environmental Protection Agency. 1983. Methods for the Chemical Analysis of Water and Wastes, EPA/600/4-79/020. Cincinnati, OH: Environmental Monitoring and Support Laboratory Office of Research and Development.

U.S. Environmental Protection Agency. 1984. Eastern Environmental Radiation Facility Radiochemical Procedures Manual, EPA 520/5-84-006. Montgomery, AL: Office of Radiation Programs, Eastern Environmental Radiation Facility (renamed the National Air and Radiation Environmental Laboratory [NAREL] in 1989).

U.S. Environmental Protection Agency. 1993. Determination of Inorganic Anions by Ion Chromatography, Method 300.0. Cincinnati, OH: National Exposure Research Library Office of Research and Development. 
U.S. Environmental Protection Agency. 2011. SW-846, Test Methods for Evaluating Solid Waste, Physical/Chemical Methods. As accessed at http://www.epa.gov/epawaste/hazard/testmethods/sw846 on 23 March. 


\section{Library Distribution List}

\section{$\underline{\text { Copies }}$}

Bill Wilborn

U.S. Department of Energy

National Nuclear Security Administration

Nevada Site Office

Environmental Restoration Division

P.O. Box 98518, M/S 505

Las Vegas, NV 89193-8518

Bimal Mukhopadhyay

U.S. Department of Energy

National Nuclear Security Administration

Nevada Site Office

Environmental Restoration Division

P.O. Box 98518, M/S 505

Las Vegas, NV 89193-8518

Environmental Management Records

U.S. Department of Energy

National Nuclear Security Administration

Nevada Site Office

Environmental Restoration Division

P.O. Box 98518, M/S 505

Las Vegas, NV 89193-8518

NNSA/NSO Read File

U.S. Department of Energy

National Nuclear Security Administration

Nevada Site Office

Environmental Restoration Division

P.O. Box 98518, M/S 161

Las Vegas, NV 89193-8518

Chris Andres

Nevada Division of Environmental Protection

2030 E. Flamingo Rd., Suite 230

Las Vegas, NV 89119

Greg Raab

Nevada Division of Environmental Protection

2030 E. Flamingo Rd., Suite 230

Las Vegas, NV 89119
2 hard copies w/electronic media

1 electronic media

1 hard copy w/electronic media
1 electronic media

1 hard copy 


\section{Library Distribution List}

$\underline{\text { Copies }}$

Nevada Division of Environmental Protection Files

2030 E. Flamingo Rd., Suite 230

Las Vegas, NV 89119

Chuck Russell

Desert Research Institute

755 E. Flamingo Rd., M/S 433

Las Vegas, NV 89119

Jenny Chapman

Desert Research Institute

755 E. Flamingo Rd., M/S 433

Las Vegas, NV 89119

Karl Pohlmann

Desert Research Institute

755 E. Flamingo Rd., M/S 433

Las Vegas, NV 89119

Ronald Hershey

Desert Research Institute

2215 Raggio Parkway

Reno, NV 89512

Matt Reeves

Desert Research Institute

2215 Raggio Parkway

Reno, NV 89512

Ken Ortego

National Security Technologies, LLC

P.O. Box 98521, M/S NLV082

Las Vegas, NV 89193-8521

Sig Drellack

National Security Technologies, LLC

P.O. Box 98521, M/S NLV082

Las Vegas, NV 89193-8521
1 electronic media

1 electronic media

1 electronic media

1 electronic media

1 electronic media

1 electronic media

1 electronic media

1 electronic media 


\section{Library Distribution List}

$\underline{\text { Copies }}$

Naomi Becker

1 electronic media

Los Alamos National Laboratory

Bikini Atoll Road, SM 30

Los Alamos, NM 87545

Ed Kwicklis

1 electronic media

Los Alamos National Laboratory

Bikini Atoll Road, SM 30

Los Alamos, NM 87545

David Finnegan

1 electronic media

Los Alamos National Laboratory

Bikini Atoll Road, SM 30

Los Alamos, NM 87545

Walt McNab

1 electronic media

Lawrence Livermore National Laboratory

7000 East Ave., L-231

Livermore, CA 94550-9698

Mavrik Zavarin

1 electronic media

Lawrence Livermore National Laboratory

7000 East Ave., L-231

Livermore, CA 94550-9698

Bonnie Thompson

1 electronic media

USGS WRD

160 N. Stephanie St.

Henderson, NV 89074-8829

Robert Graves

1 electronic media

USGS WRD

160 N. Stephanie St.

Henderson, NV 89074-8829 


\section{Library Distribution List}

\section{$\underline{\text { Copies }}$}

B. J. Rhodes

1 electronic media

USGS WRD

160 N. Stephanie St.

Henderson, NV 89074-8829

J.B. Paces

USGS CR RM GD

1 electronic media

6th Ave. and Kipling St.

Building 53, Ent. S1, MS 963

Denver Federal Center

Denver, CO 80225-0046

Sam Marutzky

Navarro-Intera, LLC

1 hard copy w/electronic media

c/o U.S. DOE

P.O. Box 98952

Las Vegas, NV 89193-8952

Jeff Wurtz

Navarro-Intera, LLC

1 hard copy

c/o U.S. DOE

P.O. Box 98952

Las Vegas, NV 89193-8952

Jeff Sanchez

Navarro-Intera, LLC

c/o U.S. DOE

P.O. Box 98952

Las Vegas, NV 89193-8952

Dan Neubauer

Navarro-Intera, LLC

1 hard copy

c/o U.S. DOE

P.O. Box 98952

Las Vegas, NV 89193-8952

Irene Farnham

1 hard copy

Navarro-Intera, LLC

c/o U.S. DOE

P.O. Box 98952

Las Vegas, NV 89193-8952

1 hard copy 


\section{Library Distribution List}

\section{$\underline{\text { Copies }}$}

Susan Krenzien

Navarro-Intera, LLC

c/o U.S. DOE

P.O. Box 98952

Las Vegas, NV 89193-8952

Milinka Watson-Garrett

Navarro-Intera, LLC

c/o U.S. DOE

P.O. Box 98952

Las Vegas, NV 89193-8952

Greg Ruskauff

Navarro-Intera, LLC

c/o U.S. DOE

P.O. Box 98952

Las Vegas, NV 89193-8952

John Hand

Navarro-Intera, LLC

c/o U.S. DOE

P.O. Box 98952

Las Vegas, NV 89193-8952

Bruce Crowe

Navarro-Intera, LLC

c/o U.S. DOE

P.O. Box 98952

Las Vegas, NV 89193-8952

Robert Andrews

Navarro-Intera, LLC

c/o U.S. DOE

P.O. Box 98952

Las Vegas, NV 89193-8952

Jeanne Wightman

Navarro-Intera, LLC

c/o U.S. DOE

P.O. Box 98952

Las Vegas, NV 89193-8952
1 hard copy w/electronic media

1 hard copy

1 electronic media

1 electronic media

1 electronic media

1 electronic media

1 hard copy 


\section{Library Distribution List}

\section{$\underline{\text { Copies }}$}

Raymond Keeler

1 electronic media

Navarro-Intera, LLC

c/o U.S. DOE

P.O. Box 98952

Las Vegas, NV 89193-8952

Matt Knop

1 electronic media

Navarro-Intera, LLC

c/o U.S. DOE

P.O. Box 98952

Las Vegas, NV 89193-8952

Central Files

1 electronic media

Navarro-Intera, LLC

c/o U.S. DOE

P.O. Box 98952

Las Vegas, NV 89193-8952 